Portland State University

PDXScholar

1990

\title{
Oregon's Cuban-American community : from revolution to assimilation
}

Richard Dellenback

Portland State University

Follow this and additional works at: https://pdxscholar.library.pdx.edu/open_access_etds

Part of the Latin American History Commons, and the Social History Commons Let us know how access to this document benefits you.

\section{Recommended Citation}

Dellenback, Richard, "Oregon's Cuban-American community : from revolution to assimilation" (1990). Dissertations and Theses. Paper 4046.

https://doi.org/10.15760/etd.5930

This Thesis is brought to you for free and open access. It has been accepted for inclusion in Dissertations and Theses by an authorized administrator of PDXScholar. Please contact us if we can make this document more accessible: pdxscholar@pdx.edu. 
AN ABSTRACT OF THE THESIS of Richard Dellenback for the Master of Arts in History presented 12 February 1990.

Title: Oregon's Cuban-American Community:

From Revolution to Assimilation.

APPROVED BY THE MEMBERS OF THE THESIS COMMITTEE:

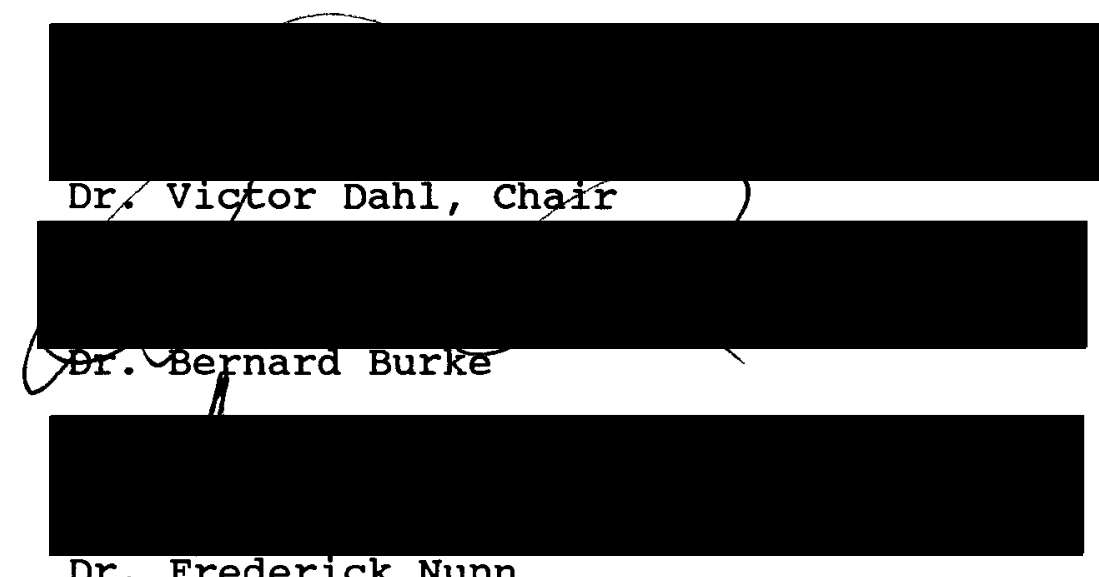

Dr. Frederick Nunn

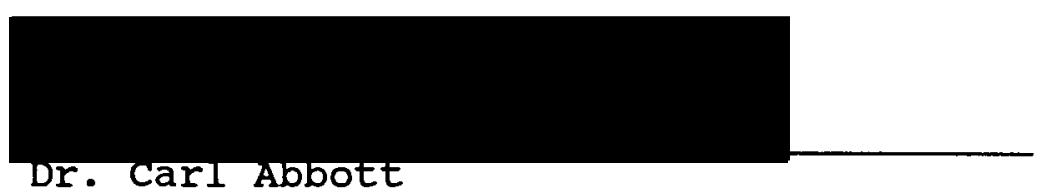

The adjustment and assimilation achieved by cubanAmericans who arrived in oregon during the 1960s was notable for its rapidity. Little contact existed between the state and the island prior to the resettlement efforts begun by the Charities Division of the Portland Catholic Archdiocese, where a group of concerned administrators meshed their activities 
with a nation-wide program created and encouraged by the United states government and private agencies.

More than one million Cubans departed their homeland for the United states during the decades following the Fidel Castro Revolution. Most of these refugees arrived in Miami, Florida, where a steadily increasing cuban community nurtured successive waves of arrivals, while simultaneously fostering economic and cultural linkages between Southern Florida and Latin America. This long-term process entailed immediate problems for the region, however, and a move to disperse the Cubans throughout the fifty American states ensued shortly after the arrival of the first major wave of immigrants.

The first chapter of the thesis details the "long count" historical process underlying the massive post-revolutionary influx, with special emphasis on salient aspects of the twentieth century relationship between the United states and Cuba. Chapters Two and Three discuss the nature of the migration and the response generated by American officials and private organizations. The remainder of the study seeks to synthesize commentaries and records pertaining to oregon's Cuban-American community. Chapter Four describes the emigres' arrival, while the fifth chapter develops the story of the state's response to this new presence. Chapter six examines the Cubans' speedy transition to integration, while the final chapter summarizes oral histories gathered during interviews with selected members of the community. 
For the Latin Americanist, the significant, distinctively Cuban cultural ambience that these immigrants fostered in oregon merits study and investigation, and this aspect of the research findings has been emphasized whenever possible. The regrettable loss of a conscious link to their cultural antecedents by successive generations constitutes a logical element of the thrust to achieve quick assimilation into the new environment. Many members of the Cuban-American community have achieved notable success in North America, although this outcome was not universal. The latter, by definition, is less amenable to record-keeping aimed at the long count, and also is less common in a peripheral area such as oregon. The thesis delineates this side of the migration's history. 


\section{OREGON'S CUBAN-AMERICAN COMMUNITY: \\ FROM REVOLUTION TO ASSIMILATION}

by

RICHARD DELLENBACK

A thesis submitted in partial fulfillment

of the requirements for the degree of

\section{MASTER OF ARTS}

in

HISTORY

Portland State University

1990 
TO THE OFFICE OF GRADUATE STUDIES:

The members of the Committee approve the thesis of Richard Dellenback presented 12 February 1990.

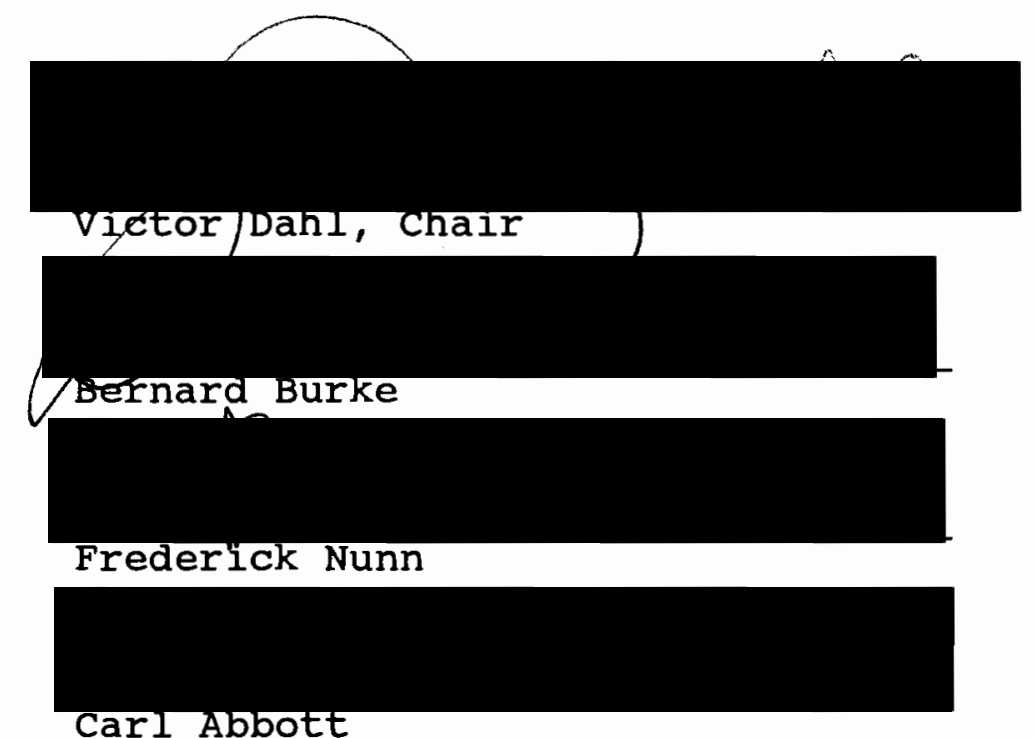

APPROVED:

Gernara Burke, Chalr, Department of History

c. William Savery, Interim Vice Provost for Graduate Studies and Research 
TABLE OF CONTENTS

PAGE

ACKNOWLEDGEMENTS ........................ ii

LIST OF TABLES....................... vi

CHAPTER

I CUBA AND THE UNITED STATES $\ldots \ldots \ldots \ldots \ldots \ldots \ldots \ldots$ BACKGROUND ISSUES AND MIGRATION

BEFORE THE REVOLUTION

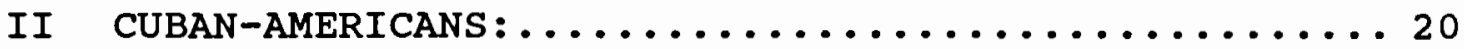
FROM THE REVOLUTION TO MARIEL

III CUBAN-AMERICANS :................... 45 MARIEL AND BEYOND

IV OREGON AND CUBA $: \ldots \ldots \ldots \ldots \ldots \ldots \ldots \ldots \ldots \ldots \ldots \ldots \ldots$ BACKGROUND AND EARLY ARRIVALS

V CUBAN-AMERICANS IN OREGON $\ldots \ldots \ldots \ldots \ldots \ldots \ldots \ldots 78$ THE STATE RESPONDS

VI OREGON'S CUBAN-AMERICANS :............... 93 EMERGENCE AND ASSIMILATION

VII OREGON'S CUBAN-AMERICANS : .............. 116 THE ORAL HISTORIES

REFERENCES CONSULTED........................ 134

ESSAY ON SOURCES . . . . . . . . . . . . . . . . . . 185

APPENDIX.................................. 191 


\section{ACKNOWLEDGEMENTS}

Love to my folks for their deep and ongoing support.

Muchas gracias to Portland state's excellent History Department for the first-rate instruction, especially señores Dahl, Nunn, and Burke.

Solid thanks to Diane and Lee for minimizing the system's bureaucratic hassles.

Gratitude to my cuban correspondents, and to a large group of excellent and very helpful archivists and librarians, especially Amy Dale and ILL at PSU (MB).

Appreciation to those two ex-roomies, and also to carlos and John, for the technical assistance.

Dedicated to Catherine, thanks for letting me see this thing in a more real perspective than would have been otherwise possible.

Nonetheless, the essay's shortcomings and blind spots are my very own. 


\section{LIST OF TABLES}

TABLE

PAGE

I Foreign-Born Whites, other American,

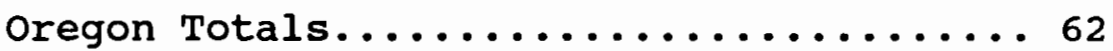

II Cuban Admissions by Place of Intended Residence, Oregon and Portland.........70

III Resettlement Figures for oregon 89

IV Naturalizations in Oregon of Cuban-Americans 110

V Oregon's Cubans: Residence by county

(Cuban-Born in Parenthesis) ........... 123

VI Persons of Cuban Birth and Parentage

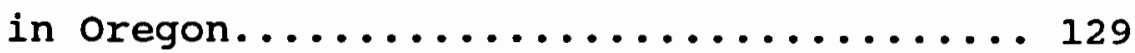

VII Cuban-Born and Year of Immigration 130 
CHAPTER I

CUBA AND THE UNITED STATES:

BACKGROUND ISSUES AND MIGRATION BEFORE THE REVOLUTION

The migration of over one million persons from Cuba to North America during the three decades after Fidel Castro came to power on the island in 1959 constituted an accelerated stage in a long-term process. Long before the Europeans arrived in the Caribbean at the end of the fifteenth century, there existed extensive commercial networks and the seasonal and permanent relocation of the region's indigenous peoples. In the keenest sense of the historical "long count," twentieth century population movements continued a process which has always marked human existence.

Emergence of the United States as a regional and then world power strongly influenced the direction and intensity of hemispheric population flows. Concrete economic and ideological configurations, especially anti-communism in the latter area, contributed to the previously unprecedented size of the movement that occurred in the aftermath of the cuban Revolution.

Oregon's participation in this aspect of the "long count," and indeed the state's connection to Cuba are of a 
much more recent order. oregon's small population and economic insignificance combined with geographic and cultural distance from the island to help maintain a nearly complete separation prior to the resettlements of the 1960 s. Fittingly, Oregon's Catholic Archdiocese, part of the institution that also long dominated the island's religious life, primarily facilitated the establishment of a small Cuban-American community in the state. The course that led these migrants to oregon influenced their 1 ife here, and helps explain their contribution to the state's make-up.

The archeological record is such that scholars are unlikely ever to settle definitively the precise sequence of the early migrations between the mainland of North America and the island. The Ciboney-Arawak presence on Cuba has been traced to both northerly and southerly origins. similarly, there is debate as to whether southern Florida's inhabitants at the time of the spaniards' arrival were refugees from ongoing struggles on the island, or were settlers from the north who later integrated into the larger caribbean trading $\operatorname{matrix} .1$

1 The preponderance of the modern evidence supports the notion that the movement was from the northern Amazon basin into the Caribbean. See Irving Rouse, Migrations in Prehistory (New Haven and London, 1986), chapter five, and Clark Wissler, The American Indian (Gloucester, Mass. , 1957), $\mathrm{p}$ 249. There are divergent views, however: $T$. D. Stewart, in The Peoples of America (New York, 1973), p 71, alludes to the possibility of a Florida origin for the ciboney, and in Florida: A Guide to the Southernmost state (New York, 1946), p 39, the Federal writers' Project work suggests that the Calusa in southwestern Florida possibly "were of Carib stock 
A long-term communication and movement between the island and the North American continent can be readily verified. As is true in every activity and era of human history, any analysis of the incentives for the various migrations must include economic, cultural, and political elements. A strict separation between and absolute ranking of such categories ignores the complexities of real-life decision-making situations.

Contacts continued after the conquest of the Caribbean islands and Mexico by the Europeans. Although only Hernando de soto among the early important Spanish explorers of Florida used Cuba as his base of operations, the island's increasing importance throughout the sixteenth century meant that it often served as the place of first refuge for remnants of various unsuccessful spanish forays into Southern North America. By century's end the spanish Florida and Georgia settlements depended on Havana for goods and services; even the Havana episcopal see oversaw church operations.2

Strategic considerations prompted the Spanish crown to utilize Havana's port as the nexus between the new and old

and had crossed from the islands to make a new home in Florida long before the coming of the white men." Other scholars adopt a more careful approach: see Raymond H. Thompson's introduction to Migrations in New world culture History (Tucson, 1958), and Gordon R. Willey, Archeology of Florida Gulf Coast (Cambridge, Mass., 1973) pp 570-574.

2 Charlton Tebeau, A History of Florida (Coral Gables, 1971), p 38 . 
worlds. The island sustained Spain's spiritual, economic and political presence in North America and most of their efforts on the continent, including the small colonizing migrations.

The English founding of Charleston, South Carolina, in 1670 proved a watershed event in marking the erosion of Spanish power in North America and growing Anglo-American preeminence. This new relationship also presaged Cuba's eventual orientation towards the United States and creation of an attractive economic and political magnet for the island's population. ${ }^{3}$ Spanish governors might be adept at organizing defenses at Saint Augustine, Florida, an imperial bastion since 1565, but political and economic momentum and the direction of the migratory flows emanated from the north. In this sense, the Treaty of Paris of 1763 that transferred Florida to British control completed a logical transition.

No important emigrations from Cuba into Florida occurred until British surrender of East Florida to the Spaniards at the conclusion of the American revolution. The second and final era of Spanish control began when Governor Vicente Manuel de Zéspedes departed from Havana for Saint Augustine on 19 June 1784. His politically significant arrival was not, however, a harbinger of Spanish resurgence. Rather, the

3 For a description of the early orientation of American merchants towards Cuban trade see Harry Bernstein, Origins of Inter-American Interest (Philadelphia, 1945), pp 22, 35-37, 89-91. The latter section contains Bernstein's compilation of relevant shipping figures. 
process of an inexorable movement from the north, constantly infringing on the decayed spanish system, reached another notable juncture with President James Monroe's proclamation of the Adams-Onis treaty on 22 February 1821, transferring sovereignty of Florida to the United States.

Cuba retained its strategic importance after the rest of Spanish America achieved independence. United States and European policy-makers alike maintained strong interests in controlling the Pearl of the Antilles, as mutual jealousies flourished. The best known early attempt to control the island ended with Secretary of state John Quincy Adams' successful deflection of British Foreign Minister George Canning's suggestion that the United states join in a proclamation disclaiming future ambitions on the island. Before finally following Adams' counsel, President Monroe consulted former Presidents Madison and Jefferson. Although concluding that the United states should accept Canning's proposal, Jefferson made clear his belief that "I candidly confess, that I have ever looked on Cuba as the most interesting addition which could ever be made to our system of states. 14

In a highly quotable letter to Hugh Nelson, United states Minister to Spain, Adams explicitly extended the "no-transfer"

4 The Writings of Thomas Jefferson Volume XV, (Washington, D.C., 1904), page 479. See also his letters to James Monroe dated 11 June 1823 and 23 June 1823. 
resolution to cuba. 5 He emphasized that "from their local position, (these islands) are natural appendages to the North American continent," and added:

it is scarcely possible to resist the conviction that the annexation of cuba to our federal republic will be indispensable to the continuance and integrity of the Union itself... But there are laws of political as well as of physical gravitation; and if an apple severed by the tempest from its native tree cannot choose but fall to the ground, Cuba, forcibly disjoined from its own unnatural connection with spain, and incapable of self-support, can gravitate only towards the North American Union, which by the same law of nature cannot cast her off from its bosom. 6

Concern about English and French intentions led American policy-makers to favor continued Spanish sovereignty in Cuba. Each administration in turn perceived Adams' law of "political gravitation" and acted patiently, relying on the security provided by a weak Spain. ${ }^{7}$ In 1848 , President James Polk

5 The resolution was passed by Congress on 15 January 1811 after transmission of a confidential message from President James Madison concerning British efforts in East Florida. Its intent was to block any attempted transfer of new world territory by European powers, thus expressing early United states Latin American policy in a manner similar to Jefferson's 1808 private message to Latin American agents, and anticipated the Monroe Doctrine.

6 Walter LaFeber, editor, John Quincy Adams and American Continental Empire (Chicago, 1965), pp 129-130.

7 According to Elbert $J$. Benton in International Law and Diplomacy of the Spanish-American War (Gloucester, Mass., 1908), pp 14-15. "Every Secretary of state during these years expressed in some form the national purpose to prevent the transfer to any other power." The footnote cites "Moore, Digest of International Law, Vol. VII, pp. 447ff. So Secretary Clay, 1825; Van Buren, 1829 ; Forsyth, 1840; Webster, 1843; Buchanan, 1848; Clayton, 1849; Marcy, 1853." 
offered to buy the island for $\$ 100,000,000$, the first of several such efforts. ${ }^{8}$ Escalating political tension on the island, dating from the early 1850 s filibustering expeditions, increasingly drew attention from both American policy-makers and the general public. The vehemence of these outcries reached a peak from 1895-1898 and played a traditional role in the politics of the period.

The gradual emergence of the United States as an economic and military power had profound impact on the people of cuba. Economic and political factors alike lured cubans to the mainland, but high United states tariffs provided the incentive that induced Cuban cigar manufacturers to move their operations to Key west in the 1830s. Skilled laborers followed, thus creating the first cuban enclave in Florida.' Movement prior to the 1860s, however, was on a small scale, and it is likely that less than 1,000 migrants, mostly white

8 See Allan Nevins, editor, The Diary of a President. 1845-1849 (New York, 1968), p 326, and also John Basset Moore, editor, The Works of James Buchanan (New York, 1960), pp 9496. Another publicized effort was the Ostend Manifesto, whose signatories included Buchanan, but which was rejected by President Pierce. Felix Roberto Masud-Piloto, With open Arms (Totowa, New Jersey, 1988), p 10, cites at least four such occasions, and, note 11 directs attention to James $\mathrm{w}$. Cortada, "Florida's Relations with Cuba During the Civil War," Florida Historical Quarterly 59 (July 1980): 52; Julio LeRiverend, Breve historia de Cuba (Havana, 1978); Emilio Roig de Leuchsenring, cuba no debe su independencia a los Estados Unidos (Havana, 1950); Philip S. Foner, The Spanish-CubanAmerican War and the Birth of American Imperialism, 2 Volumes (New York, 1972); and also Foner, A History of Cuba and Its Relations with the United States, 2 Volumes (New York, 1962).

9 Masud-Piloto, p 8 . 
and middle class, resided in the United States. By the mid1870s a more diversified group of about 12,000 had arrived, while large-scale immigration dated from the $1880 \mathrm{~s}^{10}$ The economic dimension of early cuban northward migration owed much to Vicente Martinez Ybor, a Spanish cigar manufacturer, who moved his operation from Havana to Key West in 1869, and from there to Tampa in 1885. Both transactions led to formation of large cuban communities, as rival firms quickly entered into the competition.

From their inception these communities developed a lively political life, a process that the 1868 outbreak of the Ten Years' War accelerated. ${ }^{11}$ The insurrection heightened the explicitly political dimension of the population flow to the mainland, and the chaos that prevailed from 1878 until fighting renewed in 1895 discouraged the emigres from returning home. At least 100,000 Cubans left the island from

10 Gerald E. Poyo, "With all, and for the good of all." The Emergence of Popular Nationalism in the Cuban Communities of the United States, 1848-1868 (Durham, 1989), pp 42-43.

11 Masud-Piloto, pp 8-11. See also Gerald E. Poyo, "Key West and the Cuban Ten-Year War," Florida Historical Quarterly, 57 (January 1979), p 289-305, and Poyo, "Cuban Revolutionaries and Monroe County Reconstruction Politics, 1868-1876," Florida Historical Quarterly, 55 (April 1977), pp 408-409. José Rivero Múniz, The Ybor City Story, translated by Eustasio Fernández and Henry Beltran (Tampa, Florida), contains an interesting first-hand description of the early days in ybor city, with especial concentration on José Martís visits. 
1868 to the end of the century. ${ }^{12}$

The exile community's political sensitivity prior to independence paralleled more recent arrivals' attitudes. Exile leaders of the 1880s, principally José Martí, reinvigorated the New York-based Junta that had been formed in November, 1867. There is substantial evidence of the Junta's effort to generate North American support for the war against spain. The numerous enclaves played a vital role in helping the exile revolutionary leadership to prepare for the new round of fighting. ${ }^{13}$

Near unanimity on the issue of expelling forever the

12 Louis A. Pérez, Cuba: Between Reform and Revolution (New York and Oxford, 1988), p 136.

13 In addition to Rivero Muniz see the unpublished Doctoral Dissertations of Marshall MacDonald True, Revolutionaries in Exile: The Cuban Revolutionary Party, 18911898 (University of Virginia, 1965); and Carol Ann Preece, Insurgent Guests: The Cuban Revolutionary Party and its Activities in the United States, 1892-1898 (Georgetown University, 1975). Further discussion is contained in articles written by Raymond $A$. Detter, "The Cuban Junta and Michigan: 1895-1898," in Michigan History, Volume 48, 1964, pp 35-46; George W. Auxier, "The Propaganda Activities of the Cuban Junta in Precipitating the Spanish-American War, 1895$1898, "$ in The Hispanic American Historical Review, 19 (1939), pp 268-305, and T. C. Appel, "The Unionization of Florida Cigarmakers and the coming of the War with spain, in The Hispanic American Historical Review 36 (1956), pp 38-49. There are also excellent frameworks of discussion provided by Louis Pérez in Cuba Between Empires: 1878-1902 (Pittsburgh, 1983); Louis Pérez, Cuba. Between Reform and Revolution (New York and Oxford, 1988); and in Philip S. Foner, A History of Cuba and its relations with the United states, Volume II, 1845-1895, (New York, 1963). The Cuban impact in shaping American policy towards intervention was not large, but the financial support and other efforts put forth by the community were notable relative to the number of Cubans living in North America. 
Spaniards had been building for a long time, as previous generations had gradually begun to articulate the possibility of severing colonial ties. Annexation to the United states remained a popular solution, even though the expatriates' enthusiastic response to the entreaties of José Marti and other Cuba Libre leaders reflected a deep and natural love of la patria. ${ }^{14}$ Marti and the chief revolutionary military leaders, Maxímo Gómez and Antonio Maceo, rejected annexation and were clear about their perception of the dangers of North American intervention. Newly arrived emigres fueled the nationalist ideal and lent strong support to Martís radical social views. With Marti's death the civilian and financial leaders within the Cuban polity, almost without exception, favored reliance on the United States, and deemphasized the social agenda. This factor certainly facilitated installation of a North American hegemony that prevailed during the first half of the twentieth century.

The island's devastated economy contrasted starkly with the development and growing opportunities offered in North America, giving many patriotic emigres a difficult choice:

When cuba finally gained its independence in 1898,

14 See Gerald Poyo's excellent book-length study of the changing nature of Cuban emigre perception during the period. The annexationist viewpoint, vital prior to the Ten Years' War, gave way rather quickly to the notion of independence from both spain and the United states. Conservative Junta leaders kept the annexationist dream dimly alive before Marti's emergence, thus their reversion to moderate positions after Marti's death demonstrated continuity with earlier elite thinking. 
many who had been living in exile in the United states and Europe returned home. For tens of thousands of others, however, the decision was not as easy. Many had been in exile for more than twenty years, and for them Key West, Tampa or New York was home.

Throughout the twentieth century, the existence of these communities, the economic attractions on the mainland, and the prospect of a haven for political opponents drew a steady, though small stream of people to the United States. Over the years various presidential regimes--especially those of Gerardo Machado, Dr. Ramón Grau San Martín, Carlos Prío Socorrás, and Fulgencio Batista--provoked an exodus. Political considerations were often paramount in these migrations. ${ }^{16}$ Thus, what was unusual was not that migration occurred, but that such large numbers departed to the United States after the fall of the Batista government to Fidel Castro's forces on New Years' Day in 1959.

Attitudes and actions of United states officials who dealt with Cuba prior to the 1890 s often revealed expectations that the island must eventually be acquired. Further, the official attitude nearly always advocated patient and careful

15 Masud-Piloto, p 11.

${ }^{16}$ Masud-Piloto, p 7. Robert L. Bach discusses the issue in depth in his article "The New Cuban Exodus: Political and Economic Motivations," in Caribbean Review (Winter 1982). On page 23 he mentions the Machado and Batista emigres, and finishes: "A. Jorge and R. Moncarz have argued, in fact, that the entire history of the cuban flow to the United states corresponds only to episodes of political upheaval and not to economic crises." 
methods. Indeed Cuba Libre's call for unequivocal independence, the rallying cry of the 1890 s revolutionaries which anticipated the twentieth century attitude, reflected a largely unexpressed and possibly unperceived goal on the part of Cubans for seventy years after the Spanish American wars for independence. ${ }^{17}$

After the Spanish-American war, the United states supplanted spain in cuba both politically and economically. Independence came after four years of United States army occupation, but the Platt Amendment, which became part of Cuba's organic law, limited the new nation's options:

Under the amendment cuba was forbidden to sign international treaties or lease military bases, except to the United States, and the United States reserved the right to intervene militarily in cuba for the preservation of Cuban independence, the maintenance of a government adequate for the protection of life, property, and individual liberty.

The political dimension of United states control, which included three military interventions, accompanied growing financial control of the Cuban economy. The dependency relationship went beyond these blatant interests to the less

17 This is important inasmuch as contemporary leftist analyses focusing on American avariciousness often contain an implied awareness of later attitudes. The reader is induced to contrast the words of past decision-makers with modern perceptions, and is led to see a continuous, almost conspiratorial thread tying U.S. policy-makers together, while simultaneously viewing a conflict between Anglo and Latin American attitudes that did not exist. 
quantifiable, but no less genuine realms of psychology and culture. Republican reliance on diplomacy in the 1920 s and Franklin Roosevelt's Good Neighbor Policy of the 1930s signalled shifts in style, not in substance.

The differences in the timing, sequence and pace of change that prevails in Latin America relative to the United States figures importantly in grasping the situation in Cuba. ${ }^{19}$ While North America participated in full-scale industrialization and modernization, Cuba, like the rest of Latin America, only slowly began to alter old modes. The resultant imbalance left cuba in a weak position in terms of controlling national resources. New perceptions about Latin America's situation, which laid the foundation for the revolutionary events later in the century, appeared in such works as Euclydes da Cunha's Rebellion in the Backlands and José Enrique Rodo's Ariel, and in the events of the Mexican Revolution. This new awareness was not yet manifest in Cuba, which exhibited a high degree of dependency on the United states.

By 12 August 1933, when the regime of General Machado

19 For the seminal application of contemporary relativism to Latin America see the first section of The Ideas and Doctrines of Victor Raúl Haya de la Torre, Selected, edited, and translated by Robert $J$. Alexander (The Kent University Press, 1973). Although a Peruvian, Haya was concerned with the implications of the difference between the rates of change in Latin America as compared to the developed world. His critique also has great utility in evaluating Marxist analyses of Latin American historical processes. 
fell of its own weight and from the pressure engendered by the changes in cuban society, a new factor, international communism, led by but not limited to the soviet Union, constituted an important element on the world stage. North American policy-makers readily engaged in fierce combat with this newly perceived threat to private American property interests, despite the fact that the Moscow-oriented Cuban Communist party, apart from some notable success on behalf of organized labor, played only a relatively minor role in the island's political and economic life. ${ }^{20}$

Communist influence remained small throughout the $1940 \mathrm{~s}$ and 1950s. To retain political control Batista, Grau, and Prio executed complicated maneuvers among the competing national interest groups, and each of them made concessions to and formed temporary alliances with the cuban communists. Even Machado offered a last minute deal to old communist adversaries in a vain attempt to save his presidency.

${ }^{20}$ For the best overview of the communist Party's history in Cuba see Andres Suárez, Cuba: Castroism and Communism, 1956-1966 (Cambridge and London, 1967). For material about of United States concerns, including Sumner Welles' visit with American businessmen located in Cuba, see Robert F. Smith, The United States and Cuba: Business and Diplomacy, 1917-1960 (New York, 1960), pp 148-149; also Irwin F. Gellman, Roosevelt and Batista: Good Neighbor Diplomacy in Cuba, 1933-1945 (Albuquerque, 1973), pp 35, 72, 91-116. Relevant state Department documents are included in Foreign Relations of the United States, 1933, Volume V, pp 412-415, also dispatches dated 13, 16, 20 September; 1, 4, 6, 7 October; 4 November; 14 December; Welles' address of 29 March 1934 in United States State Department Inter-American series, number $7 ;$ and the United States Foreign Policy Association's 1934 study of Cuba. 
Batista, who manipulated Cuban politics from 1933 to 1940, served as president from 1940 until 1944. His chief liberal opponents during this period were the Autenticos, led by $\mathrm{Dr}$. Ramón Grau San Martín. Batista proved adept at playing the communists off against this adversary, going so far as to place two party leaders in his cabinet as ministers without portfolios in March of 1943. After his election as president in 1944, Grau's short-lived rapprochement with the party provided Communist leaders with their final access to the legal mechanisms of state prior to the Revolution.

United states officials demonstrated concern with the dangers of communist influence in Cuba beginning in the 1920s, and assessments of Cuban Presidents continued to be based on the degree of anti-red virulence that each exhibited. Sumner Welles, who arrived to take his post as American Ambassador in May, 1933, provided clear expression of this theme. Policymakers' overreaction to the communist threat during the 1940 s and 1950s matched the Mccarthy-era obsession with the red menace, anticipating the official response to Castro's assumption of power. ${ }^{21}$

On 10 March 1952 Fulgencio Batista effectively engineered

21 Foreign Relations of the United States, 1947, Volume VIII: 29 March, 1 May, 17 June; 1948, Volume IX: 29 July; 1949, Volume II: 8 April, 14 April, 16 May, 24 May, 9 August; 1950, Volume II: 11 January 1951. 
a coup that returned the former Sergeant to the Presidential Palace.

The ease with which Batista and the army seized power...reflected considerably more than the adroit application of conspiratorial talents. The effects of nearly a decade of graft, corruption, and scandal at all levels of civilian government had more than adequately paved the way for the return of military rule in 1952.22

The old parties and leaders proved inadequate to the task of establishing a legitimate opposition to the new Batista, who now jettisoned that much of his previous efforts which had been devoted to genuine reform.

For the American elite matters in Cuba were simpler. Secretary of State Dean Acheson's memorandum to President Harry Truman dated 24 March 1952 discussed Batista's formal recognition request. The crux of the matter was the regime's "intention to take steps to curtail international communist activities in Cuba." After detailing recent anti-Soviet diplomatic moves, the author continued:

While Batista when President of Cuba in the early '40s tolerated Communist domination of the cuban Confederation of Workers, the world situation with regard to international communism has changed radically since that time, and we have no reason to believe that Batista will not be strongly antiCommunist.

The President accepted Acheson's recommendation of immediate

22 Pérez, Cuba: Between Reform and Revolution, p 289.

23 Foreign Relations of the United States, 1952-1954, Volume IV, p 871 . 
recognition.

Fidel Castro's spectacular attack on the Moncada Barracks on 26 July 1953 ignited the process which culminated in his assumption of power in January of 1959. He owed part of his triumph to the corruption of the old elites, while the accelerating pace of change in Latin America helped define popular Cuban disaffection with the Batista government.

After 1953 Eisenhower's Latin American policy:

was single-minded, according to one high-ranking State Department official: 'to keep the area quiet and keep communism out... [Secretary of state Dulles] was very tolerant, I think, of dictatorships so long
as they took a firm stand against communism. 24

Latin America figured only tangentially in Eisenhower administration thinking, and then only "in the context of 'the Cold War and Dulles' theory that we had to stop the advance of communism anywhere." 25 Batista's public posture coincided neatly with American policy makers' requirements, and Ambassador Arthur Gardner could be counted as one of Fulgencio Batista's best friends. Further, Cuba's relative prosperity appealed to legal concerns and criminal elements alike, and the island remained a safe haven for United states interests

24 Morris H. Morley, Imperial state and Revolution: The United state and Cuba, 1952-1986 (Cambridge, 1987), pp 42-43. Morley cites John Dreier interview, Washington D.C., May 24, 1965, The Dulles Oral History Collection, Princeton University Library, p 10 .

25 Morley, $p$ 42. The note cites "Personal Interview: Department of State official, Washington D.C., March 10, 1975. The respondent was a senior American representative to OAS during the 1950s." 
even after the landing of Fidel Castro and the crew of the Granma on 2 December 1956.

Ambassador Gardner's replacement, Earl E. T. Smith, who took his oath in June of 1957, opposed the communist menace no less stridently than had his predecessor. ${ }^{26}$ Nonetheless, the depth of the issues involved in the Cuban crisis of the 1950s went far beyond the Batista government's political inadequacies. ${ }^{27}$ Widespread belief that the only acceptable resolution involved profound socio-economic changes and/or the removal of the present government made the rebels' ultimate success apparent to nearly everyone by 1958. The American government's decision to impose an arms embargo in March of 1958 provided a vital step in collapsing the final hopes of Batista's supporters. The increased migration in 1958 and 1959 reflected this fact, and after 1959 a new stream began to flow.

At that juncture the international situation and the

${ }^{26}$ Earl E. T. Smith, The Fourth Floor. An account of the Castro Communist revolution (New York, 1962). See also Smith and Gardner testimony in "Communist threat to the U.S. through the Caribbean" hearings. Hearings before subcommittee to investigate the administration of the National security Act and other internal security laws of the committee on the Judiciary of the United States Senate, 27 August and 30 August 1960. For a more radical view of U.S. involvement, and one that dovetails nicely with the revelations about $1960 \mathrm{~s}$ activities as uncovered by the church investigation see warren Hinckle and William $W$. Turner in The Fish is Red (New York, 1981), pp 33, 50-59.

27 See Pérez's excellent synopsis of the relative decline that hit cubans during the decade, Cuba Between Reform and Revolution, pp 295-303. 
nature of the revolutionary cuban regime presented very different conditions from what had previously existed. The highly charged cold war anti-communist mentality then prevailing in the United states allowed, indeed almost demanded, that the government try to manage the situation in Cuba so as to forestall the communist menace. Meanwhile, Fidel Castro rode the crest of a different historical wave, that of the emerging Third World.

The precise course of Castro's decision to accept massive Soviet aid, and the path that led to his 2 December 1961 declaration that "I am a Marxist, and will be one until the day I die, "28 is beyond the scope of this study. However, the implications of those moves, and of the radical restructuring undertaken by the victors in the revolution spurred another, more massive exodus to the United states. It is the size of this movement, and not the migration itself that constituted the new element in Cuban-American relations. The maneuvering that ensued in the following three decades, and the implications for oregon will be investigated in subsequent sections. 
CHAPTER II

\section{CUBAN-AMERICANS : \\ FROM THE REVOLUTION TO MARIEL}

The influx of Cubans into the United States after 1959 opened the question as to whether to classify it as primarily a political or economic movement. Robert Bach, an authoritative observer of the various migration waves, has analyzed the tension between the two views, which emerged after the United States adopted the United Nations definition of refugees in the Refugee Act of 1980. This definition, "founded on universally acceptable humanitarian principles," was not compatible with United States policy, which made decisions about which refugees to accept on other grounds: "explicitly...those who flee from communist governments."1 The aftermath of the last major wave of Cuban migrants, those dubbed Marielitos, saw separate approaches taken to Cuban and Haitian arrivals, which brought the problem into the open.

In Bach's view, "the political and economic distinction is...clearly an outcome of an intellectual tradition of viewing migrations as individually motivated events." ${ }^{2}$ Such

1 Robert L. Bach, "The New Cuban Exodus," Caribbean Review, p 22.

2 Bach, "The New Cuban Exodus," p 22. 
neat categorization of individual motivations is not tenable and ignores, what is for Bach, the core of the issue:

complex matters of international and domestic politics and world economic problems that underlie expulsion, reception, and resettlement...the defining characteristics of migration flows are found at the level of social and economic organization and international politics, not among individual perceptions and motivations. 3

Thus, it is necessary to consider the ideological stance and practical situation in both the sending and receiving state involved in any particular migration flow.

In the case of those cubans who arrived in the United states after castro's assumption of power, the United statesCuba relationship, as modified by the cold war and especially the actions of the Soviet Union, has been the key factor in fixing migration rates and in establishing programs designed to facilitate the integration of the more than one million Cubans now living in the United States. From the American point of view, "Communism, Communist influence, and American economic interests were the real issues." ${ }^{4}$ Fidel Castro's chief concern, on the other hand, was the iron control exercised over Cuban affairs by the United states since 1898. The Soviet Union's active interest in establishing an American hemisphere outpost had to give way to the reality of American power and the need to move cautiously. The cuban-soviet

\footnotetext{
3 Bach, "The New Cuban Exodus," pp 22-23.

4 Masud-Piloto, p 21.
} 
connection formed slowly and carefully during the early years after the revolution, nurtured, in part, by the overreaction of American policy-makers, and influenced by the pervasive fear of the communist menace that gripped their government and nation.

Ex-President Batista's far-seeing or particularly wellplaced intimates and supporters who were well-situated financially left the island in 1958 or early 1959. They joined an estimated 30,000 paisanos in the United States, and were in turn supplemented by other groups as the years passed. ${ }^{5}$ Fidel's moves against the island's power structure advanced more rapidly than his acceptance of the increasingly necessary Soviet aid, as dispossessed and disillusioned groups of Cuban nationals fed the exodus to Florida. ${ }^{6}$ Groups departing before about October of 1960, included those adversely affected by the regime's land reform policies and some middle sector groups with ideological motivations. ${ }^{7}$

5 Alejandro Portes and Robert L. Bach, Latin Journey: Cuban and Mexican Immigrants in the United States (Berkeley, Los Angeles, London, 1985), p 84. Patrick Lee Gallagher, The Cuban Exile: A Socio-political Analysis (New York, 1980), p 1 , estimates that 3,000 such Batistianos arrived in the early months of 1959. Gallagher, page 35, places 20,000 expatriate Cubans in Miami at the time of Castro's takeover.

6 In February Castro consolidated his political power, in March a $50 \%$ rent reduction began the series of radical economic reforms, and on 3 June the Land Reform Law was promulgated.

7 Gallagher, p 38. Masud-Piloto, p 58, lists a figure of "only 10,000" between January 1959 and October 1960 . 
One scholar's description of "dazed, defeated, and depressed" arrivals, people most importantly distinguished by their expectation of a merely temporary exile, captured the essence of these early arrivals' viewpoints. 8 The increasing pace of revolutionary reforms on the island, widely felt economic hardships, and growing tension between the American and Cuban governments contributed to the migration's increasing flow, which totalled some 150,000 from January 1961 until the shutting down of emigration in the aftermath of the 1962 Missile Crisis. This latter group was more varied in its make-up, although it included large numbers of professionals and technicians, and increasingly, former castroites now soured on the course of the changes on the island. ${ }^{9}$ The relatively well-off and well-educated background of these early refugees was the most important factor in creating what came, in subsequent decades, to be widely regarded as a cuban success story. ${ }^{10}$ Later waves of immigrants, while more closely reflecting the make-up of the island's population, built on the efforts of these first arrivals.

${ }^{8}$ Eleanor Meyer Rogg, The Assimilation of Cuban Exiles: The role of community and class (New York, 1974), p 2 .

9 Masud-Piloto, p 58; Gallagher, p 39.

10 The articulation of Richard Fagan, Richard A. Brody, and Thomas O'Leary was often cited: Cubans in Exile: Disaffection and the Revolution (Palo Alto, 1968), p 23. "The great preponderance of the refugees are drawn from the wealthier, the better educated, the more urban, and the higher occupational sectors." 
A serious, major confrontation between American oil refineries and the Cuban government surfaced in June of 1960 . President Dwight Eisenhower's cancellation of Cuba's sugar quota in early July exacerbated the situation. on 5 August Castro responded by nationalizing all thirty-six Americanowned sugar mills, two oil refineries, and the utility companies. The American delegation to the Sixth and Seventh Meetings of Consultation of American Foreign Ministers at San José, Costa Rica severely lambasted Fidel and his regime in late August 1960. Then, too, hearings held by the Subcommittee on Inter-American affairs of the House Committee on Foreign Affairs, and by the Senate Judiciary Subcommittee in July--accompanied by a rhetorical offensive launched against Castro and American Cuban policy by the Democratic presidential nominee, Senator John Kennedy, on 24 August-indicated the virulence of American opinion. ${ }^{11}$

11 Hearings before the subcommittee to investigate the administration of the National security Act and other internal security laws of the Committee on the Judiciary of the United States senate, "Communist threat to the U.S. through the Caribbean." Subcommittee on Inter-American Affairs of the House Committee on Foreign Affairs, "The Communist Threat in Latin America." Report of U.S. Delegation to Sixth and Seventh Ministers' Meetings, state Department Inter-American Series, \#79. New York Times, 25 August 1960, p 20; 27 August $1960, \mathrm{pp} 1,29$ August 1960, p 1; 16 October 1960, p 52; 21 October 1960, p 1. See also Richard Nixon's version of Kennedy's use of the Cuban issue during the final debate between the two candidates: Readers' Digest, "Cuba, Castro, and John F. Kennedy," November, 1964, pp 283-300, and Six Crises (Garden City, New York, 1962), pp 354-355. The Six Crises version more clearly expressed Nixon's anger against Kennedy for using sensitive information about the already approved Bay of Pigs invasion plan against him. Nixon averred that his role as Vice-President left him defenseless to 
Meanwhile, the increasing number of cuban migrants arriving in Miami demanded the attention of local, state and Federal agencies. While local and state authorities began to feel pressure, the Eisenhower administration focused on long range possibilities. One writer contrasted the President's 17 March 1960 "dramatic plea to congress to accept more immigrants for 'humanitarian reasons," with "secret actions taken just a few hours before... in ordering the CIA to organize, arm, and train cuban exiles for a possible invasion of Cuba."12 This counter-stroke, although aimed at the perceived root cause of the migration, inadequately dealt with the immediate problems faced by the growing refugee community.

A Cuban Refugee Emergency Center opened in Miami in December 1960, and on 12 December the president allocated one million dollars for cuban refugee aid from his special contingencies fund. on 3 January 1961, shortly before Kennedy's inauguration, the United states broke diplomatic relations with cuba. In the aftermath of the break, Eisenhower's language took on a new tone that abandoned the humanitarian angle, and instead emphasized the immigrants' need to flee "communist oppression."13 This new articulation

retaliate without blowing the operation's cover, hence he was at pains to make the reader realize that he, Nixon, had as usual, opted for the moral high ground.

12 Masud-Piloto, p 34.

13 Masud-Piloto, p 34. 
continued to define the stance of the American government in subsequent years.

The Kennedy administration inherited an invasion plan formulated by Eisenhower policy-makers, and also received a refugee strategy. Tracy Voorhees, the former head of the Hungarian Refugee Program, which had been created at the time of the 1956 crisis, submitted his report on 18 January 1961. Voorhees' plan was based on that stint as head of the Hungarian refugee program. That migration had seen the arrival and rapid adjustment of some 38,000 refugees, most of whom possessed professional or otherwise valued skills. The Cuban model similarly imagined an orderly flow and quick resettlement of useful immigrants. Initial analyses trumpeted the financial help being provided by corporations such as Texaco, Ford, International Business Machines Corporation, the Rockefeller Foundation, and individuals such as Cardinal Francis spellman of New York City. ${ }^{14}$ Meanwhile, four organizations took the lead in the quickly developing plan to resettle the arrivals outside of the Miami area: the National Catholic Welfare Conference, Church World Service, the Hebrew Immigrant Aid Society, and the International Red Cross.

14 Department of State Bulletin, 9 January 1961, pp 4548; Charles Shreiner, America, 18 February 1961, pp 664-665. For the nine points contained in Voorhees' report see Department of state Bulletin, 20 February 1961, pp 256-257. Secretary of Health, Education, and Welfare Abraham Ribicoff was named to head the refugee effort. 
One result of this effort was the first numerically significant arrival of cubans in the state of oregon. A spontaneous decision by responsible figures in the oregon Catholic Archdiocese to expand the small resettlement program that had been developed in the 1950s, primarily to aid Dutch Indonesian refugees, brought the migration into the Portland metropolitan area.

Another notable aspect of the resettlement plan, which also included Oregon's participation, was the Cuban Children's Program, designed to provide care for unaccompanied adolescents whose parents were sending them away from the island, usually with the intention of a future family reunification, either in Cuba or, increasingly after the Bay of Pigs fiasco, in Miami. The roots of the scheme, which remained secret until March of 1962 , lay in a rumor that swept the island in 1960 claiming that the state intended to take control of the nation's children as part of the communist plan to create the new man. ${ }^{15}$

In the meantime, secret talks began between Monsignor Bryan 0 . Walsh and state Department officials, in an attempt to "save the children." out of those discussions came operation "Pedro Pan," designed to "help Cuban parents send their children unaccompanied to the United States to avoid

15 See Masud-Piloto's discussion, pp 39-41. The author mentions circulation of the proposed decree through the cuban underground and Castro's claim that the CIA was involved. 
communist indoctrination." The operation later evolved into the Cuban Children's Program.

concurrently with addressing the refugee problem, Kennedy's decision to allow the CIA-run invasion of Cuba to take place--as planned by the Eisenhower administration-proved an important event in Cuban-American relations and for the heightening exodus. A 1,500 man assault force, consisting chiefly of cuban exiles, landed on the island at the Bay of Pigs on 17 April 1961. Within seventy-two hours Cuban armed forces decisively defeated la brigada, as Brigade 2506 became known, captured the vast majority of the force, and jailed them. A twenty month period of intense political maneuvering followed. In exchange for fifty-three million dollars worth of food and medical supplies--including the tractors which eventually became the symbol of the deal--the cuban regime released 1,113 survivors (of 1,189 captured) thereby cementing the permanency of the Cuban migration as they returned to the United States mainland. Unwittingly perhaps, Fidel Castro set up the formidable opposition cadre with which he would have to deal during ensuing years.

16 Masud-Piloto, p 39. The citations are from Walsh's article in Journal of Interamerican studies and World Affairs, 3-4 (July-October 1971), p 389. Ten teenage boys, the first of 14,048, or 14,156 children--according to Michael J. McNally in Catholicism in South Florida, 1868-1968, (Gainesville, 1982), p 148--arrived in Miami on 26 December 1960. MasudPiloto makes use of the contemporary news reports which emphasized the anti-Communist brainwashing angle. See also New York Times, 8 December 1961, p 24, and 9 March 1963, p 1; U.S. News and World Report, 19 March 1962, p 16. 
The crushing nature of this failure forced an awareness of the probability of permanent exile into many refugees' minds. This marked a significant difference from the community's pre-Bay of Pigs mentality. Some of the exiles nonetheless remained adamant in their resistance to the Castro regime and to the threat of communism. The members of la brigada continued to play a central role in the political and psychological perceptions of the Cuban exiles. Seven hundred survivors entered the United states military, where many received special training which they have continued to use in the intervening decades. ${ }^{17}$ Indeed, the political life of the Cuban-American community strongly influenced relations between the two countries.

The September 1989 election of a Cuban-American woman, Ileana Ros-Lehtinen, to fill the seat of powerful Democrat Claude Pepper as a member of Congress from Miami, indicated the growing power of the Cuban community in southern Florida, reflected Cubans' concern with politics, and allowed Miami's Hispanics to demonstrate a significant degree of ethnic solidarity. ${ }^{18}$ The severe, and often extra-legal, efforts made by extremist cuban refugees against castro, and against other

17 U.S. News and World Report, 9 March 1970, p 16.

18 See "Cuban-Americans' ethnic unity delivers open 18th to GOP," Congressional Ouarterly Weekly Report, Volume 47, 2 September 1989, p 2266. An unsuccessful 1986 attempt by a Cuban-American to win election to Congress from New Jersey's 14 th District is discussed in Congressional Quarterly Weekly Report, Volume 44, 5 July 1986, pp 1537-1541. 
"leftist" enemies throughout the hemisphere makes interesting reading. The appendix contains a compilation of this history, whose radical and widespread nature points to the abilities possessed by this portion of the community.

For the vast majority of refugees the process of adjustment to North America was much more mundane. In the aftermath of the Bay of Pigs failure, many exiles abandoned plans for a quick return to the island, and others, as the years passed, reconciled themselves to the certainty of a prolonged or permanent stay in the United States. ${ }^{19}$ The influx to Florida rather quickly strained Dade County resources, and worsened welfare, education, health, employment, and crime problems.

Clearly, the situation in Miami contributed significantly to the creation of the strong effort aimed at placing Cubans throughout the United States, and resettlement operated in full earnestness by mid-1961. Felix Masud-Piloto, although admitting that Kennedy's exact political motivations cannot be ascertained, marshals strong evidence "that the cuban Refugee Program was central to (his) plans to overthrow the

19 Masud-Piloto, p 47. See statement of Roberto Suero, Member, Advisory Council, Cuban Refugee Center, $p$ 176, and William Mitchell, Commissioner of Social Security, p 192, in testimony before subcommittee of Refugees and Escapees of Senate Committee on the Judiciary, Carlos E. Cortes, editor, Cuban Refugee Programs (New York, 1980). Maria de Los Angeles Torres in The Nation, 24 october 1988, p 394, claims that 53\% of Cubans in the United States wished to settle permanently in the United States in 1973, a figure that rose to $95 \%$ by 1979 . 
Cuban revolution. "20 The threat of communism in the hemisphere remained at the core of official American response to the situation in cuba. The effect of the loss on the cuban regime was paradoxical:

on one hand, the departures hurt the revolution because the urgently needed professionals could not be replaced fast enough... on the other hand, the departure of a large part of the political and economic elite made castro's political consolidation easier and faster. ${ }^{21}$

Visa waivers granted by the state Department after the breaking of relations between the two countries in January of 1961 facilitated the arrival of an increasing number of refugees. An American offer (August 1961) to absorb the cost of transporting those who wished to leave expedited departures, and most of these refugees boarded KLM and Pan Am commercial flights linking Havana to Miami.

An American response slowly took definite form. No statutory aid was applied to the cuban situation until 1962 when Congress enacted the Refugee and Migration Act. In this early period all Federal aid, which grew to cover various aspects of the situation, came from the chief executive's discretionary funds. Congressional hearings proliferated throughout the early part of the decade, with a mixture of concrete concerns about overloaded systems and reports on the 
progress of resettlement, all usually placed against a background of the alleged communist threat.

Given Cuba's historical Catholic background, unsurprisingly the vast majority of those who arrived in Miami without a firm local situation awaiting them turned to Catholic agencies for resettlement aid. By May of 1963, however, significant Protestant groups had begun trying to place refugees throughout the rest of the United States. ${ }^{22}$

other relief programs were established early in the decade. Most of the seminal examples occurred in South Florida, including the University of Miami's training of Spanish teachers and a medical refresher course, and efforts by Miami's library system and the Parent Teachers Association. ${ }^{23}$ It is important to note that one of the few start-ups outside of Florida was the optometry program begun by Pacific University in Forest Grove, Oregon.

Cancellation of regular air service after the 1962 October Missile crisis reduced the flow of cuban arrivals

22 "Protestants to aid Catholic refugees," The Christian Century, 29 May 1963, p 702. By 1973 Rafael J. Prohias and Lourdes Casal listed resettlement figures by agency as follows: United States Catholic Conference--63.6\%, IRS-20.9\%, CWS--14.6\%, HIAS--1.0\%. The cuban minority in the U.S.: Preliminary Report on need identification and program evaluation (Boca Raton, 1973), p 108, Table 46.

23 For a fuller listing of Teacher Training Projects of the Cuban Refugee Program see Professional Manpower: a new way to meet the need, U.S. Cuban Refugee Program, Social and Rehabilitation Service, Department of Health, Education, and Welfare. 
to Miami. ${ }^{24}$ This reduction and the relatively orderly nature of the influx prior to a new migration in the fall of 1965 allowed American aid and resettlement programs to function effectively, with the caveat that many of the early cuban migrants faced very difficult times in trying to adjust. Passage of the Refugee and Migration Act in 1962 led to setting up a hierarchy and process. The Department of Health, Education, and Welfare's Office of Welfare Administration controlled the overall program, while education matters were handled by the Department's office of Education. Arrangements with local and state agencies in Florida, followed by similar agreements with state welfare agencies throughout the nation, led to resettlement of cubans in every state in the union. officials attempted to boost resettlement efforts in January of 1964 when aid was cut off to new arrivals who refused placement away from Miami.

24 The Cuban government's decision to close all airports to commercial traffic took effect on 23 October 1962. The reduced number of migrants after this time "have consisted primarily of the refugees who have arrived on the ships and planes which have returned to the United States after delivering medical supplies to Cuba in connection with the prisoner agreement. They have also included relatively small numbers of refugees who have reached this country after escaping illegally from cuba in small boats and refugees who originally went from Cuba to a foreign country... the number of resettlements has declined." statement of Ellen winston on 19 June 1963, study of Population and Immigration Problems, Committee on the Judiciary, Subcommittee Number 1, House of Representatives, Special series Number 14, 1963, p 4 . 
On 28 september 1965 a radio broadcast from Havana carried a speech by Premier Castro in which he announced that Cubans with family in the United states could leave if their relatives asked for them. ${ }^{25}$ President Johnson accepted the offer and challenge in language that continued the anticommunist theme, prompting many Cubans to begin the application process. ${ }^{26}$ In an unhelpful gesture, the Castro government designated the fishing village of Camarioca, located 60 miles from Havana, as the embarkation point. The hazards of a 90-mile mass migration on crowded small craft quickly prompted discouragement by American officials. Nonetheless, some 3,000 voyagers ventured forth, while the probability of failure in the efforts of the two governments to reach an agreement began to seem likely.

Negotiations undertaken by Swiss Ambassador Emil Stadelhofer, who carried responsibility for American interests in Havana, resulted in an Agreement signed and entered into force at Havana on 6 November $1965 .^{27}$ The boat exodus quickly ceased, and from 1 December 1965 until 6 April 1973, 3,049

25 Masud-Piloto, p 57; U.S. News and World Report, 11 October 1965, p 15.

26 Masud-Piloto, pp 60-61.

27 "Movement of Cuban Refugees to the United States." Treaties and other International Acts Series, 6063, 6 November 1965. 
flights carrying 260,561 Cubans conducted "the largest airborne refugee operation in American history." 28

The slogan "Freedom Flights," which reflected the old theme of refugees escaping communist clutches, rapidly gained currency in the United States. As this massive influx had profoundly influenced the establishment of a permanent Latino community in Southern Florida, stresses and strains resulted immediately from trouble between Miami's Afro-American community and the burgeoning number of Cubans. Additional pressures buffeted Dade County's social service institutions, which led to resettling the immigrants elsewhere. Thus, other major cities, including New York, Chicago, and Los Angeles also developed significant Cuban communities, although Portland had already received a large percentage of its total Cuban arrivals.

Thus, in the sixth year of the Cuban Revolution, there was widespread speculation, especially in North American journals and magazines, about Fidel's motives in releasing large numbers of Cubans who displayed obvious happiness upon their arrival in Miami. ${ }^{29}$ Some analysis centered on economic

28 Masud-Piloto, p 68.

29 See "Another Exodus," The Christian Century, 27 October 1965, p 1310; , "New Flight from Castro--New headache for U.S.," U.S. News 25 October 1965, pp 55-56; "Why Castro allows Cubans to flee--the dictator's worries;" U.S. News and World Report, 8 November 1965, pp 49-51; "Free to leave;" Senior Scholastic, 4 November 1965, p 20; "Fidel's pizzeria diplomacy paves the way for an exodus; Swiss Ambassador acts as United States mediator," Life, 5 November 1965, pp 38-39; Gertrude Samuels, "Why Castro exports Cubans," New York Times 
problems, especially food shortages, while others cited Fidel's desire to eliminate dissidents. A wider view placed the cause of the exodus on Castro's hope of lessening dependence on Russia and a complementary desire to open trading relationships with the United States. Finally, there was speculation that castro wished to create problems for the United states, either in the short run, via logistical pressures, or in the long run, by the establishment of a precedent with significance for the rest of Latin America. Certainly Castro's political expertise enabled him to manage the timing and size of the migratory flows between cuba and North America, and the United States government enjoyed few options. The refugees' disinterest in settling elsewhere in Latin America also contributed to the situation.

A new aspect of the Cuban flights emerged in January of 1967 when a change in Cuban policy allowed 900 dual citizens and 1,800 persons with relatives in the United States to leave the island on chartered Pan Am flights to Merida, Mexico, and from there to make their way to the United States. From the media perspective the most spectacular episode involving refugees during the period of the "Freedom Flights," occurred in January of 1969. Early that month about eighty-eight Cubans successfully entered the American military base at Guantanamo, perhaps under fire from Cuban soldiers which may

Magazine, 7 November 1965, pp 30+; "Cuban Exodus resumes," America, 1 January 1966, pp 3-4. 
have killed fifty or sixty of their compatriots. ${ }^{30}$ Later in the year there was the third defection during the preceding three-and-a-half years by a Cuban national flying a Russian MIG.

The cuban cut-off of the airlift program in 1973 drastically decreased the number of direct arrivals, forcing refugees to go first for a time to a third country, usually Spain. This situation endured until the events of early 1980.

As the novelty of the migration wore off, American journalistic coverage of the community, apart from events such as these, turned towards analysis of the progress of the relationship between the new Cuban-Americans and the North American polity. Reports of the early arrivals' relatively well-off status ${ }^{31}$ were complemented by articles that concentrated on their notable economic successes. ${ }^{32}$

30 American news magazines favored different versions of the incident: "Freedom Riders," Time, 17 January 1969, p 31; "Guantanamo Incident," Newsweek, 20 January 1969, pp 44-45; "Drama of a flight from Castro terror;" U.S. News and World Report, 20 January 1969, p 5; "88 got away," National Review, 28 January 1969, p 60. Newsweek cast doubt on the credibility of the story as told by U.S. officials and well-coached refugees.

31 Tom Alexander, "Those Amazing Cuban Emigres, " Fortune, October 1966, pp 144-149.

32 "Cuban refugees write a U.S. success story," Business Week, 11 January 1969, pp 84-86, ties the nature of the exiles as a "propertied elite," "professional," and "managerial" types to corporate success which was spanning out through Latin America, an observation that proved far-seeing in light of the later development of Miami. "Cuba's new refugees get jobs fast," in the 12 March 1969 edition of Business Week, p 69 , places the quick success of the exile community in a larger context, that of the American business boom and the 
Most of the articles written about the community throughout the decade focused on Miami's role at the center of this economic upswing. The literature abounds with admiration for the revitalization of Miami that began with the arrival of the first refugees after the revolution. The creation of "Little Havana," replete with the smells, sights, and sounds of Latin culture provided a perfect journalistic hook, and led, for those interested in the wider implications, to a key explanation for the growing international economic and cultural ties that were transforming Miami. The ambience now available in Miami attracted political/economic refugees from other Latin American countries, and financial leaders from throughout the Americas grew comfortable with the Miami connection.

Conflict with Miami's Afro-American population continued, as newly arrived Cubans displayed an initial willingness to compete for low-paying jobs, while also receiving special aid programs unavailable to other deprived groups. As entrenchment in Southern Florida and economic success followed

Vietnam war. See also "A Cuban Success Story--In the U.S.," U.S. News and World Report, 20 March 1967, pp 104-106. "Flight from Cuba--Castro's loss is U.S. gain," U.S. News and World Report, 31 May 1971, pp 74-77, contains an overall view of the "seldom matched" total success story of the community. "Bicultural Americans with a Hispanic tradition," Wilson Library Bulletin, March 1970, pp 722-723, places the success story in a cultural matrix, using terms such as: "educated refugees," "light-skinned," "the threat of American matriarchy," the "exemplary" racial co-existence demonstrated by the community, and also notes the "refurbishing" of Miami, that became increasingly clear throughout the decade. 
Cuban efforts, white flight and black anger continued to be important issues attached to the Cuban presence. ${ }^{33}$ several other Cuban cultural items, notably santeria, the island's traditional practice of voodoo, and baseball, a much-loved sport by Cubans, continued to receive notice in American journalism.

The most important cuban community outside of Miami was that spanning the border between Union City and West New York, New Jersey. Calvin Trillin's article in the New Yorker was the first important notice given to this community in the national press. Later reports centered on the violence that occurred in the area in the aftermath of the attempt by some Cuban-Americans to effect a rapprochement with Fidel. ${ }^{34}$

official evaluations of the resettlement program began to appear in the 1960s. John Thomas, Director of the Federal Cuban Refugee program, in addition to testifying before Congressional Committees with other government officials, wrote several descriptive articles explaining various aspects

33 The matter is not, however, clear-cut. See John Egerton, "Cubans in Miami: A third dimension in racial and cultural relations," Carlos cortes, editor, The cuban Experience in the United States (New York, 1980). Some of Egerton's respondents state that black anger was not necessarily directed towards cubans, but rather focused on power holders. Neither was this sentiment unanimous.

34 Calvin Trillin, "U.S. Journal: Union City, New Jersey," The New Yorker, 30 June 1975, pp 94-96. 
of the fledgling resettlement program in the early $1960 \mathrm{~s}^{35}$ Katherine Oettinger, chief of the Children's Bureau of the Social Security Administration, in 1962 delineated "Services to Unaccompanied Cuban Refugee Children in the United states," which was supplemented by a 1967 HEW release. ${ }^{36}$ The Comptroller-General's office published surveys of the resettlement program's financial aspects in 1965 and 1972 .

Social science scholars also took seriously the Cuban refugee communities in the 1970s. Historical evaluations were notable by their absence, except for Masud-Piloto's excellent study, but other disciplines were well-represented in the literature. ${ }^{37}$ Not unexpectedly, Cuban emigre scholars began to study their compatriots' condition.

In 1977 three such distinguished students published an article that attempted to present a "descriptive profile of a sample of recently-arrived cuban exiles." 38 Their summary

35 See "Cuban Refugee Program," Welfare in Review, Volume 1, number 3, September 1963, and "Cuban Refugees in the United states." International Miaration Review, Spring 1967, pp 4657 .

36 Katherine Oettinger. "Services to Unaccompanied cuban Refugee Children in the United States," The Social Service Review, December 1962, pp 377-384. Katherine Oettinger and John Thomas. Cuba's Children in Exile: the story of the Unaccompanied Cuban Refugee Children's Program, U.S. Department of Health, Education, and Welfare, Social and Rehabilitation Service, Children's Bureau, 1967.

37

See essay on sources.

38 Alejandro Portes, Juan M. Clark, Robert L. Bach, "The new wave: a statistical profile of recent cuban exiles to the United States," Cuban Studies, January 1977, p 31. 
included a number of points that demonstrated a congruence with the earlier arrivals: the emigres' relatively old age and their whiteness compared to the whole of the Cuban population; the fact that a large percentage encountered economic, transportation or language difficulties; and their tendency to rank job security, increased education and higher status as top priorities.

In other areas the newer arrivals differed from their predecessors: although also predominantly urban in origin they were less so than previous groups; they were better educated than were Cubans generally, but had less schooling than previous refugees; their middle-level backgrounds involved lower status than that of the first wave of cubans; and the downward mobility that greeted them in North America yielded comparatively lower incomes than previous arrivals earned. These later emigres benefitted from the already extant kinship network, thus many expected to remain in the Miami area. The changed political climate meant that, unlike the earlier arrivals, expectations of returning to cuba were virtually non-existent, and a large percentage anticipated obtaining U.S. citizenship. 39

A second study based upon the use of Immigration and Naturalization Service statistics also cast light on the demographic make-up of the pre-Mariel Cuban community. The 
authors examined cuban arrivals from 1960 on in terms of percentage of both total and Hispanic migrations. Outstanding characteristics of cuban arrivals included their relatively older age, the 53-568 female population, the intention of the overwhelming majority to live in Miami, and the primarily operative nature of their job skills, a background that yet remained elevated compared to other Hispanic migrants. ${ }^{40}$

These transformations in the arrivals' profile were accompanied by some changes on the macrocosmic political level, as a move towards rapprochement with the cuban regime began to surface among the exile community during the middle part of the 1970s. Feelers from the cuban government led to the formation of the "Group of Seventy-five," whose membership included a number of prominent exiles.

A dialogue began within the Cuban-American community, and when some of the "Group" leaders agreed to a 1978 meeting with Castro in Cuba violence replaced discussion in some quarters. Nonetheless, more than 100,000 exiles made visits to the island during the latter part of the decade.

While the radical portion of the cuban community continued to react with disdain and violence, the general tenor seemed to be moving towards favoring a compromise. A wider range of approaches was demonstrated within the Cuban-

40 Douglas S. Massey and Kathleen M. Schnabel, "Recent trends in Hispanic migration to the U.S.," International Migration Review, Volume 17, summer 1983, pp 212-244. 
American community as is shown by the active efforts of the Antonio Maceo brigade, whose members went beyond merely visiting family to take an active hand in projects underway on the island. Arieto, the most important exile publication, also adopted a conciliatory tone towards the castro government. ${ }^{41}$ Meanwhile Fidel also allowed 22,168 people to emigrate to the United States under the political prisoners program. ${ }^{42}$

In spite of this reconciliation activity, there were no concrete moves towards an official change in policy by the Johnson or Nixon administrations. Rather anti-communist cold war rhetoric continued to dominate American public policy. Two conciliatory steps taken by President Gerald Ford which involved lifting a ban on trade by foreign subsidiaries of U.S. firms and removing the eleven year old OAS sanctions quickly were offset by the "massive infusion of cuban troops in support of the Soviet-backed guerrilla faction in Angola." 43

No major, substantive changes in Cuban-United states relations followed the election of a Democratic administration, that of Jimmy Carter, by the American

41 See Joan Didion, Miami (New York, 1987), pp 116-122. The author discusses the unsuccessful calls for dialogue promulgated by Arieto, and the "Group of Seventy Five."

42 Masud-Piloto, p 78.

43 Congressional Quarterly Weekly Report, 31 May 1980, p 
electorate in the 1976 presidential election. Meanwhile, later arrivals and children born on the mainland joined the earlier migrants in effecting assimilation of the Cuban emigre community into American life. The thaw which had placed the community in closer relationship to the island's power structure proved temporary, thus increasing incentives favoring the transition to American ways. Demographic differences between older emigres and cubans who made the journey to North America in later decades were slowly being enhanced by the contrasting environments of Cuba and the United states, a situation which did not become clearly manifest until the aftermath of the events leading to the Mariel exodus in the spring of 1980. 
CHAPTER III

\section{CUBAN-AMERICANS :}

MARIEL AND BEYOND

During his administration, President Jimmy carter expressed sympathy for the idea of normalizing relations between the United States and Cuba, and made a number of moves in this direction, culminating with the opening of interest sections in Havana and Washington by the American and Cuban governments respectively. 'Castro's international adventures, which involved offensives in Africa--chiefly Ethiopia and Zaire--and in the western hemisphere--most importantly a "flareup over the disclosure of a soviet combat brigade in Cuba," and charges about cuban sponsorship of revolutionary activities in the Caribbean and Central America--were used by American officials to blunt progress made between the two nations on trade issues and over the release of political prisoners. ${ }^{2}$

1 See Masud-Piloto, pp 71-78 for an overall view, including favorable attitudes expressed by Cuban officials.

2 Congressional Quarterly Weekly Report, 31 May 1980, pp 1502-1503. Carter's moves included granting visas to Cuban citizens, lifting the ban on travel to Cuba by Americans, allowing charter flights between the two countries, stopping spy flights over the island, and easing the trade embargo. 
Failure to resolve bilaterally the issues came to have important implications during the events of the Mariel exodus in the spring of 1980. The enactment into law of the Refugee Act of 1980, with President Carter's signature on 17 March, was an effort by the American government to solve unilaterally the increasingly difficult question of refugee migrations. The problem had grown acute in North America in the latter half of the 1970s due to the wave of vietnamese who left their nation in the aftermath of the long war there. Both economic implications created by the growing number of refugees, and traditional opposition to foreign arrivals, i.e., nativism, played a role in American perceptions. Events in Cuba illustrated the shortcomings of the one-sided approach adopted by the United States.

A dispute between Cuba and the Venezuelan and Peruvian governments over the issue of asylum, a right traditionally granted throughout Latin American history, developed in midJanuary of 1980. Earlier, Peru and Cuba had clashed over supposed Cuban aid to sendero Luminoso, the Maoist revolutionary movement centered in the Department of Ayacucho in Peru. On 1 April a vehicle crashed into the Peruvian embassy in Havana, and a Cuban soldier was shot while the passengers successfully made their way into the embassy grounds. On 4 April cuba withdrew its guards from around the Peruvian embassy in Havana and some 10,800 Cuban citizens 
quickly made their way into the grounds seeking asylum and exit from the island.

Post-mortems expressed a wide divergence of views about the events and motivations surrounding this scene, which played before a growing worldwide audience. Predispositions towards the Castro regime and communism determined the interpretation given the exodus, but the complexity of the situation, and of historical processes in general, allow different interpretations to make telling, and often directly contradictory points. Thus, while both admirers and detractors of the Premier asserted that events demonstrated his political acumen, one observer saw a far-sighted cuban policy, fully prepared for a large exodus, ${ }^{3}$ while another source preferred to interpret the April events as an initial Castro misperception and blunder quickly corrected by a master politician. 4 Castro's continued ability to control the rate of migration remained a constant in Cuban-United states relations.

3 Sergio Díaz Briquets, "Demographics and related determinants of recent Cuban emigration," International Migration Review, Spring 1983, pp 95-119. Masud-Piloto, pp 80-82, supports this aspect of the Diaz analysis. Diaz makes a strong case for the relationship between demographic pressures, i.e., a large population growth, and a rational Cuban policy that included overseas military and civilian involvements, education policy, labor migration to soviet bloc countries, and the Mariel exodus.

4 Juan M. Clark, Jose I. Lasaga, Rose S. Reque, The 1980 Mariel Exodus: an assessment and prospect, Council for interAmerican Security, 1981. 
So too, theories about the nature of the emigrants' motivations, and about conditions on the island, revealed the ideological perspective of their authors. Gaston Fernández, one of the new commentators who emerged after Mariel, sided with those who believed that "the cuban regime is experiencing significant legitimacy problems." Fernández was concerned with tracing the disagreement between the few leftist interpreters of the Mariel exodus and the more numerous rightwing students of Cuban affairs. Fernandez dismissed the leftist critique that depicted a lazy disaffected minority, representative of an anachronistic aberration, by offering data that described the Mariel immigrants as an accurate reflection of the island's population. ${ }^{5}$

This aspect of the Mariel exodus is significant, but considerations of the wider issues existing between Cuba and the United States were absent from Fernandez's matrix. The chief error of his approach was the failure to note the relationship between poorer Latin American nations and their more affluent and powerful North American neighbor. Thus, Latin Americans, and indeed people from throughout the third world, often express and execute their desire to transfer their fortunes to the United States. The mechanisms of entry are determined by specific economic and political situations,

5 Gaston A. Fernández, "The Freedom Flotilla: a legitimacy crisis of Cuban socialism?" Journal of Interamerican Studies and World Affairs, Volume 24 , number 1, February 1982, pp 183-209. 
but the widespread appeal of the "American dream" is hardly unique to cuba. Effecting strict separation of economic from political, social, and cultural motivations is a task best left to the heirs of the medieval theologians, whose arguments as to the number of angels capable of dancing on the head of a pin are germane only to those with the extra time to live in such rarified air.

By 21 April 1980 the events in Cuba received prominent play in North American magazines, and transport of the Peruvian Embassy grounds occupants to San José, Costa Rica, was underway by the month's end. A haven in Costa Rica or Peru, which also agreed to take some of the refugees, was not, however, the goal of the would-be emigres, nor of their families in North America. Thus, the rapid appearance of an armada of small boats in the Cuban village of Mariel, due largely to organizational talents displayed by the cubanAmerican community, set the stage for the arrival of some 125,000 more Cuban immigrants into Southern Florida. 6

The ebb tide of the exodus from cuba grew rapidly to flood tide proportions in Miami, and the Federal Emergency Management Agency was entrusted with initial overall responsibility for managing the influx. This arm of the bureaucracy demonstrated inexperience in dealing with such

For the most complete discussion of the exodus see Alex Larzelere, The 1980 Cuban Boatlift (Fort Lesley J. McNair), 1988 . 
a problem and increasingly turned to the Cuban Refugee Emergency center and other previously-used methods, including resettlement help from the private agencies. Eventually, authority was transferred to the state Department and the Department of Health and Human Services. ${ }^{7}$ The approximately $50 \%$ of new migrants who had already established families willing to help were rapidly processed and resettled. The arrival of large numbers without such resources led the government to open four centers located on older military installations.

President Carter's hesitant approach to dealing with the problem--its complexity, historical antecedents, and the election year factor all came into play--meant that Castro was largely in control of determining the exodus' size and length, while American capabilities were little enhanced. The President also briefly adopted his predecessors' anticommunist/freedom rhetoric, thus further muddling the legal situation, given the recently enacted Refugee Act and the presence of large numbers of other, chiefly Haitian, Latin American arrivals in Southern Florida.

By 4 June official figures placed the total of new immigrants at 103,238 . That same week riots broke out at Fort Chaffee and Eglin Air Force Base, and publicity about these incidents amplified the belief that detained Marielitos were

7 Council for Inter-American Security, p 6. 
largely human refuse. This view found wide currency in official Cuban descriptions, which depicted the emigres as gusanos, or worms, and later information confirmed the fact that Castro transported a number of incarcerated individuals directly from their jail cells to Mariel.

The screening process which occurred at opa Locka in Dade County ferreted out a number of felons, 1,776 of whom were relocated to the Federal penitentiary in Atlanta. A number of these were subsequently freed, but replacements gradually arrived as hardened felons repeated their criminal activities. It was this largely replacement crew that staged the wellpublicized riots in late November 1987.

The emerging Mariel profile more closely reflected the composition of the island's population than did those from preceding decades. Thus, Marielitos were less white, less educated, and more mixed in terms of socio-economic class. The large percentage of single men--57\% overall, higher yet in the four camps--contrasted with the figures for earlier arrivals, which showed more female migrants. The camp's homosexual population tended to segregate themselves, thus creating a visible target for North Americans predisposed to dislike them. America's gay community provided relatively quick and effective resettlement for these internees. ${ }^{8}$

8 Karen Dewitt, "Homosexual Cubans get settlement aid," New York Times, 17 August 1980, p A14. 
The distinction between economic and political motivations came to a head with the Mariel influx. The rightwing interpretation of the immigrants' reasons for coming stressed politics, featuring the desire to escape a totalitarian situation. 9 In contrast, "the carter administration resisted granting refugee status to the cubans by arguing that the new arrivals' motivations for leaving Cuba were more economic than political." on 20 June 1981 the Federal government "announced the creation of a new classification: Cuban-Haitian entrant," designed to allow the arrivals to stay and receive Federal monies, with the promise of a future adjustment to permanent residence status. This process occurred in 1985. The same commentator placed the significance of this move in its breaking the tradition of privileged treatment for Cuban immigrants. ${ }^{10}$

The situation in the camps remained tenuous as the resettlement process slowed to a trickle for the remaining, largely single, male refugees. Once again, private and public service agencies in Southern Florida were stretched beyond the point of competence. In August a series of hijackings by arrivals who now wished to return home prompted rumors tying some of the returnees to Fidel's secret police. By 1 September official figures placed the number of Marielitos at

9 Council for Inter-American Security, $p 9$. 10 Masud-Piloto, pp 86-87. 
120,000 on the way to the 125,262 total released by the government on 13 October 1980. On 21 December 1980 the number of inmates at Fort Chaffee was placed at 6,200, while by 9 March 1981 resettlements had reduced the total to 4,000, who were gradually placed throughout the united states during the rest of the year. In February of 1982 the government announced the closure of the camp located at Fort Chaffee, along with word that the facility's remaining 392 inmates would be placed in separate, special psychological care. ${ }^{11}$

The type of journalism that relies on notable events, such as the Mariel exodus, only sporadically found grist for its mill throughout the rest of the decade. After Ronald Reagan's election to the presidency in 1980, suitable topics for reporters could be found in his pandering to the presumably Republican Cuban community. Other newsworthy occurrences included the political success of Cuban-born Miami Mayor Xavier Suárez, continuing mischief by the bad elements in the Mariel community (especially the prison riots in Atlanta), the 1987 defection of Brigadier General Rafael del Pino Diaz, and the exile-Nicaragua Contra connection. At the level of international relations, several moves made by American and Cuban officials towards achieving an immigration accord foundered in mid-decade. A flap over the American government's broadcast of Radio Marti, which featured overtly

11 "What became of the Cubans?" $1982, p 28$.

Newsweek, February I, 
anti-communist and anti-Fidel content, ended one such near miss. Some political prisoners continued to be released from Cuban jails to rejoin their families abroad, and occasional stories surfaced about less visible Cubans making the perilous 90 mile trip between the island and the mainland on tiny, modest floating devices.

Other types of articles focused on longer-range processes in an effort to capture the essence of the cuban-American community. The Latinization of Miami, a process that can be traced to the revitalization of "Little Havana," became a popular theme. The second subject that stood the test of time for journalistic reporting was the right-wing nature of Cuban-American political views. Although more extreme elements of the community have remained understandably obscure, a stridently anti-communist, anti-Fidel thread remained visible in the political articulations of the former refugees. ${ }^{12}$ The twenty-fifth anniversary of the Bay of Pigs invasion received substantial coverage in national news magazines, as the importance of la causa in Cuban exile politics remained clear.

12 See Lucette Lagnado, "Anti-Castro PAC in Washington;" The Nation, 15 October 1983, pp 332-333; Steven v. Cole, "What the U.S. can do to rescue Cuba next;" American Opinion, December 1983, pp 15+; John Rothchild, "The Cuban connection and the gringo press;" Columbia Journalism Review, September/October 1984, pp 48-51; "Miami muzzle: An antiCastro test?" Newsweek, June 16, 1986, p 28. 
There are also signs, however, of contrary impulses within the younger elements of the cuban-American community. The subsequent battle over the exhibition of work of Cuban artists in Miami illustrated a growing pluralism of perspective that pointed towards the maturation and adjustment of Cubans to North America. Maria de Los Angeles Torres' The Nation article skillfully articulated this alternate current. Her brief overview of the "positive signs of change," traced a chronology that culminated by mentioning increased naturalizations and liberalized voting patterns among cubanAmericans in Chicago, participation in Mel King's Boston campaign, and the Cuban-American committee that formed to aid Jesse Jackson's run for the presidency. ${ }^{13}$

There have been worthy syntheses of the contrary elements that comprise the Cuban-American community. Demographic studies continued to develop during the decade which based their brief macrocosmic sociological descriptions on the accumulated statistical evidence. ${ }^{14}$ This demographic approach

13 Maria de Los Angeles Torres, "Cuban-American politics are now in transition, and there are many positive signs of change." The Nation, 24 October 1988, pp 392+. see also Max Azicri,"The politics of exile: trends and dynamics of political change among Cuban-Americans," comment by Enrique A. Baloyra, and Azicri's reply in cuban studies, volume 11:2/12:1 (July 1981/January 1982), pp 55-78, 216-218.

14 See Cheryl Russell, "The news about Hispanics," American Demographics, March 1983, pp 14-25; Thomas D. Boswell and Manuel Rivero, "Cubans in America," Focus, April 1985, pp 2-9; Hispanic Almanac, The Hispanic Policy Project, Inc., New York, 1984; "Hispanic Americans: an emerging group," Statistical Bulletin, October-December 1988, pp 2-12. 
might be summed up:

In comparison with other major U.S. Hispanic groups, the sociodemographic profile of the cubans is fairly unique: a large proportion of middle-aged and elderly persons, a female majority, low fertility, and relatively high socioeconomic status. The latter has been explained by a combination of factors: 1) the socioeconomic selectivity of postrevolutionary Cuban emigration; 2) high rates of female labor force participation; 3) the presence of a strong ethnic enclave.

The most voluminous body of literature in the field, however, belonged to the sociologists. The work of Portes remained vital in this area. A dispute arose over what he dubbed the cuban economic enclave, a situation where new arrivals were employed by already established elements in the Cuban business community. The notion spawned hot rejoinders from some quarters, ${ }^{16}$ but by setting the agenda for the debate, and from the support it received elsewhere, the idea's importance has been established. ${ }^{17}$

Another acute observer of the Cuban community, Lisandro Pérez, accepted the enclave notion as partial explanation for the Cuban success story. Pérez saw the key component as the arriving Cubans' family structure, and postulated this "mid-

15 Lisandro Pérez, "Cubans in the United States," Annals, AAPSS, 487, September 1986, p 126.

16 See Jimy M. Sanders and Victor Nee, "Limits of solidarity in the enclave economy," American Sociological Review, December 1987, pp 745-767.

17 See Kenneth C. Wilson and w. Allen Martin, "Ethnic enclaves: a comparison of the cuban and black economies in Miami," The American Journal of Sociology, July 1982, pp 135160 . 
level explanation" as a bridge between theories of individual and community success.

It is a success story based not as is popularly assumed on the meteoric upward mobility of some individuals whose rags to riches stories inevitably catch public attention. Instead it is the somewhat less spectacular story of an immigrant group with a family unit that is organized around realizing aspirations of economic achievement. ${ }^{18}$

George Borjas preferred to link Cuban success to the heavy investment made by each wave of immigrants in schooling. ${ }^{19}$ Implicit in his view was the pressure exerted by the cuban family favoring school attendance.

Government reorganization of Federal refugee programs, largely as a result of the Fascell-stone Amendment to the Refugee Education Assistance Act of 1980, also led to an increase in official publications about the refugee situation. Thus, Congressional Committees and various Executive Departments produced growing amounts of documentation as the decade progressed. In this respect, Cuban migration and the Cuban role in the resettlement process is most notable for its decreasing presence in refugee literature. Rather, Southeast Asian, and then Eastern European and Soviet arrivals were

18 Lisandro Pérez, "Immigrant economic adjustment and family organization: the Cuban success story reexamined," International Migration Review, Spring, 1986, p 18.

19 George J. Borjas, "The earnings of male Hispanic immigrants in the U.S." Industrial and Labor Relations Review, April 1982, pp 343-353. 
statistically more significant than cubans after the Mariel boatlift.

The failure of the Cuban and United States governments to make progress towards normalization of relations carried unfortunate possibilities for the future. The fouled relationship did little to calm the sharp political tensions that existed in the hemisphere. Meanwhile, the increasingly complex worldwide refugee situation received no help from the lack of communication between castro and the successive Republican administrations. The gamesmanship and "Byzantine bureaucratic and intergovernmental politics, "20 that typified Cuban-American relations after 1959 found its most unfortunate reflection in the impact on the lives of individuals captive to the wider processes. The road to normalization has not been an entirely smooth one for the Cuban immigrants to North America.

oregon, understandably, has been something of a backwater in this process, but due largely to the work of an activeminded Charities Division in the Catholic Archdiocese of Oregon, a Cuban community took shape as refugees were resettled in the state in the early 1960s. Their story bore directly on the larger processes so far discussed, and contained its own interesting dimensions. The remainder of this study is devoted to tracing the history of the Cuban

20 Mario A. Rivera, "Refugee Chess: Policy by Default," Caribbean Review, Fall 1984, p 5. 
presence in the state, including an evaluation of reactions within the metropolitan area, and a description of the former refugees' current status. 
CHAPTER IV

\title{
OREGON AND CUBA: \\ BACKGROUND AND EARLY ARRIVALS
}

\begin{abstract}
We also have to bring out the fact that, well, no matter where you are, if you are in the state of oregon, you are but hours away from Miami.
\end{abstract}

Despite the advent of jet transport, the distance, both literal and cultural, between oregon and Southern Florida remained large in the early 1960s. What was true for nativeborn North Americans proved much more so for Cuban refugees who faced the prospect of resettlement away from Miami to someplace never even glimpsed before.

John Quincy Adams' vision that sought to extend United States boundaries from the Atlantic shore south into the Caribbean and west to the Pacific may well have comprised the first conscious link between oregon and Cuba. The U.S.S. oregon's round-the-horn Spanish American war journey originated in San Francisco, and the oregon regiment that participated in that conflict saw action in the Philippines.

1 Albert K. Trout, functioning director of the Miami office of the IRR, quoted in Carlos Cortes, editor, Cuban Refugee Programs, p 254, in testimony from 13 December 1961 before the Senate subcommittee on refugees and escapees of the Committee on the Judiciary. 
Further, concrete examples of Cuban presence in the state are rare indeed before the 1960 s resettlement.

Records at the state Archives contain correspondence between Cuban libraries, the International office of University Information, and private cuban citizens with the oregon State Library beginning 1 March $1921 .^{2}$ All of the exchanges involved requests for information or materials, including state Library publications; oregon history; initiative, referendum and recall regulations; oregon state College bi-laws and rules; and general book and cultural information donations. The requests' intellectual focus probably accurately reflected the nature of the connection which existed during this period.

Federal Census records barely supplement the paucity of information regarding Cuban presence in oregon prior to 1960. The only trace existed in the category titled Foreign Born Whites, Other America (excluding Mexico and Canada). The 1950 Census listed 440 such people as living in the state. The 1960 Census totaled 1,392 in this category, of whom 152--or 10.9\%--were Cubans. (See Table I) Given that migration from the island during the 1950s was not extraordinarily out of proportion with that from the rest of "Other America", the number 48 that results from the appropriate math may not far misstate the number of Cubans living in oregon in 1950.

2 See files for 1 March 1921; 20 June 1929; 12 and 20 May 1931; 26 and 28 March 1933; 28 August 1933; 23 November 1936; 23 May 1941; 26 May, and 4 and 21 August 1942. 


\section{TABLE I}

FOREIGN-BORN WHITES, OTHER AMERICAN, OREGON TOTALS

$\begin{array}{cccc}\text { Year } & \text { Number } & \text { Year } & \text { Number } \\ 1860 & 19 & 1910 & \\ 1870 & 60 & 1920 & 113 \\ 1880 & 80 & 1930 & 180 \\ 1890 & 98 & 1940 & 199 \\ 1900 & 73 & 1950 & 195 \\ & & 1960 & 440 \\ & & & 1,392\end{array}$

Drawn from Census Reports

It is, thus, somewhat surprising to learn that on 4 June 1953, the Cuban government appointed an honorary consul for the Portland area, Boris Camacho Vega. ${ }^{3}$ The economic ambitions of the Batista government suggest an explanation for this move. That government's second and final accredited consul, Francisco Maribona, arrived in Portland in February 1955. His family followed in August, and was, apparently, the only cuban family living in the city at the time.

Language and other cultural differences made the first three months very difficult for the Maribona children who were placed in private schools, including st. Mary's Academy in downtown Portland. As difficulties increased on the island during 1958, Maribona returned to reconnoiter the situation. He discovered the new regime's intentions towards Batista's

3 Camacho Vega's time in Oregon ended under a legal cloud featuring charges of involvement with minors. He eventually rejoined the Hispanic community in Southern Florida, and resurfaced as bearded Father Chris, leader of his own church, on the Spanish cable network system. 
diplomatic corps, and escaped from the island on a ferry during the first months of 1959. No replacement was ever named to take over the Henry Building consulate and operations ceased early that same year.

As in the rest of North America, Cuba remained distant from Oregonians' awareness until Castro's assumption of power became apparent. In late June 1958 the local newspapers carried page one headlines announcing the kidnapping of a group of American mining engineers by Raúl Castro. ${ }^{4}$ Included in the group was an oregonian, Henry Salmonson, whose presence in the middle of the story brought the situation to the attention of the state. Interviews with Salmonson's family and the progress of the negotiations leading to the eventual release of the hostages, including that of Salmonson on 2 July, kept the proceedings before the eyes of Oregonians for a few days. The oregonian article announcing the release of the first group of engineers contained parts of a conversation with Salmonson conducted at Guantanamo:

'They told us that bombs made in America were being used against them by the cuban government. They showed us what they said were bomb fragments and also pointed out some huts that had been destroyed by fire.' Otherwise he said the rebels took them swimming and on happy tours of the wilderness. He reported food and beds were good.

Such a favorable view of the struggle seems isolated, more

${ }^{4}$ Oregon Journal, 27 June 1958, p 1, 28 June 1958, p 2; The oregonian, 28 June 1958, p 1.

5 The oregonian, 3 July 1958, p 1. 
typical was oregon Journal coverage featuring the information that salmonson was "back on the job."6 The local newspapers' lack of coverage of the revolution's events illustrated the distance between oregon and the island.

The Oregon Centennial Commission's correspondence included the best available documentation of the relationship. The earliest item was a pamphlet from the Banco de Fomento Agricola e Industrial de Cuba announcing Five Years of Achievement, 1951-1956, which arrived during 1958, when Centennial organizers feverishly sought international participation in the celebration. These solicitations met polite rejections by Cuban authorities. The Commission, with the help of Consul Maribona, then appointed forty-one honorary ambassadors on the island. ${ }^{7}$

Another letter mentioned a "breach of protocol with our little man from Cuba--Mr. Maribona--", while discussing cultural and personal difficulties. ${ }^{8}$ During this same period Maribona became involved in an incident at a vancouver physician's office when a partially concealed revolver led to brief confinement at the vancouver police station. A year later, after the closing of the consulate, local newspapers

6 Oregon Journal, 3 July 1958, p 2.

7 See material 60-31, Item 20, in the oregon state Archives between 20 February 1958 and 19 August 1958.

${ }^{8}$ Note from Marge Alexander dated 26 May 1958. 
announced the event. 9 Doug Baker noted that "history has not dealt kindly with Maribona, once a bright spark in Portland's consular corps," as the "former champion of Batista" now found himself broke, exiled in Los Angeles and divorced. ${ }^{10}$ By the late 1980 s Maribona was living in Lacey, Washington, and had reestablished amicable communication with some of his children, three of whom, along with señora Maribona and third generation offspring, remained the oldest part of oregon's Cuban-American community.

Rejections from the Cubans, and Maribona's failure to advance their cause, induced the centennial commission to seek contact with Dr. Pando, the Commercial Counselor at the Cuban Embassy in Washington, D.C. Harold B. Say was entrusted with the job and sent a record of his interview back to oregon:

Cubans have only the most vague idea of our west or its potentials. In their mind even New York or New orleans is distant. oregon is as far away as Mars... (Dr. Pando) is a very serious, solid person, aware of American aggressiveness, etc., and who would like to instill some of it in his people."

There was no more correspondence concerning Cuban participation in the Centennial until after castro's assumption of power. In February Maribona expressed a hopeful tone inasmuch as "the Revolutionary Government is very

9 Doug Baker, Oregon Journal, 13 August 1959, p 7B; The Oregonian, 14 August 1959, p 18.

Oregon Journal, 13 August 1959, p 7B.

Letter dated 11 July 1958. 
interested in participating in this important event." 12 Reality proved different. A final effort was made by Marge Alexander, hired to coordinate the venture:

Is Maribona still consul? We have been informed by reliable sources that he no longer is in that capacity... I might add the state of oregon is presently engaged in a 'beard growing contest.' We are sure they would have much in common with the cubans. ${ }^{13}$

The last communication from Cuba, written beneath a title reading Año de la Liberación, made it clear that the cuban authorities anticipated no participation in the centennial's events. $^{14}$

Congressman Charles 0 . Porter created Oregon's best-known connection to the island in the early years of Castro's regime. Porter's advocacy of returning Guantanamo to the Cubans drew scorn from some quarters, and strong, although mixed response in the letters he received after his 1960 appearance on Face the Nation. Porter believed that his failure to repudiate castro, and a visit with the cuban Premier, hurt him politically both in Washington, D.C., and at home. He cited the veto of his proposed Latin American Ambassadorship in the Kennedy administration by senior Southern Senators, and incidents that occurred in Eugene with conservative opponents of the new Cuban government as evidence

12 Letter dated 7 February 1959.

13 Letter dated 21 March 1959.

14 Letter dated 24 April 1959. 
of the period's sentiment. Support for his position from within the University community was more than counterbalanced by negative responses, such as newspaper advertisements linking his positions on Cuba and other issues to those of Soviet leader Nikita Krushchev. ${ }^{15}$

As refugees began piling up in Miami in late 1960, a secretary with Catholic Relief services, instead of including only large areas, mistakenly sent invitations to a conference on the problem to all 125 Archdioceses in the United states. The lure of airfare and accommodations at the DuPont Plaza Hotel in Miami attracted large numbers of representatives, including Father Morton Park from Portland. When the issue of resettlement was raised, Park went to a nearby telephone and called Margaret Godfrey of the Archdiocese's staff, who had experience in previous refugee efforts, most notably that involving Dutch Indonesians. ${ }^{16}$ The two determined that oregon could immediately handle five refugee families, so Park reentered the conference, where the discussion was yielding no concrete results, and offered oregon's participation.

15 Interview with Charles 0. Porter.

${ }^{16}$ According to the Administrative Manual of the Catholic Welfare Bureau, Inc., there were three refugee programs administered by the Portland Archdiocese prior to the arrival of the Cubans: 1954-1960, "Immigration consisted primarily of people of Germanic ethnic origin, who had been in refugee or displaced person camps in Austria and Germany since the end of World War II;" 1956-1959, "Hungarian Immigration Program (250 individuals);" 1960-1962, "Dutch Indonesian Refugees (49 families)." 
The Church recalled Hugh Mcclune from retirement to head the resettlement program. Mcclune previously coordinated the 1956 Hungarian refugee effort, and played a continuous, direct role in Oregon's resettlement program throughout the 1960s. According to Park, he responded to Mcclune's appeals to place Cubans that other areas were not especially anxious to receive, due to factors such as large family size or possession of skills not easily transferable to North America. Such a welcome, often tendered directly during telephone conversations, induced refugees rapidly tiring of cramped and restricted conditions to fly to a distant corner of the United states. ${ }^{17}$

In February of 1961 the Archdiocese formed a local advisory group to coordinate the anticipated resettlements, while Park and Godfrey received able assistance in day-to-day administrative work from Cecilia Barecevich. Area newspapers announced the placement of the first Cuban in Portland, Elena Rodriguez, in March. ${ }^{18}$ Ms. Rodríguez actually arrived with temporary status, her anticipated duties lying primarily in the Unaccompanied Children's Program, but remained an oregonian and active in Catholic Family Services some twentyeight years after her initial appearance at Union station. The other responsible parties expressed respect for her

17 Interview with Father Morton Park.

18 Oregon Journal, I March 1961, p 1; The oregonian, 2 March 1961, p 6; Catholic Sentinel, 9 March 1961, pp 1, 24. 
abilities, and she proved instrumental in Portland's resettlement program, which grew to include several members of her own immediate family.

Later in March the first refugee family made its way to Portland, followed by the second and third in August and October of $1961 .^{19}$ The pace gradually increased to a rate of one family per week, such regularity automatically placing most of refugee life outside of journalistic interest. A pattern of early refugees helping prepare for and then orienting subsequent arrivals owed much to the efforts of the Agustin Enriquez family, and became fundamental to the lightly-financed Portland effort.

Settlement of a new family gave way immediately to preparations for the next arrivals. Connections with the U.S. National Bank Trust Division and local realtors allowed the Archdiocese staff to stay abreast of housing opportunities. A new phone call from Mcclune would trigger procurement of housing, stand-by travel arrangements with Northwest or Delta airlines, and purchase of necessary household goods, usually from Meier and Frank, where a charge account was opened.

While not accurately revealing individual or total resettlements in oregon, Table II, which details emigres' intentions upon arrival in Miami, demonstrates the state's increased popularity among cuban refugees.

19 The oregonian, 19 March 1961, p 33; Catholic Sentinel, 23 March 1961, p 8; 3 August 1961, p 3; 26 October 1961, p 10. 
TABLE II

CUBAN ADMISSIONS BY PLACE OF INTENDED RESIDENCE OREGON (LEFT) AND PORTLAND (RIGHT)

Year

$\begin{array}{rrrlrr}1958 & 2 & 2 & 1974 & 5 & 4 \\ 1959 & 1 & 1 & 1975 & 26 & 23 \\ 1960 & 1 & 0 & 1976 & 40 & 40 \\ 1961 & 4 & 4 & 1976 \mathrm{TQ} & 12 & 10 \\ 1962 & 5 & 5 & 1977 & 59 & 38 \\ 1963 & 2 & 1 & 1978 & 21 & 18 \\ 1964 & 8 & 8 & 1979 & 2 & 2 \\ 1965 & 32 & 21 & 1980 & 0 & 0 \\ 1966 & 24 & 19 & 1981 & 0 & 0 \\ 1967 & 77 & 60 & 1982 & 21 & 16 \\ 1968 & 92 & 65 & 1983 & 7 & \text { NA } \\ 1969 & 22 & 17 & 1984 & 3 & 1 \\ 1970 & 17 & 15 & 1985 & 1 & \text { NA } \\ 1971 & 61 & 55 & 1986 & 47 & 13 \\ 1972 & 27 & 23 & 1987 & 14 & \end{array}$

Source: Statistical Yearbook of the Immigration and Naturalization Service.

TQ notation stemmed from fiscal year classification change instituted by the Federal Government.

Like other Cuban attorneys trained under the principles of Roman law, Dr. Rolando Estrugo, the first arrival in oregon under a special National Catholic Welfare Council revolving loan fund, was unable to resume practice of his profession in the United states. Estrugo's obvious talents and fluent English made him an invaluable asset to the resettlement effort, however, and Park hired him to handle logistical problems. ${ }^{20}$ By all accounts the choice was a good one, and

20 Preceding section drawn primarily from interviews with Father Park and Margaret Godfrey. 
Estrugo continued his work in other capacities, including an appointment as a lecturer teaching two sections of Spanish at Portland State in 1963-1964..$^{21}$

on 7 March 1962 the National Catholic Welfare Council placed a conference call to fifty-three cities to introduce minors involved in the Unaccompanied Children's Program to the press. Father Park appeared with thirty-seven children who were living in Portland.22 American hopes for widespread underground opposition to Castro spawned strong support for the program, which went into full operation in 1961. Attempts to protect the identity of intelligence contacts led to a variety of methods aimed at concealing which of the refugee children were leaving under CIA sponsorship. Arriving children first went to an unused juvenile detention center, under juvenile court authority, and were then placed in one of six Florida camps en route (theoretically) to a foster home.

Monsignor Walsh spearheaded the children's resettlement effort, which rapidly outstripped the Miami area's capacity. Park, Godfrey, Barecevich, and Rodriguez involved the oregon Archdiocese in this aspect of the refugee program at the same time that the flow of families to the state became regularized. Walsh, operating under court authority,

21 Conversation with Dr. Rod Diman.

22 The Oregonian, 8 March 1962 , p 1. 
subcontracted with oregon resettlement officials, and placement of minors in four group homes became a closely monitored aspect of the cuban presence in the state. ${ }^{23}$

Questions revolving around the retention of acceptable houseparents and living space provided a constant, though minor irritation. More serious were issues which arose over the homes for girls and black males. The girls were originally placed in a basement area at the Providence child care center, near an animal experimentation project. A reshuffling of facilities solved this unacceptable situation, but further problems arose, culminating in complaints lodged by neighbors about noise from a group sing, and location of an alternative space became mandatory. Rina Alvarez's arrival to join her children furnished a nice solution, as her abilities and attitudes provided an ideal houseparent for a newly rented facility.

Little communication existed between the Adult and Children Sections of the Catholic Relief Services in Miami, thus Father Park established his own linkages with the

23 Occasional use was made of other facilities, for example, three brothers, deemed too young for spots in one of the regular homes, lived for a time in st. Mary's of the Valley. Close regulation of the program is apparent from contents of the Administrative Manual of the Catholic Welfare Bureau, Inc. The vast majority of its pages are devoted to the unaccompanied children: status and eligibility are carefully defined, and potential problems and possibilities are dealt with in great detail. The tenuous condition of these minors' situation must be assumed to have weighed heavily behind the decision to so thoroughly cover legal and practical issues. 
Unaccompanied Children's Program on his periodic visits to the city. It became apparent that black children were not being resettled outside of holding camps in Southern Florida, and oregon again offered its modest program as partial relief.

Racism is a sensitive matter anywhere, and while most Cubans will strongly assure American observers that no fundamental prejudice existed on the island (in explicit or implicit contrast to the situation in their new homeland), the careful and nearly complete separation of social facilities that dominated pre-revolutionary life looks very similar to the situation elsewhere in the world. The pride in their light complexion demonstrated by some cubans in oregon further reinforced this judgment, as did segregation of darker unaccompanied minors, and the later rejection of the Marielitos. This is not to obscure the peculiar forms of racial discrimination that exist in the United states, but it was not only North American sensibilities that led to the separation of the black Cuban boys in Portland. Father Park later called the segregated group home a "bad idea," but it was understandable in the context of the early 1960s.

The white Cuban couple originally resettled in Portland to run this home remained on the job only a short time, and was replaced by a new set of houseparents, the Matos, whose escape into the Venezuelan Embassy disguised as tamale peddlers captured the tone of intrigue that exists throughout 
the escape literature. ${ }^{24}$ Unpleasant noises made by neighbors had led to the demise of the first group home, but a new location at Northeast 7 th and Knott proved workable.

According to Park, the group homes became unofficial centers for Cuban and other Hispanic youth in Portland. This was especially so in the home run by "Tony," who had been a high school coach in Cuba. One of the best anecdotes concerning the homes revolved around the relationship that developed between the boys at the knott street duplex and rising Latino minor league baseball players who passed through Portland to play the Beavers. According to Armando Laguardia, Portland State University's Director of Affirmative Action, Bevo Hector Martinez facilitated the arrival of various Latin players at the Knott street home. Among others, Tony oliva and Rod Carew, later two of baseball's premier stars, ate several meals there following brief recreational outings with the cuban boys in the neighborhood park. ${ }^{25}$

Newspaper articles made it apparent that, as elsewhere, even after the failure at the Bay of Pigs many of Portland's refugees maintained hopes of returning to the island. Published interviews yielded excoriation of Fidel and communism, while assimilation of the growing number of

24 Interview with Father Park. The oregonian, 31 January 1963, p 13. 
arrivals, whose demographic make-up seems to have corresponded to the larger patterns, continued at a steady pace. ${ }^{26}$ As parents of Unaccompanied Children made their way out of Cuba they were rapidly reunited with their families, leading to the closing of the group homes.

Catholic Relief aid did not end with the thirty days rent provided new arrivals. Schools, medical attention and employment were all made accessible. Strife between refugees with different political views, such as occurred in some areas, never became a problem in Portland, due largely to oregon refugees' relative sparsity and the distance from the wider cuban community. The few potential problems were rendered irrelevant by enforcement of careful separation, such as the placement of a reputed member of Batista's feared tigres far from the rest of the cubans.

There was little contact with the few upper-class cuban adults who lived in Portland prior to the revolution. These people "had no use for brought-in Cubans," and kept a distance. ${ }^{27}$ contact between the children of this small upper

26 The only concrete support for this analysis appeared in a 16 July 1963 letter written by Andrew Juras to Governor Hatfield: "Significant factors noted are that the earlier refugees included people who had more education and were more highly skilled. During the early part of 1963, those who came to oregon had less education and very limited skills. The last group arriving the last week of May and during the month of June included many with greater education and professional skills."

27 Interview with Father Park. 
class community and new refugee children was a different matter. Schools such as st. Mary's provided the medium where the adjustments already experienced by the Maribonas proved a valuable asset, and friendships blossomed which continued into the subsequent decades.

Virtues possessed by the early migrants--"delightful, ingratiating people," "dynamic, nice, leaders"--eased the transition. 28 Both Park and Godfrey cited the case of Rafael Cancio, Sr., licensed as a pharmacist at home, but unwilling to accept the public assistance that was a necessary part of the schooling required to renew his skills for use in the United states. Cancio quickly adapted to his new situation, refused all extraneous aid, and demonstrated a high degree of self-starting motivation and Cuban-style independence, such as long walks across town in lieu of proffered rides. While working as a janitor at I Magnin's, Cancio met Portland businessman Paul Nagel who was seeking spanish language instruction, and the two eventually formed a partnership in a successful janitorial service. 29

Such a reaction was overwhelmingly the norm for arrivals in the early period, and combined with a spirit of rendering aid, rather than making invidious comparisons, to smooth the transition for those who followed. Official and institutional

28 Interviews with Margaret Godfrey and Father Park.

29 Interviews with Father Park, Margaret Godfrey, Paul Nagel, and Rafael Cancio, Jr. 
responses also proved essential to the transition of the Cuban-American community. Chapter Five deals with the nature and scope of the reply offered by citizens and agencies already residing in the state of oregon at the time of the Cuban influx. 


\section{CHAPTER V \\ CUBAN-AMERICANS IN OREGON: \\ THE STATE RESPONDS}

While Oregon's Cuban-Americans labored to make the transition to their new home, local papers focused on a few newsworthy aspects of the story. Tales of harrowing escapes and heartwarming reunions dominated the coverage, but were supplemented by descriptions of adaptation to American customs, such as Thanksgiving and Christmas festivities. Negative comments about Castro and communism found frequent expression in published interviews. The Catholic Sentinel carried numerous reports about deprivations suffered by the Cuban Church, although a gradual softening emerged during the second half of the 1960s.'

The missile crisis in october 1962 brought cuba back into the forefront of American consciousness. Sig Unander, the Republican nominee against Senator Wayne Morse, tried to make use of the situation in the final days of the campaign. After

1 For an interesting history of the deteriorating relationship between the government and the church on the island see Michael J. McNally, Catholicism in South Florida, 1868-1968 (Gainesville, 1982). Chapters six and seven discuss the background and impact of the cuban migration in south Florida. For a five stage description leading up to a general expulsion of Church personnel see pp 130-132. 
stressing the communist threat and trying to tie his own position to that of President Kennedy, Unander capped his attack on Morse:

No weasel words, no flannel-mouthed statements he has offered in the past week can obscure the record of Senator Morse in respect to the Cuba threat... add your convictions to those who will stand up for freedom...n not support the voice of appeasement and double talk. ${ }^{2}$

Morse replied the next day with a speech characterized by oregon Journal reporter Tom Stimmel as a "spellbinder." The Senator's design, aimed at denigrating his opponent's credentials in comparison with his own, was accomplished as he "shared background gained as chairman of the sub-committee on Latin American Affairs and shared knowledge gained as a professor of international law." ${ }^{3}$ The oregon electorate agreed with the favorable response of Morse's student audience and gave the incumbent an impressive victory. The few public utterances from Oregon's Cuban-Americans during the crisis and its aftermath harmonized with Unander's tone and expressed hope that Fidel would soon be deposed.

The missile crisis also spawned another, equally obscure sentiment from a different group of oregonians. The oregon Journal noted:

A populace generally inspired to national unity gave little apparent support to a handful of 'peace

2 Oregon Journal, 29 October 1962, p 10.

3 oregon Journal, 30 October 1962, p 2 . 
marchers' who opened a three-day Portland demonstration at the Pioneer Post office Thursday."

The eleven marchers elicited more antagonism than support, but were among the small group of dedicated leftist activists who make up a piece of the state's political fabric.

Two events in 1963 further revealed contrasting elements of Oregon's relationship to the Revolution. In February Robert Morton Geddes, whose wife lived in Eugene, was freed from a Cuban jail and made his way to Mexico. Geddes had been jailed the night of the Bay of Pigs invasion in Havana as part of an island-wide crackdown by the government against potential opponents. Although he received a thirty year sentence for counter-revolutionary activity prior to his release, Geddes maintained that his position with Pepsi cola was entirely aboveboard. ${ }^{5}$ Late in the year ex-congressman Porter again drew fire from Cuban-Americans for expressions of sympathy with the Cuban regime. ${ }^{6}$

The Portland Reporter and The oregonian carried stories in August 1964 about Aloha student Roy Wilson's return from the island. Wilson's June trip with eighty-three other students occurred despite a state Department ban, and the tour was designed to place the government's authoritarian elements in the best possible light. Wilson distanced himself from

4 Oregon Journal, 26 October 1962, p 6 .

5 The Oregonian, 19 February 1963, p 4.

6 oregon Journal, 7 December 1963, p 2. 
communists, especially those of a Leninist ilk, while also noting that he had "matured beyond his affiliation with the Democratic party," whose leader, President Lyndon Johnson, he depicted as (Republican nominee Senator Barry) "Goldwater with kid gloves on." Wilson allied himself with Senator Morse's criticism of United States policy in Vietnam, and also opposed American non-recognition and blockade of Cuba. ${ }^{7}$ A troubling aspect of wilson's opposition to mainstream views involved FBI harassment and surveillance suffered after the cuban trip. ${ }^{8}$

In more recent years leftist political activity in oregon focused on situations elsewhere in Latin America. Nonetheless, sympathy for Fidel's revolutionary experiment remained a given in this group. Oregon's Cuban-Americans responded to another manifestation of this outlook in 1970 when the oregon Journal reported the "dim view" they took in response to "the migration via canada of American students to help Fidel with his sugar cane harvesting." "9

The tension reemerged publicly early in the 1980s. An oregon journalist, Karen wald, eventually cemented her relationship with post-revolutionary cuba by moving there with her school-age children. Wald continued to return to the

7 The Oregonian, 17 August 1964, p 25.

8 Portland Reporter, 19 August 1964, p 6.

9 oregon Journal, 16 February 1970, p 2. 
Northwest as a strong advocate of the Cuban experiment. ${ }^{10} \mathrm{~A}$ public meeting held in Portland on $30 \mathrm{July} 1989$ featured speeches by Wald and her daughter before a small, rapt audience. Wald's experience and lively intellect lent her overwhelmingly positive evaluation an authority otherwise difficult to encounter.

oregon's cuban emigres share none of her sentiment. A far more accurate evaluation would assert the dialogue held that evening might rouse many Cuban-Americans to a dangerous pitch involving the possibility of physical conflict. Further, the stories told by former refugees about the situation since Fidel's takeover conflicted directly with the Walds' evidence. This observer was present that evening, and while sympathetic towards some of the general critique lying beneath the evening's analysis, was amazed and appalled by the revival atmosphere and smug certainty evinced by many in attendance. None of my respondents at that meeting had met more than a single wayward Cuban-American, and most were quick to express disgust for the views presumably held by these newer oregonians. ${ }^{11}$ The Cuban presence in the room was limited to that brought by Wald and the abstract analyses contained in the numerous tracts available at back tables.

${ }^{10}$ The Oregonian, 24 August 1983, p B2.

11 Portland Saturday Market's lively, elderly Cuban musician was mentioned by several persons during the course of the evening. 
While most oregonians also turned their attention to other matters during the 1960s, certain arrivals, and lingering anti-Fidel, anti-communist sentiment continued to merit special notice. Protestant sponsorship of refugees in oregon began in early February 1963 with announcement of the airplane transport of seventy persons "under auspices of the Greater Portland Council of Churches and the oregon Council of Churches."12 In May 1963 the rare appearance of Jewish refugees received brief attention, while in July of that same year both major dailies covered the cross-country automobile journey of the Isidro and Calderon families. These migrants were resettled with aid from Portland's First christian and First Presbyterian Churches. ${ }^{13}$

Resources appeared from numerous quarters throughout the decade. Catholic Archdiocese officials, after helping to meet basic needs, offered both spiritual instruction--such as the special masses held in 1962 and 1963--and coordinated further relief measures with local and state agencies. Spanish masses were offered regularly for a while beginning in 1972, when

12 oregon Journal, 2 February 1963, p 9. The flight was cancelled and then rescheduled for september, 1963, oregon Journal, 11 September 1963, section 2, page 3 .

13 The oregonian, 15 May 1963, p 15. John Egerton, in Carlos Cortes, editor, The Cuban Experience in the United States, p 2, says that 10,000 of Cuba's 12,000 Jews fled the island in the aftermath of Fidel's takeover, there is no other evidence of arrivals in oregon. The automobile trip is covered in the oregon Journal, 3 July 1963, p 2; The oregonian, 4 July 1963, section 3, p 7. 
Spanish-born Father Martin responded to the favorable reaction generated after a special mass donated by Herminia Arias. Notice of Church efforts made by Governor Mark Hatfield in 1961, and by Portland's local B'nai B'rith Lodge in 1963 testified to Catholic effectiveness. ${ }^{14}$

The language barrier created problems everywhere, a reality reflected in Oregon's response. English programs already extant at Lincoln and Cleveland High Schools added Cubans to their classrooms. Red Cross and Portland state University Peace Corps volunteers also initiated language instruction for the new arrivals. The Red cross effort included meetings for cuban women designed to go beyond language training, by focusing on cultural adaptation.

Apart from the Church, Pacific University in Forest Grove generated the widest effort to help meet the refugees' needs. Two programs created by the University, one in the college of Optometry and the other in the School of Education, functioned smoothly as they successfully retrained emigres to work in the United states. University involvement dated from Dean william Baldwin's arrival from Indiana to head the college of Optometry. Low-level financial shenanigans neutralized the small refugee effort at that Midwestern University, but Baldwin retained the notion of providing assistance to

14 Catholic Sentinel, 16 March 1961, p 5; 26 september $1963, p 8$. 
Cubans. ${ }^{15}$ Pacific's environment proved ideal, as both University President Miller Ritchie and Dean of Admissions Gerald Reese had lived in Southern Florida.

Cuban professionals faced varying degrees of difficulty trying to re-enter their chosen fields in the United States. Adjustment proved virtually impossible for lawyers trained under principles of the Napoleonic Code, but dedicated effort allowed many other refugees to resume careers. Pacific's program, which began in the fall of 1963, was the first aimed at optometrists, and included a special emphasis on English language skills. Although figures for the number of admittances varied, Baldwin stated that ultimately twelve men and women participated in the two and a half year course. ${ }^{16}$

Federal aid, in the form of plane fare, student loans, and additional monies underwrote the program. Forest Grove community organizations, such as the Chamber of Commerce and the Methodist Church, also enlisted to ease the transition for these and subsequent cuban students.

Jerry Reese and Lowell Ellis, a language professor at the University, flew to Florida before the beginning of the 1964 summer session to select candidates for enrollment in a

15

Conversation with Dean William Baldwin.

16 The Oregonian, 14 August 1963, p 15, says 10; Oregon Journal, 12 September 1963, p 3, says 11; The Oregon optometrist, July-August 1963, p 14, says both 10 and 11; Professional Manpower: a new way to meet the need, U.S. Cuban Refugee Program, Social and Rehabilitation Service, Department of Health, Education, and Welfare, says 9. 
second Cuban refugee program. Twenty seven candidates (joined shortly by three other persons), equally divided between lawyers and teachers, arrived in Forest Grove to begin training to teach Spanish in United states public school systems. "BY the Fall of 1965, 28 had received their Bachelor of Arts degrees and had secured teaching positions in California." 17

According to Dean Baldwin, Mr. Tony Micocci, a Federal official involved with the Educational Refugee Program, deserved great credit for the establishment of plans such as the one at Pacific. Expansion of Pacific's program to include teacher retraining grew out of a dinner conversation between the two men, but Reese, Ellis, Paul Menegat, director of teacher placement, and Dr. Meredith McVicker, head of the education division and Dean of the graduate school played vital roles in the programs' successes.

Pacific's spanish program copied the structure of the University's usual teacher education plans. Courses in educational psychology, human development, and methods were, however, supplemented by careful language monitoring and an American life course. Dr. McVicker recalled "excellent interaction" between Cuban and other members of the Pacific community, including numerous examples of extra help being offered to refugee students. "We did a very good job," 
McVicker averred, citing a successful placement record and the warm correspondence that continued for years after the cubans left oregon. ${ }^{18}$

Oregon's Catholic Archdiocese played a financial role in Pacific's effort, by helping to fund student housing. Father Park praised Reese's careful management of Federal dollars. Unlike several similar projects which spent all available monies before students found work, Pacific saved a portion of each student's allocation. Some participants complained to Reese, but his foresight was rewarded with interest, when this fund paid for the placement trips to California that netted jobs for many graduates. ${ }^{19}$

Private industry also contributed to Cuban assimilation in Portland. Paul Nagel's contact with Rafael Cancio in June of 1962 occurred partly under the aegis of Catholic Relief. similarities in political and cultural perceptions became apparent immediately, fueling the partnership and the continued employment of Cuban-Americans and other Hispanics through the end of the 1980s. ${ }^{20}$

Another essential ingredient in the transition process was provided by government agencies. According to Father

18 Conversation with Dr. Meredith McVicker.

19 Interview with Father Park.

20 Conversation with Paul Nagel, interview with Margaret Godfrey. Omark Industries, Hyster, and Barker Furniture were also mentioned as local businesses which proved helpful to the emigre community. 
Park, Oregon's Cuban welfare effort received praise at a national conference, an event which proved a pleasant surprise to local officials. This positive notice negated the fact that "local feeling (about adding outsiders to welfare assistance) was not favorable, to say the least," and encouraged further negotiations between Park and county welfare personnel. An agreement was reached which created an unofficial pool of ten cuban refugees on county welfare rolls: as one name was removed from the list another was added. Turnover was rapid due to the migrants' aversion to welfare and their determined approach to the problem of obtaining employment. 21

In July 1962 Oregon's Bureau of Family Services received a copy of an HEW paper outlining financial assistance procedures for resettled Cuban refugees. Director Kathryn D. Goodwin's cover letter which accompanied the paper on its rounds through the appropriate state agencies discussed "two basic changes authorized...to step-up the rate of resettlement from Miami." These were a "transition allowance" designed to "increase the rate of resettlement" by allaying fears of

21 Interview with Father Park. Robey Eldritch, one of the county welfare officers assigned to handle cuban cases, recalled the acute embarrassment displayed by this particular group of recipients, and the nearly unanimous expectation of a quick return home. He further remembered that those cubans who came from wealthier backgrounds were less demanding than their poorer compatriots, who also often created fanciful versions of past experiences on the island. This observation was reinforced in other conversations. 
refugees and sponsors alike, and authorization "that financial assistance may be provided to any resettled cuban refugee in the place of resettlement if he is in need and otherwise eligible."22 Table III is a compilation of available resettlement figures for oregon drawn from different sources.

\section{TABLE III}

RESETTLEMENT FIGURES FOR OREGON

1. 15 February 1961-20 April 1963

(Committee on the Judiciary report, June 1963)

2. June 1961-30 December 1966

184

(Masud-Piloto, page 67)

3. January 1961-30 September 1968

(Resettlement Re-cap, December 1968, Cuban

Refugee Center)

4. through 1970

(Prohias and Casal, volume 1, page 113)

5. through December, 1972

(Prohias and Casal, volume 2, page 111)

6. through 31 October 1981

(Conversation with Cuban Refugee Center)

7. Marielitos through September 1982

(Office of Refugee Resettlement)

8. 1983-1989

(Conversation with Ron Spendal)

559

811

1,001

1,105

1,143

200

0

oregon Welfare's involvement with Cuban-Americans waned as the pace of arrivals slowed drastically near the end of the decade. By 1973, phaseout of the Cuban Refugee Program, for recipients who had lived in the United States for five years or more, was discussed in Executive Bulletins circulated through the Public Welfare Division. Congressional waffling created problems for state bureaucrats, but by the end of the

22 State Letter No. 580, dated 1 August 1962, signed by Kathryn D. Goodwin. 
year it was clear that such cases were "found in so few caseloads," that only legal considerations applied in oregon. ${ }^{23}$ By 8 November 1974 the Cuban Refugee Program was eliminated from staff consideration. ${ }^{24}$

Governor Mark Hatfield's correspondence also reflected concern with cuban arrivals. The first exchange involved the question of placing cuban doctors, and oregon's laws made the Governor's response unhelpful. ${ }^{25}$ Hatfield's appointment as Vice Chairman of the Committee on Public Health and Welfare of the Governors' Conference created a small wave of refugeerelated paperwork in preparation for the 55th Annual Conference held in Miami during July, 1963. Extant are descriptions of the problem and pleas for help from Federal Refugee officials and Bishop James Carman of the oregon Archdiocese. The files also contain suggestions from Governor Richard Hughes of New Jersey, who chaired the Public Health and Welfare Committee, favoring the creation or reactivation of state refugee committees.

Nothing of substance resulted from the exchanges or the conference, although there is evidence of a rivalry felt by

23 Executive Bulletin number 73-61, 10 september 1973 and number 73-61A, 20 December 1973. See also Staff Manual, Volume II, Sections 2180-2182. 61.

24 See handwritten note on Executive Bulletin number 7325 Letters dated 13 December 1961 and 5 January 1962; memorandum dated 2 January 1962. 
Oregon's top elected official with Democratic Governor Albert Rosselini of Washington. ${ }^{26}$ Hatfield accepted an analysis suggesting that "it would be questionable for the state to be formally involved in a program," and the corollary recommendation "to lend your support to the voluntary efforts of Church World Service, International Rescue Service, etc. "27 The Governor submitted a resolution to the Conference which claimed that a "Eurasian dictatorship" dominated Cuba and urged "continued individual effort to see that these victims of tyranny find homes and job opportunities." 28 More substantial was a letter received by Hatfield from Andrew Juras of the State Public Welfare Commission just prior to the Conference. Juras outlined Welfare's record to date--service had been received by 49 family units with a total of 172 persons--and stressed Catholic Charities' contribution. Juras closed his correspondence by stressing language programs and the effort "made...to encourage and enable these people to become self-sufficient." 29

Like those resettled elsewhere, Oregon's emigres had arrived in their new homes with few material resources, and

26 Memorandum dated 23 February 1963; letter to Bishop Carman dated 27 February 1963.

27 Memorandum dated 23 February 1963. The omission of the much more important Catholic effort is surprising.

28 Proposed Resolution, 55th Governors' Conference.

29 Letter dated 16 July 1963. 
immediate issues of survival dominated their efforts during the first months in Portland. The quest for self-sufficiency constituted a central thread in their lives, and although state government had little to do with the process, there were clear signs of change by the end of the decade. Their relatively rapid mastery of these problems gave way to absorption into the mainstream and the emergence of notable individual efforts. The subsequent chapter details this successful adjustment. 
CHAPTER VI

OREGON'S CUBAN-AMERICANS:

EMERGENCE AND ASSIMILATION

Former attorney Ignacio Morales' call for a registration of Oregon's Cubans in early 1964 marked the community's transition beyond full-time emphasis on survival. ${ }^{1}$ Further evidence of movement beyond the fringes came in the Portland Board of Realtors' May 1964 honoring of the Agustin Enriquez family "for exemplifying the finest principles of home ownership, while displaying great personal sacrifice in order to achieve their goal of home ownership. "2 The family's rapid mastery of work, school, and language situations was atypical only in degree. It cannot be doubted that the first wave of immigrants to oregon embodied the analyses which posited a Cuban success story.

As Oregon's Cubans prospered, the notion emerged of establishing a meeting place where conversations and more formal social events could occur. Such clubs, or liceos, are an old Cuban tradition with roots on the island and in the

1 The Oregonian, 9 January $1964, \mathrm{p} 17$.

2 Oregon Journal, 28 May 1964, p 5. 
early Florida communities alike. ${ }^{3}$ The small and relatively homogenous nature of Oregon's arrivals rendered moot a typical pattern of establishing different liceos for different social, economic and racial groups. Thus, in January 1968 The oregonian reported the opening of the Liceo Cubano in a building located at 3279 southeast Hawthorne street, ${ }^{4}$ an event which followed a well-attended meeting at the home of Jorge and Herminia Arias. 5

The Liceo endured for approximately ten years, and nurtured a sense of community among many in the exile population. Aid to newly arrived paisanos was focused through the Liceo, while organized events, such as weddings and birthdays, began to be held at the Hawthorne building. The island tradition of giving gifts to the New Year's first-born child was transferred to Oregon beginning in $1969 . .^{6}$ The Liceo entered a successful softball team in city league competition, twice winning championships. Festivities from early years are remembered fondly by Portland's Cuban community, and

3 see James w. Covington, "Ybor city: a Cuban enclave in Tampa," in Carlos Cortes, editor, The Cuban Experience in the United States, New York, 1980, pp 87-88; José Rivero Múniz, The Ybor city story, Tampa, pp 16,38 .

4 The Oregonian, 29 January 1968, pp 19.

5 Interviews with Herminia Arias, José Calderon, Jr., and Daniele Fajardo, Jr.

6 Oregon Journal, 27 January 1969, section 2, p 1; The Oregonian, 29 January 1969, section 2, p 11. 
persisting long-term relationships were fostered by the Liceo Cubano.

Several factors contributed to the club's closing. Internal cohesion lessened as younger Cuban-Americans moved into the wide array of activities available in the metropolitan area. Meanwhile, tensions developed within the older, core group which made the liceo function. Inevitably, a small cadre assumed responsibility for organizing and carrying out activities. These people began to feel resentment about time and financial burdens, while more peripheral members resented their out-group status.

By late 1969 Liceo members were attempting to give something concrete back to Portland by offering free Spanish classes to any interested oregonians. The program achieved some success, and the genuinely good motivations that empowered it account for the baffled and somewhat nettled tone that marked 1989 descriptions of the Liceo's demise. Sometime in the mid-1970s an elderly gentleman, who had been enrolled in classes, filed a complaint with the fire department about occasional overcrowding and insufficient exits at the Hawthorne address. Officials upheld the complaint, and in light of the expenses necessary to bring the building up to code the Liceo's doors were permanently shut.

Coverage of escapes from communist tyranny continued throughout the ensuing years, but oregon's Cuban community also received other notice. Jefferson High School's selection 
of a Cuban emigre, Ana Maria Enriquez, as Rose Festival Princess, was followed by her coronation as Queen of Rosaria in June of 1967. Descriptions of the event made significant mention of Queen Ana Maria's background, especially the family's escape from tyranny, while her obvious popularity underscored the success of the Enriquez family. ${ }^{7}$ The following september newspapers reported her naturalization. ${ }^{8}$ Six of the ten Enriquez remain in the metropolitan area, and the others have also established themselves in the Northwest. Agustin Enriquez, Jr., the family's oldest son, runs the Combat corner on North Lombard, and his lively intelligence reflected their successful establishment in the United states. Newspaper articles traced the family's mass movements from Havana to Jamaica to Miami to oregon." Enriquez detailed his father's disillusion with the Rose Festival's administration of Queen Ana Maria's schedule, and his decision to apply traditional Cuban notions about proper chaperoning to Rosaria. Given little choice, the Association complied, and an altered system has been in effect since. Not coincidentally in Enriquez's mind, Rose Festival officials claim that the "very rare" event of losing track of a Queen,

7 Oregon Journal, 3 May 1962 , p 4; 6 June 1967, p 1, p 8; The oregonian, 4 May 1967, p 1; 6 June 1967, p 1.

8 oregon Journal, 26 September 1967, p 1; The oregonian, 27 September $1967, \mathrm{p} 11$.

9 Enriquez family archival newspapers: Avance, 24 March 1961, various Miami Heralds, The Oregonian, 6 May 1962, p 30. 
namely Ana Maria, occurred sometime after the end of her reign in June of 1968 .

Headlines trumpeted the refugee background of Franklin's 1982 Princess, Maria Pérez, whose family arrived in Portland in $1970 .^{10}$ It is thus interesting that the cuban heritage of the 1989 Queen, Deanna Connell of St. Mary's, was ignored by the newspaper." Likely, the omission accurately reflected the reporter's perception that this information, although tendered by the family, no longer constituted a newsworthy aspect of the story. The decision was somewhat unfortunate from a historical perspective, given the fact that queen Deanna's grandparents were the Maribonas, and that her mother's 1955 arrival as a child in Portland lent the Queen's background a rather unique visage.

A special HEW award bestowed on new Oregonians in 1969 and 1970 further illustrated the community's progress. Agustin Enríquez and Rafael Cancio both received citations in 1969 "for valuable cooperation rendered the Cuban Refugee Program and for extraordinary and meritorious performance of civic duty in the United States of America." 12 The rapid success of each man and their respective families served as the basis for the honor, two of eleven such made nationwide.

10 The Oregonian, 3 April 1982, p Cl.

11 The Oregonian, 8 April 1989, p D1; 3 June 1989, p 1. 12 Oregon Journal, 7 February 1969, p 4. 
The following year the same citation (now identified as the Lincoln-Marti Award) went to Mr. and Mrs. Daniele Fajardo, whose own swift establishment in Portland had been accompanied by a demonstrated concern for needy cubans. ${ }^{13}$

Early in the 1970s a group of Latin American businessmen and professionals gathered at the Purple Earth Tavern in Northwest Portland about once a month for informal luncheon meetings. Sometime early in 1973 a more formal structure was suggested, and as a result the group formed an organization called the Latin American Chamber of Commerce. Members from outside the Hispanic community were invited to join, and the luncheons continued for some time, focusing on expansion of Portland's business contacts into the rest of the hemisphere. ${ }^{14}$ Records at the Portland City Archives include correspondence to various city officials from an ideologically-oriented organization called the committee of Eighteen Spanish Speaking Nationalities. The documents, dated from 1974 to 1976, featured stridently anti-communist sentiments and assurances that the committee itself was free from any such affiliation. Letters submitted to various recipients concluded with signatures accompanied by countries of origin. The listings indicated cuban primacy in the Committee's hierarchy, featuring the influence of its founder

Oregon Journal, 13 February 1970, p 2.

14 Interview with Daniele Fajardo, Jr. 
and chief organizer, Obdulio F. Fernández, who was known as "Mayoria" in the community. The oregonian reported Fernández's status as a delegate to El Congreso de obreros in New York in 1972, mentioning his "dream of free Cuba" a quote about the danger of President Nixon's "socialist rapprochement." ${ }^{15}$ Fernández disappeared from oregon sometime after the Committee's demise, but was remembered as a strongwilled and ultra-conservative man who embodied the fiery opposition to Fidel Castro and communism prevalent elsewhere among Cuban-Americans.

This explicitly ideological public chapter in oregon's Cuban story is strangely isolated and brief. Succeeding Hispanic political and organizational efforts focused on concrete concerns and reflected a diminishing cuban role, in line with growing presence and activity by arrivals from the rest of Spanish America. Further, the Cubans' generally successful assimilation both reduced the community's need for assistance and also its access to purely Hispanic-organized aid efforts.

The Committee of Spanish Speaking People of oregon (COSPO), was founded in 1976 largely through the efforts of Luis Alvarez, son of Rina Alvarez who served as houseparent for the Unaccompanied Children's group home. Cospo and Mr. Alvarez remain the most enigmatic elements of the Cuban 
community's public history. José Calderon, Jr., stated that cospo was "piggy-backed" onto the Eighteen Nationalities structure, but the younger men abandoned Fernández's political obsessions in favor of establishing a social service agency. ${ }^{16}$ cosPo created positive involvements with the comprehensive Employment Training Act, the Boy Scouts, and Burnside Community Council projects, among others. Mariel arrival orlando Fuentes cited a cospo English language program featuring the forceful presence of $\mathrm{Mr}$. Alvarez as the one outstanding example of first-rate assistance he received during a difficult adjustment to oregon. ${ }^{17}$

Contrarily, cosPo's record and reports about $\mathrm{Mr}$. Alvarez's activities are not entirely favorable. Financial irregularities, perhaps merely involving sloppy procedures, dogged the organization throughout its existence. An audit conducted in late 1981 by the Department of Public Utilities reported problems and seemed to have ended cospo's access to funding. Roberto Reyes Colon, formerly a cospo employee, summed up the critics' position in an extreme manner. His analysis saw irony in a Cuban-American presence, with its "historic white middle-class view," in the vanguard of the struggle to achieve rights for Hispanics.

Interview with José Calderon, Jr. 
Reyes Colon traced Alvarez's personal hand in frivolous expenditures, unpaid insurance claims, and use of cospo funds to buy personal luxuries. The bottom line, in Reyes Colon's view, was Alvarez's long-range scheme to set up a private cable business under the auspices of cospo. These efforts depended upon Alvarez's control of personnel: the hiring of an unqualified member of the cuban community as cospo's bookkeeper was cited by several sources as an outstanding example of such corruption. Reyes colon concluded by tracing a wider Cuban component in cospo's demise, implicating other persons and applying the terms "Cuban mafia," "poverty pimps," and "ruthless pigs," to their activities. 18

Armando Laguardia traced cospo's demise to the decision to put Alvarez in charge of day-to-day procedures, a move which also involved pushing Laguardia out of the operation. According to Laguardia, funding from United Way was nearly realized before the establishment of the new regime, and the subsequent "lack of policy expertise" and the absence of "structural and financial concerns" eventually doomed cospo. Laguardia characterized such an elevation of personality over system as typical of Latin politics, and said that this factor influenced his decision to refrain from involvement in specifically Hispanic efforts. ${ }^{19}$

Conversation with Roberto Reyes Colon. 
Another respondent, who like Reyes Colon and Laguardia had been involved with cospo, took a more paradoxical view of Alvarez's approach, seeing in him a combination of "consummate power broker" and "charming person." This perspective attempted to balance cospo's beneficial effects with Alvarez's emphasis on power. Ginny Bass, who has served in various governmental capacities for the city of Portland since her separation from COSPO, was adamant in her claim that no thievery occurred. For Bass, it was painful to see the unbridled use and pursuit of power juxtaposed to obvious talent and genuine concern. Bass placed the fiscal disaster within context of the preferential treatment afforded to the Cuban connection by Alvarez, a not illogical emphasis if power was indeed the focus of his concern. She acknowledged a loss of credibility suffered by herself and other early supporters of Alvarez, but philosophically characterized the period as a valuable learning experience.

Bass's historical overview was instructive. An important point in her analysis was the "statewide ignoring of Hispanics" that existed prior to Alvarez's "bursting onto the scene." The leverage he won delivered long-term benefits to the Hispanic community, even if the discreet case involved a lack of responsibility, delusions of grandeur, and accusations which used racism as a cover for improper procedure. ${ }^{20}$ 
It is important to note the subsequent history of the two most important groups later created to aid oregon's Hispanics: the Oregon Commission on Hispanic Affairs and the Oregon Council for Hispanic Advancement. The two OcHAs (this not coincidental duplication is another story) ${ }^{21}$ resulted from an increased concern with Hispanics' situation and also reflected a diminished cuban role in the public arena. The Oregon Council for Hispanic Advancement, although providing an extremely cordial reception, was unable to provide information about or access to anything cuban within the state. One Cuban sits on the board of the Oregon Commission on Hispanic Affairs, but the agency's 1989 biennial report contained no other reference to Cuban-Americans. Executive Director Eunice Goetz explained that the community's general success placed them beyond the pale of acute situations which were OCHA's primary concern. It also should be noted that community members' interest in sustaining such umbrella organizations

21 The Oregon Commission on Hispanic Affairs is a state agency whose public genesis occurred in the 1977 legislative session when a bill mandating its establishment died in committee. The bill was re-introduced in 1979 and did not pass on the floor of the House. In 1981 a Joint Black and Hispanic Commission was created, but the two functions were separated in 1983. OCHA appropriations rose from $\$ 31,631$ in the 1983 session, to $\$ 78,000$ in $1985, \$ 90,850$ in 1987 , and $\$ 101,167$ in 1989. The Oregon Council for Hispanic Advancement was privately constituted by a former oregon Commission on Hispanic Affairs employee, amid charges about typical Latin politics and self-serving motivations. Apparently the two agencies achieved some level of rapprochement in the late 1980 s. 
declined in direct proportion to their decreasing ability to exercise full control.

Several Cuban-Americans achieved a degree of prominence during the 1970s. Dr. Ricardo Sardina, who received his Doctorate in Philosophy at the University of Havana in 1949, arrived in Miami in 1962. He received Bachelor's and Master's Degrees at Pacific University between 1964 and 1968, also moving to the Modern Languages Department at Linfield College in 1966, where he remained until retiring in 1985. Sardina spoke at the official opening of the Liceo Cubano, and later created a program to provide education for "migrant workers with potential."22

Raúl Soto-Seelig was the most important public figure to emerge from Oregon's Cuban-American community during the first three decades after the Revolution. Born in Havana 15 May 1941, Soto-seelig, like many Cubans from every social class, supported the opposition forces allied against the Batista regime during the 1950s. Upon graduation from High School he went to Florida, Madrid and Paris for further study, in anticipation of pursuing practice of the law. Soto-seelig represented La Habana in el Congreso Hispano-Luso-AmericanoFilipino de Municipios in May of 1959, evincing support of the changes on the island, then returned to enter law school at

22 The Oregonian, 29 January 1968, p 19; 22 May 1971, p 12 . 
the University of Havana. ${ }^{23}$ Widespread disaffection with the Revolution's course came to include soto-seelig, and in 1960 he rather suddenly announced to his family an intention of leaving for the United States.

A year at San Jose City College, which was marked by success in student politics, brought soto-seelig's life to its intersection with oregon at the beginning of the University of Oregon's Fall Term in 1962. His undergraduate career included further achievement in local and national student organizations, and a "somewhat radical reputation" on political issues. ${ }^{24}$ After receiving his degree in economics, service with VISTA in New York City during 1965-1966 cemented a decision to continue in his family's legal footsteps, despite the difficulties involved in switching from the principles of Roman law. ${ }^{25}$ The University of Oregon law school prepared the former refugee for a steady climb in both his chosen profession, beginning with a term as Judge Philip Roth's clerk, and in politics. Soto-seelig worked for the Democratic party at the state, county, and precinct levels, and achieved his political and public acme with the resignation of Betty Roberts, the state Senator from District Ten, to accept a judgeship in mid-1977.

23 La Voz de Galicia, 24 May 1959, papers of Raul SotoSeelig.

24 Conversation with Pamela Hall.

25 Conversation with Elsa Seelig. 
Roberts' husband, Keith Skelton, was the Senator's choice as her replacement, but precinct-level opposition to the somewhat controversial skelton resulted in his being omitted from the five person list of nominees. ${ }^{26}$ supporters of the candidates--Soto-Seelig, Cindy Banzer, Allison Belcher, Jane Cease, and Jim Gardner --lobbied hard with the five County Commissioners in anticipation of the selection meeting scheduled for 26 september 1977. The nominations of Belcher, Cease, and Banzer died for lack of a second. Mel Gordon then placed soto-seelig's name on the table, and given that Don Clark had promised to support any candidate who received a second, Commissioner Dan Mosee's appropriate "con mucho qusto" assured the selection of Oregon's first Hispanic legislator. Local newspapers, while anticipating probable difficulties for soto-Seelig in retaining the seat during the 1978 election, praised the new Senator's abilities. The oregon Journal ran a favorable editorial, while The oregonian filed two positive evaluations of Soto-seelig's capabilities, describing him as a "low-key, self-contained individual, a multi-faceted man who often surprised people with the depth of his knowledge and ability." This story also contained an anecdote that illustrated a problem facing soto-seelig in the upcoming campaign.

A legal foe complained to the judge about difficulties involved in understanding him. The judge said that 'although $\mathrm{Mr}$. Soto-Seelig is 
sometimes hard to understand, he always knows what he is doing.

A spontaneous and memorable celebration occurred that evening at soto-seelig's home, attended by a wide variety of supporters, including numerous members of the Hispanic community. Soto-Seelig's eschewing of the pomp of a salem Capitol building ceremony for a Portland swearing-in in both English and Spanish before friends and family struck a note typical of his life.

The new Senator enjoyed a very short political honeymoon as both Banzer and Gardner filed for the May primary election. Gardner won the close three-way race, soto-seelig finishing third with $27.4 \%$ of the vote. He ran best in areas north and west of his Couch street home in precinct 3286 , and did particularly poorly in the southern and northeastern portions of the district. ${ }^{28}$

A specifically Cuban or even Hispanic factor is difficult to extract from the returns, but several pieces of evidence bear on the point. Soto-Seelig's unmistakable accent could not have helped him with conservative groups in District Ten. This characteristic, however, also hurt soto-seelig in more liberal circles. Pamela Hall mentioned the decision of the

27 The Oregonian, 27 September 1977, p D22; see also The Oregonian, 6 October 1977, p Cl; Oregon Journal 28 september $1977, \mathrm{p} 14$.

28 Soto-seelig's best showing came in precincts 3258, 3105,3112 , and 3128, while his worst areas were precincts $3245,3192,3205,4106,4115,3199$, and 4117 . 
Oregon Women's Political Caucus to endorse Jim Gardner as having arrived as an unpleasant surprise. Once the women decided to bypass the female candidate, who by all reports was one of three qualified people in the field, their rejection of Soto-Seelig seemed to be based on an "untrue assumption about his cuban background" which involved a mistaken perception that he possessed a "typical macho attitude."29 This view received support from Senator Jane Cease's remarks on the Senate floor on 4 April 1989:

Raúl then had to face a heated primary with both Jim Gardner and Cindy Banzer in it. Raúl lost and Jim won. I'm sure that there had to be some discrimination in that decision by the voters. ${ }^{30}$

Obvious disappointment over his loss did not dissuade Soto-Seelig from continuing careers in both public service and the law. His resume was still growing at the time of an untimely death on 17 November 1987 of Lou Gehrig's Disease. Detractors were nearly non-existent, as even very conservative Cuban-Americans, who often excoriated political opponents, were generous in their praise of Soto-Seelig's abilities and

Conversation with Pamela Hall.

30 Copy of Senator Cease's remarks from papers of Raúl Soto-Seelig. This sentiment was echoed by Armando Laguardia, who also called Soto-seelig a "brilliant tactician." José Calderon, Jr., noted that the senator commanded "wide respect," but pointed out that the cuban community was nowhere large enough to carry him. Frank Algeciras testified to SotoSeelig's willing provision of legal aid to Portland's Cubans. 
intentions. ${ }^{31}$ An often-cited aspect of his substance involved the intelligent and sophisticated women that shared his life: his mother Elsa Seelig, a sister Perle Morcate, wife Lynne, later companion Lindsey McGrath, and his daughter Elizabeth. oregon's decision not to comply with a 1975 Federal government request for model programs aimed at cuban and Haitian emigres assured that the flow of arrivals was effectively ended. ${ }^{32}$ Assimilation of the community, including official processes such as naturalization, continued throughout the decade. Table IV, which lists naturalizations of Cubans in the state after the Revolution, reflects this increased integration. The peak periods meshed with the high rates of arrivals in the 1960s, given the necessary waiting period. The relative frequency of continued naturalizations of Cuban-born residents of oregon throughout the late 1970s and into the 1980s illustrated the community's growing assimilation.

31 Two exceptions to this trend were Roberto Reyes colon, who mentioned Soto-Seelig's involvement defending Alvarez and cospo, and one cuban respondent who characterized him as a communist.

32 Conversation with Ron spendel. The reasons for Oregon's decision remained obscure inasmuch as records were already non-existent by the late $1980 \mathrm{~s}$. Economic considerations and the state's long-standing aversion to outsiders, especially foreigners, may be presumed to have been influential factors. 
TABLE IV

NATURALIZATIONS IN OREGON OF CUBAN-AMERICANS

$\begin{array}{rrrr}1961 & 0 & 1975 & 27 \\ 1962 & 1 & 1976 & 20 \\ 1963 & 0 & T Q 1976 & 6 \\ 1964 & 1 & 1977 & 18 \\ 1965 & 0 & 1978 & 20 \\ 1966 & 0 & 1979 & 13 \\ 1967 & 2 & 1980 & 12 \\ 1968 & 2 & 1981 & 8 \\ 1969 & 0 & 1982 & 9 \\ 1970 & 20 & 1983 & 11 \\ 1971 & 25 & 1984 & 8 \\ 1972 & 20 & 1985 & 9 \\ 1973 & 20 & 1986 & 7 \\ 1974 & 16 & 1987 & 7\end{array}$

Source: Statistical Yearbook of the Immigration and Naturalization Service.

TQ notation stemmed from fiscal year classification change instituted by the Federal Government.

Several other linkages also connected oregon to the island. As the possibility of a thaw began to appear in the latter part of the 1970s, Portlander James Carney became one of the first American businessmen to visit cuba with the aim of solidifying a commercial exchange. Representatives from the Cuban government told Carney that they desired "to go back to pre-1959 trade relations," and the Portlander's tour allowed him to see a successful side of "communism, Castrostyle." 33 Little seems to have come of the visit, as the rapprochement proved illusory. 
Later efforts have also been thwarted by the United states government's intransigence. Beginning in the early 1970s, Dr. M. E. Ensminger, founder of Agriservices Foundation of Clovis, California, attempted to establish an instructional program on the island. His efforts were frustrated through the opposition of the state Department and the 1980s Republican administrations. Dr. James oldfield of Oregon State University, a well-respected expert in the field of nutrition, was asked by Ensminger to head this part of the program. Ensminger, who continued to press his plan through the ensuing years, averred that although he strongly disagreed with the ban, as a "loyal American" he would not violate government policy, but did intend to continue working towards a change in the official American view. ${ }^{34}$

In August of 1978 another Portlander, Cliff McRary, ended a four year stay on the island that began when he hijacked a fishing boat from Key West in July of 1974. McRary's family alluded to personal and financial worries as the cause of his action. McRary's time in cuba included seven months in prison and proved a less than satisfactory way to deal with his problems. Upon arrival at Customs in Miami, he was arrested by the FBI and later indicted in Florida. ${ }^{35}$

34 Conversation with Dr. M. E. Ensminger.

35 The Oregonian, 3 August $1978, \mathrm{p}$ B3; 6 August $1978, \mathrm{p}$ G10; 8 August 1978, p A11. 
Resettlement trickled to a virtual standstill in the state during the second half of the 1970s. The decision not to participate in any federally-funded relief for cuban migrants continued after the Mariel boatlift. Once again private agencies --Catholic Charities, the Tolstoy Foundation, and Ecumenical Ministries of oregon--attempted to resettle arrivals. The Tolstoy program involved 33 individuals drawn from high-risk groups, most of whom were immediately placed in alcohol and drug programs. The effort was a total failure: by May of 1982 a large number had returned to Miami, while it was also reported that seven Tolstoy clients were being held in Multnomah County or Rocky Butte jails. ${ }^{36}$

Protestant efforts focused on Ecumenical Ministries of Oregon, but the local group's "loose connection" to national agencies contributed to a disorganized response. Lenore Frimoth recalled that the appeal for resettlement "came and went so fast" that it was "almost an invasion."37 EMO officials, laboring under the further handicap of Oregon's refusal to ease the new arrivals transition by allowing the use of any available Federal funds, did little to encourage resettlement.

The outstanding response generated by this approach was that of Harold and Wilma Magee of the Friends church in

36 Willamette Week, 25-31 May 1982, p 1.

37 Conversation with Lenore Frimoth. 
Newberg. The Magees, who had previously worked with Laotian refugees, said "OK" when EMO called and agreed to sponsor six Cubans. Magee recalled English language aid lent by cospo and spoke highly of the Marielitos. The new arrivals told horror stories of their treatment by the regime, and especially of the brutality, including murder, afforded some at the port of Mariel. Only two of the Magees' group stayed in the Portland area. 38

One source listed 172 resettlements attempted by catholic Charities. 39 Agency records are incomplete, but it appears that this total did not include 30 persons admitted directly into an alcohol treatment program after pressure was applied by the United States Catholic Conference.40 Like their predecessors from previous decades, some of the Catholicsponsored refugees have adjusted admirably to life in Portland. The outstanding public success within the catholic effort was the decision by senator Bill McCoy and his wife, County Commissioner Gladys McCoy, to accept Ricardo GuerraCastellanos from the camp at Fort Chaffee. The Mccoys were responding to a call from "Father Francis Kennard, an oregon

\footnotetext{
38 Conversation with Harold Magee.

39 Willamette Week 25-31 May 1982, p 1.

40 Interview with Father Park.
} 
diocesan priest on temporary assignment with the U.S. Catholic Conference at Ft. Chaffee. $"{ }^{41}$

By and large, however, it is apparent that the program was a failure. The generally negative comments from previously-arrived cubans that greeted questions about the Marielitos confirmed this conclusion. The lack of substantial federal or other aid, cospo's fall, and the arrivals' own background all contributed to the problem.

A story in Willamette Week from 1985 summarized the situation. The article focused on marginal arrivals and depicted a stark contrast with the 1960s arrivals. The writer quoted Margaret Godfrey on the preponderance of "Burnside-type people." Noted homeless crusader Michael stoops noted that the Cubans "were not very trusted by other people and there's a lot of hostility towards them." Governor victor Atiyeh's continued refusal to participate in the federal program contributed heavily to the problem. ${ }^{42}$

The Oregonian and oregon Journal coverage of the Marielitos concentrated on old themes. Stories stressed Cuban government repression, happy reunifications, and language problems. Neither the problems suffered by the new arrivals, nor the successful adjustment of new or previous cuban-

41 Catholic Sentinel, 9 January 1981, pp 1, 19.

42 Willamette Week, 13-19 June 1985, p 3. 
Americans found expression in the metropolitan dailies during the 1980s.

In 1985 the Federal Government proceeded with its plan of granting permanent resident status to the 1980 CubanHaitian entrants. This constituted significant news for Oregon's scattered Mariel community. Godfrey took charge of registering the entrants, and helped them submit properly prepared forms to Immigration authorities. The 120 or so names on this list probably provided a fairly accurate count of the number of new Cubans living in the state in 1985.

The alienation between the older community and the new arrivals became apparent when an effort was made to contact Marielitos living in Portland. Most established Cubans wanted little to do with post-Mariel refugees, although under closer questioning there was generally a grudging admission that the majority are "buena gente." The difficulty in finding Marielitos presumably lies in their separation from many of society's mechanisms, not surprising for a group still struggling to achieve assimilation. Further problems surfaced on the few instances when contact with the community occurred. Respondents demonstrated great reluctance to talk in depth, and a growing tone of paranoia, sometimes including the implication that the questioner had CIA connections, marked contact. One successful Mariel interview will be included in the oral histories discussed in the next chapter. 
OREGON'S CUBAN-AMERICANS :

THE ORAL HISTORIES

The daily lives of most private citizens only occasionally intersect with the wider public processes whose story normally constitutes historical and journalistic writing. The value of events and evaluations drawn from personal experience lies not only in their ability to verify and amplify public histories, but in the delineation of which incidents and ideas matter to individuals. One can appreciate the favorable view taken by oral historians of information stemming from direct interviews.

No form of evidence, however, is bias-free, thus the assortment of individuals and topics covered in this chapter reflects subjective choices. Oregon's Cuban community does not constitute an elite in the traditional sense of the term, but persons interviewed were a relative elite within the group of Portland arrivals. The chain of contacts began with University and Catholic Charities sources, and accessible Cuban-Americans included only those who managed to adjust successfully to the Northwest. Further, the interviewer, although capable in Spanish, remained subject to advantages and disadvantages appropriate to outsider status. 
oregon's established community is an able and intelligent group, unsurprisingly in light of the obstacles they faced upon arrival in North America. Any student of Cuban history would have relished the opportunity to converse with these refugees on a virtually unlimited number of appropriate topics. As perhaps the most conservative member of the interviewed group stated, "cada persona tiene su idea"--each person has his or her view--and the questioner was treated to a variety of interpretations regarding the major figures and incidents in Cuban history since the Spanish-American War. ${ }^{1}$

This same person was not alone in his veneration of General Machado, while praise for more ancient paragons--José Martí, Antonio Maceo, and Máximo Gómez--arrived quickly from all Cuban-Americans educated on the island. The diversity of opinion concerning Machado also pertained to all of the major figures who arose after the General's failed last ditch efforts to forestall personal disaster. Batista, Grau, and Prio were variously lauded and excoriated, although Grau, despite receiving blame for the rise of gangster politics in the early 1940s, was nonetheless preferred to Prío, who succeeded him. Senator Eduardo Chibás, whose oratorical skills and 1951 dramatic suicide helped discredit the alreadystrained political system, received varied, although generally negative reviews.

1 Interview with Jesus Guerra. 
Fulgencio Batista, a more recent figure, and the pivotal player in the successful Revolution engineered by Fidel Castro emerged as the most controversial of Cuba's twentieth century public men. Virtually every local Cuban-American expressed preference for Batista over Castro, but most of these made clear their distaste for the methods employed by the former sergeant after his 1952 coup. Responses to Batista ran the gamut from outright support, to mixed evaluations which tried to balance his regime's corruption with the relative freedom that yet persisted, to various adversarial positions. Emilio Rodriguez frankly stated his lifelong opposition to Batista's party, explaining concisely, "I was a worker."2 others of oregon's Cuban-Americans fought with the forces trying to dislodge the dictator, only later perceiving a greater danger in Fidel Castro's policies.

Anti-communism remained virtually a sine qua non in the community's political ideology. Allusion to communist influence often sufficed as explanation for opposition to Fidel or any specific policy. However, these assertions lacked the virulence or all-encompassing obsession with a shadowy threat that marks some versions of the approach. Castro himself was despised beyond redemption by most of the state's Cuban arrivals, and specifically credited with drug trafficking and wholesale murder of his opponents. 
widespread and interesting example was the belief that he personally murdered revolutionary hero Camilo Cienfuegos, whose death was officially attributed to poor weather conditions which caused his small plane to crash.

Camilo received generally high marks from the Portland community, while Fidel's only rival for least-liked Cuban was his brother Raúl. Some respondents damned che Guevara by placing him in the communist category, but others separated him from the gratuitously destructive natures they attributed to the Castros. The name of Huber Matos, a late-1980s exile to Miami after twenty five years in prison, generally brought praise for his early opposition to Fidel's authoritarian approach .

Like many on the island, Portland's emigre cubans left because they felt adversely affected by changes designed to alter traditional social and political relationships. No one experienced short-term benefits from the decision to emigrate, rather the stigma attached to gusanos led to problems with neighbors and authorities alike. A strict inventory system which the government applied to all of the goods belonging to would-be migrants contributed to the long wait which most of them endured before receiving proper legal clearance to depart on one of the KLM or Pan Am flights.

Two interview subjects left the island due to duress resulting from active involvement in the movement opposing the new regime. Frank Algeciras was jailed on the eve of the Bay 
of Pigs invasion, although concrete evidence of his involvement in counterrevolutionary activities never surfaced. Algeciras' release from prison occurred because the cell system favored by the government's opponents remained intact. He was able to board a jet for Miami in August 1961, although his final hours on the island were spent dodging a potentially dangerous G-2 agent in the Havana airport. ${ }^{3}$

Daniele Fajardo, Jr., joined the fight against castro when he and two other sixteen year old friends formed a sabotage unit aimed at military and government installations. One successful bombing led to a second mission in June of 1961. That attempt ended disastrously after Fajardo noticed smoke rising from the plastic cap used to cover the acid fuse which had been placed in the shirt pocket of one of his friends. Before his companion could toss the unit away it exploded, severing the right hand, and precipitating a wild scene in front of the intended target. Significantly, passers-by attempted to shield the injured youth, but his actions, resulting from overwhelming shock and pain, led to immediate capture in a nearby liceo.

Fajardo and his other friend, after failing in attempts to aid their partner, returned home. Fajardo's companion said nothing to his family and was taken out of his house and into custody by police agents the next day. Both of the

3 Interview with Frank Algeciras. 
apprehended youths spent many years in prison before being allowed to emigrate to the United states. Fajardo's father, however, upon being appraised of the situation, sent his son into the underground network, where the younger man endured for twenty one days, passing through seven safe houses, before finally emerging near Guantanamo.

After about seven weeks at the base, Fajardo and three other escapees were ushered into an amenity-laden room hidden behind a closet in a lieutenant's office, and were then flown to Miami. Making contact with exile organizations dedicated to the overthrow of the Castro government proved easy, and Fajardo devoted the next period of his life to this aim. His experience grew to include a clear view of the exile-cIA link, a sabotage trip back to the island, time in an Everglades training camp, and discharge from a special program at Fort knox after the easing of the missile crisis. A powerful "patriotic air" gave way to reality and questions of survival, and Fajardo decided to settle with his mother who was living in oregon. Fajardo, Sr., unable to leave the island immediately due to his son's activities, bided his time before eventually rejoining the family. ${ }^{4}$

While Fajardo's tale is unique, Cuban-Americans who resettled in Oregon during the 1960s and 1970s included people who made use of nearly every available avenue off the island:

4 Interview with Daniele Fajardo, Jr. 
male and female minors in the Unaccompanied Children's Program, families and individuals flying via Jamaica or directly to Miami, Camioroca arrivals, people who went first to Spain, Mexico, or Central America, those whose legal status prompted improvised small craft journeys to the Florida Keys, and Marielitos. Most stayed only a short while in southern Florida, although the high rate of return to Miami that occurred over the years, and the favorable reviews of "Little Havana" offered in some conversations, spoke clearly of the powerful linkages to the city felt by Cuban-Americans in oregon and throughout the nation.

Initial impressions of an oregon so distant that it seemed like a foreign land remained strong in the minds of the transplanted Cubans: "I had no idea where oregon was,"-Consuelo Lightner;" "I didn't even know that Portland existed,"--Herminia Arias; ${ }^{6}$ "cowboy connection,"--Anthony Laguardia. ${ }^{7}$ others chose oregon after receiving a recommendation from by a friend or family member. José Calderon, Jr., remembered that any free choice seemed better than forced adherence to resettlement requirements laid down by government officials. ${ }^{8}$

5 Interview with Consuelo Lightner.

6 Interview with Herminia Arias.

7 Interview with Anthony LaGuardia.

8 Interview with José Calderon, Jr. 
Reunions figured prominently in the coverage afforded the community in local newspapers, and several interviews included stories of rejoined families. Emilio and Consuelo Rodríguez kept their relationship alive through a period of separation which entailed a stay in spain for him, before reunification with sister Elena Rodriguez in Portland. Consuelo arrived later and the couple were married in Portland. 9 By the time of the 1980 Census there was evidence of the community's dispersal throughout the state as is reflected in Table $\mathrm{V}$. The drop in the Multnomah county figures also demonstrated the return to warmer areas that was occurring among older arrivals.

\section{TABLE V}

OREGON'S CUBANS: RESIDENCE BY COUNTY (CUBAN-BORN IN PARENTHESIS)

1970

Clackamas

clatsop

Coos

Jackson

Lane

Linn

Marion

Multnomah 500

Wasco

Washington 146

15

19
1980

(88)
Benton 29

Clackamas $\quad 78$

Coos

Deschutes

Douglas

(15)

(25)
Jackson

Lane

Lincoln

Linn

Marion

Morrow

Multnomah

Polk

Tillamook

Umatilla

Washington 70

(6)

(41)

(4)

( 6$)$

(24)

53

1

496 (340)

3

29

7

(11)

Yamhill
8 (2)

9 Interview with Consuelo and Emilio Rodriguez. 


\section{TABLE V}

OREGON'S CUBANS: RESIDENCE BY COUNTY

" (continued)"

Source: United States Census, 1970--Table 119, 1980--Table 59

Appreciation of help received from Catholic Charities or Protestant organizations was unanimous, although certain inevitable strains between individuals arose. The quality of aid tendered by Father Park, Margaret Godfrey, and Cecelia Barecevich is apparent from the interviews, even though financial restraints limited the possibilities and forced a difficult adjustment period on the early arrivals.

Language problems were nearly ubiquitous, although children made much more rapid strides in mastering English than did their parents. Several respondents shared humorous incidents growing from their imperfect grasp of the language and culture. Chani Perera recalled a mix-up between the words soup and soap, quite distinct words in Spanish whose similarity in English brought her to grief. ${ }^{10}$ Her daughter, Consuelo Rodríguez, detailed a story concerning a mistakenlybought baking hen which she attempted to fry with memorable results. ${ }^{11}$

10 Interview with Chani Perera.

11 Interview with Consuelo Rodríguez. 
Most of this portion of the Cuban-American community retained fond memories of the Liceo Cubano, and a number of them were part of the force which made it operate. An interesting exception was provided by Rafael Cancio, Jr., who recalled implications of his father's independent approach. The Cancios left Miami largely due to the Batista-like atmosphere in the cuban barrio, a distaste which carried over into oregon. The Liceo's social atmosphere repelled the elder Cancio, and the family had little contact with the club's activities. ${ }^{12}$ Agustin Enriquez, Jr., characterized his family's participation in Liceo events as limited to "special occasions," and attributed the rare friendship which existed between the senior Cancio and Enriquez, Sr., partially to a shared view of the emigre cuban community. ${ }^{13}$

Questions about santeria yielded interesting results. Some respondents were offended at the association, making clear their reluctance to pursue the topic. Others took a somewhat deeper view, and investigated the subject to the questioner's benefit. African and Catholic roots were mentioned, as was the rumored arrival of the practice on the island with economically-motivated Haitians. Some persons took the analysis further and pointed to parallels in the

12 Interview with Rafael cancio, Jr.

13 Interview with Agustin Enríquez, Jr. 
United states and worldwide, citing traditional North American superstitions and new age practices as equivalent phenomena.

The success and virtues of the contacted portion of the community were patent. Women and men alike from the two older generations of Cuban arrivals successfully bridged the gap between island and mainland. The objective successes achieved by men such as Soto-Seelig, the Calderons, Alvarez, the Fajardos, the Enriquezes, Rodriguez, Arias, the Cancios, Algeciras, Laguardia, and by women such as Berta Feran, Consuelo Lightner, and Sorina Rio Seco, were buttressed not only by the successful familial relationships that have resulted from concerned homelives, but also by direct contact with the individuals.

By the 1980s it was becoming clear that the assimilation achieved by the community resulted in a severing of connections with the island and cuban cultural traditions. Spanish was being spoken less and less frequently among younger generations, and interest in historical figures, traditional culture, food and beverages, such as cafe cubano, or even in visiting the island were waning. Contacts among many Cuban-Americans diminished to formal events, such as weddings, funerals, or birthdays, although it is apparent that older survivors relied heavily on the remaining pool of paisanos for social contact. Some exceptions, to be sure, existed among children born in the United states: in fact virtually every family had a younger member whose interest in 
the island led to being labeled "the Cuban son, daughter, or grandchild." The romantic interest evinced in another cubanAmerican by one of José Calderon, Jr.'s, children also ran counter to the trend in the younger generations of increasing separation from things cuban.

The lessened pace of arrivals during the 1970s, and the increasing cultural, social, and economic distance felt by earlier emigres from people on the island contributed to the relative disassociation from Mariel and other post-1980 immigrants. Queries about the Marielitos usually brought initial negative responses, subsequently qualified to include the observation that every group has good and bad elements.

Even Orlando Fuentes, the one interviewed Marielito, shared the view that most of Portland's Mariel migrants had been "mala gente que fuma y beba"--bad people who smoke and drink. ${ }^{14}$ This notion of a drug connection was not limited to Fajardo, Father Park confirmed the problem, and it was also articulated in the city's underground community. ${ }^{15}$ The reaction of the established cubans to this presence also contributed to the fact that by the late 1980s there existed little contact between them and later arrivals.

${ }^{14}$ Interview with orlando Fuentes. Fuentes' cousin, Pablo Fajardo, who had arrived the previous week from the island presumably making him the state's newest Cuban-American, sat in on the interview.

15 Interview with Father Park. 
One exception was Becerra's Spanish Foods on Northeast Glisan, where immigrants from throughout Spanish America congregated to shop and socialize at the store run by a family who began to arrive in oregon in the 1960s. The writer pursued a number of conversations bearing on the island situation and other matters within the Cuban-American community. Some persons refused to give their names, but freely offered lessons on life under castro and extensive advice on the proper North American response. A stridently anti-communist tone dominated most of these diatribes, but the source was valuable for the contact maintained by the Becerras and various customers with family members still on the island and in Panama. These respondents graphically reinforced the negative view of life under Fidel offered in the interviews. Tales of torture and deprivation dominated the monologues.

Orlando Fuentes, who spent time in Fort chaffee before bringing a determined and hard-working ethos to Portland along with his working-class background, agreed with this analysis. "Los ricos solamente comen bueno,"--only the rich eat well-he offered, before naming oppression, specifically human rights violations, as the island's other constant. Fuente's view of figures from the island's past was largely confined to characterizing Machado, Grau, Prio, and Batista as "asesinos." 16 
During the course of the research, the Becerras managed to sell their store and realize a long-standing desire to return to "Little Havana." climate and cultural concerns were primary in this decision, which repeated the example offered by many other early arrivals to Portland. José Calderon, Jr., estimated that from a peak of around one hundred families, there probably remained between fifty and sixty in the area in 1989. ${ }^{17}$ The growth in Oregon's Cuban population since the Revolution, as demonstrated in Table VI, has not continued during the 1980s, and it would not be shocking if the 1990 census showed a diminution in the city's Cuban-American population.

TABLE VI

PERSONS OF CUBAN BIRTH AND PARENTAGE IN OREGON

$\begin{array}{lccc}\text { year } & \text { birth } & \text { parentage } & \text { total } \\ 1960 & 44 & 108 & 152 \\ 1970 & 414 & 275 & 689 \\ 1980 & 562 & 412 & 974\end{array}$

SOURCE: 1960 Census, Detailed Characteristics of the Population, Table 139

1970 Census, Detailed Characteristics of the Population, Table 141

1980 Census, Detailed Characteristics of the Population, Table 63

Table VII makes it clear that even by 1980 there were very few oregonians who had arrived recently from the island. The relatively high number of pre-Revolutionary immigrants is surprising to the point of raising some doubts about the test

17 Interview with José Calderon, Jr. 
results. Certainly, few of the available members of the local community had contact with these long-time residents in the United states.

TABLE VII

CUBAN-BORN AND YEAR OF IMMIGRATION

Total 1975-80 $1970-74 \quad 1965-69 \quad 1960-64 \quad 1950-59$ pre-1959

$\begin{array}{lllllll}562 & 0 & 73 & 251 & 160 & 31 & 47\end{array}$

298 naturalized, 264 not citizens

Source: 1980 Census, Detailed Characteristics of the Population, Table 195.

Some of the remaining members of oregon's Cuban-American community contemplated a return to Miami, or a move to another warm climate which also offered a cultural support group, principally Los Angeles. ${ }^{18}$ Reactions to "Little Havana" and the entire Southern Florida Cuban enclave were mixed, although even those who would not consider living there maintained ties of family and friends, and most visited the area at least semi-regularly.

The Rodriguez family offered an intriguing view of the combination of American and Cuban cultures. The absent eldest child was described as the Cuban daughter. The second and third children, Eileen and Eduardo, evinced little interest in Cuba compared to the more Americanized activities that fill their lives. Eduardo, who was born in Vietnam and adopted by 
the Rodriguezes, demonstrated good language skills in adhering to household regulations demanding the use of Spanish, and shared his father's and the interviewer's interest in baseball. A strong connection to various items from American culture dominated his time. Family emphasis on education reflected a traditional cuban concern, whose impact was apparent in Eileen's work. Discussion of this and chaperoning revealed the compromise between American and island ways effected by the family. When the topic was turned to "Little Havana," where the large presence of family and friends had prompted numerous visits by the Rodriguezes, Eileen offered an instructive observation: "You go around thinking this is a strange family, and then you go there and everyone is the same way." 19 The transition undergone by this able family unit was an apt metaphor for the wider process.

The majority of the established community considered themselves oregonians and were free in their praise of conditions in the Northwest. Even these people had fond remembrances of the idyllic climatic conditions on the island, but events of the past thirty years have ended considerations of a permanent return. For many, the looming figure of Fidel Castro cast a long shadow over any thoughts of a return. others had visited the island, but shared with those who have 
not a distaste at the notion of giving any financial assistance to the hard-pressed cuban regime.

Consuelo Lightner and Consuelo Rodriguez both told of repeating nightmares about being trapped on the island, a thought which found conscious articulation by many who had contemplated a return to the land of their birth. The paradisiacal qualities of the island, and the powerful ties felt by most humans to the place of their upbringing allowed thoughts of a return under some conditions, for some duration, to enter the minds of nearly every member of oregon's cubanAmerican community. In the view offered by a more dispassionate evaluation of the real world situation however, most members of the group would agree with Daniele Fajardo, Jr.,: "What we left behind is not there, and if it's there it's not ours."20

There is, perhaps, no clearer statement of the transition undergone by Portland's Cuban-American community. As arrivals with adult memories of life on the island died or moved to warmer climates, the linkages between those who remained in oregon and cuba eroded. Meanwhile, second and third generation offspring demonstrated continuity with the earlier immigrants' notable abilities and adaptive capabilities. By 1990 the process of assimilation was far enough advanced to make anything more than a temporary visit to cuba completely 
out of the question for nearly any member of Portland's CubanAmerican population. It is difficult to imagine that even a fundamental change in the island's political or economic infrastructure would draw more than a small percentage of retired emigres back to Cuba, as even most of these would prefer to remain in proximity to fully Americanized family members.

The rapidity of this assimilation, which also pertained to the national Cuban-American community, outstripped the halting strides made by other Spanish American groups, such as Mexicans and Puerto Ricans. Factors mentioned in discussion of the cuban success story received support from the experiences of Oregon's community. These included the educated and successful background of many arrivals, and the continued emphasis they placed on education; a strong sense of independence and a corresponding drive which led, among other things, to the effective surmounting of the language barrier; and the possession of genetic and cultural similarities to already established United States citizens. The community's loss of much of its Spanish American cultural heritage, while not insignificant, involved a complementary gain for the wider society via the infusion of a dynamic element into the mainstream. This is a graphic illustration of the working of the "long count" in history, all the more valuable to Oregonians for having been played on the local stage. 


\section{REFERENCES CONSULTED}

BOOKS

Alexander, Robert J., editor. Aprismo: The Ideas and Doctrines of Victor Raúl Haya de la Torre. The Kent State University Press. 1973.

Batista, Fulgencio. Cuba Betrayed. Vantage Press. New York, Washington, Hollywood. 1962.

Bernstein, Harry. origins of Inter-American Interest. University of Pennsylvania Press. Philadelphia. 1945.

Bonsal, Philip w. Cuba, Castro, and the United states. University of Pittsburgh Press. 1971.

Boswell, Thomas D. and James R. Curtis. The Cuban-American experience. Culture, Images, and Perspectives. Rowman and Allanheld. Totowa, New Jersey. 1983.

Casuso, Teresa. Cuba and Castro. Random House. New York. 1961.

Chilcote, Ronald H., editor. Cuba, 1953-1978:

bibliographic guide to the literature. 2 Volumes. Kraus International Publications. White Plains, New York. 1986.

Cortes, Carlos E., editor. Cuban Exiles in the United States. Arno Press. New York. 1980.

Cortes, Carlos E., editor. Cuban Refugee Programs. Arno Press. New York. 1980.

Cortes, Carlos E., editor. The Cuban Experience in the United States. Arno Press. New York. 1980.

Cota-Robles Newton, Frank, Esteban L. Olmedo, and Amado M. Padilla. Hispanic Mental Health Research. University of California Press. 1982. Berkeley, Los Angeles, London. 1982

Cuban National Planning Council. Evaluation and identification of policy issues in the cuban community. Miami, Florida. 1980. 
Curtin, Margaretta. Cubanitos in a new land. Florida Mazon Press. Hialeah. 1975.

Didion, Joan. Miami. Simon and Schuster. New York. 1987.

Dinges, John and Saul Landau. Assassination on Embassy Row. Pantheon Books. New York. 1980.

Fagen, Richard R., Richard A. Brody, and Thomas J. O'Leary. Cubans in Exile. Stanford University Press. Stanford. 1968 .

Fagen, Richard R. The transformation of political culture in Cuba. Stanford University Press. Stanford. 1969.

Farber, samuel. Revolution and Reaction in Cuba, 1933-1960. Wesleyan University Press. Middletown, Connecticut. 1976.

Federal Writers' project. Florida: a guide to the Southernmost state. Oxford University Press. New York. 1946.

Feliciano y Díaz. New Immigrants: portraits in passage. "Happy days in Miami." Pilgrim Press. New York. 1981.

Foner, Philip S. A History of Cuba and its relations with the United states. Two Volumes. International Publishers. New York. 1963.

Fox, Geoffrey E. Working-class emigres from cuba. $R$ \& E Associates. Palo Alto. 1979.

Gallagher, Patrick Lee. The Cuban exile. Arno Press. New York. 1980.

Garver, Susan. Coming to North America: from Mexico, Cuba, and Puerto Rico. Delacorte Press. New York. 1981.

Gellman, Irwin F. Roosevelt and Batista. Good Neighbor Diplomacy in Cuba, 1933-1945. University of New Mexico Press. Albuquerque. 1973.

Gernand, Renee. The Cuban-Americans. Chelsea House. New York. 1988 .

González, Esther B. Annotated bibliography on Cubans in the United States, 1960-1976. Gonzalez. Miami. 1977.

Grupo Arieto. Contra Viento y Marea. Siglo Veintiano Editores. Mexico. 1978 . 
Guevara, Che. Reminiscences of the Cuban Revolutionary War. Grove Press, Inc. New York and London. 1968.

Guevara, Che. Guerilla warfare. University of Nebraska Press. Lincoln and London. 1985.

Hernández, Andres R. The Cuban Minority in the U.S. Volume II. Arno Press. New York. 1980.

Hinkle, warren and william w. Turner. The Fish is Red. Harper and Row. New York. 1981.

The Hispanic Almanac. The Hispanic Policy Development Project, Inc. New York. 1984.

Jefferson, Thomas. The Writings of Thomas Jefferson. The Thomas Jefferson Memorial Association. Washington, D.C. 1904 .

Jorge, Antonio. Latin-Anglo American cross cultural influences and the political economy of change. Latin American and Caribbean Center, Florida International University. Tamiami Trail, Miami, Florida. 1982.

Larzelere, Alex. The 1980 Cuban boatlift. National Defense University Press. Fort Lesley J. MCNair. 1988.

Liss, Sheldon B. Roots of Revolution: Radical Thought in Cuba. University of Nebraska Press. Lincoln and London. 1987.

Llanes, José. Cuban Americans: Masters of Survival. Abt Books. Cambridge, Massachusetts. 1982.

Louie de Irizarry, Florita Z. U.S. women of Spanish origin in the employment sector: a selected bibliography. Vance Bibliographies. Monticello, Illinois. 1982.

McCoy, Clyde B. and Gonzalez, Diana H. Cuban immigration and immigrants in Florida and the United states: implications for immigration policy. Bureau of Economic and Business Research, University of Florida. Gainesville, Florida. 1985.

MacCorkle, Lyn. Cubans in the U.S.: A Bibliography. Greenwood Press. Westport, Connecticut. 1984 .

McNally, Michael J. Catholicism in South Florida, 1868-1968. University of Florida Press. Gainesville. 1982. 
Marti, José. Our America. Edited, with an Introduction and Notes, by Philip S. Foner. Monthly Review Press. New York and London.

Masud-Piloto, Felix Roberto. With open arms: Cuban migration to the U.S. Rowman and Littlefield. Totowa, New Jersey. 1988.

Martinson, Tom L. and Gary S. Elbow, editors. Geographic Research on Latin America: Benchmark 1980. Proceedings of the Conference of Latin Americanist Geographers. Conference of Latin Americanist Geographers. 1981.

Matthews, Herbert L. Revolution in Cuba. Charles Scribner's Sons. New York. 1975.

Miyares, Marcelino. Models of political participation of Hispanic-Americans. Arno Press. New York. 1980.

Moore, John Bassett, editor. The Works of James Buchanon, comprising his speeches, state papers, and private correspondence. Antiquarian Press, Ltd. New York. 1960

Morley, Morris H. Imperial state and Revolution: The United States and Cuba, 1952-1986. Cambridge University Press. Cambridge. 1987.

Múniz, José Rivero. The Ybor City Story. Translated by Eustasio Fernandez and Henry Beltran. Tampa.

Nevins, Allan, editor. The Diary of a President. 1845-1849. Capricorn Books. New York. 1968.

Nixon, Richard M. Six Crises. Doubleday and Company, Inc. Garden City, New York. 1962.

Pedraza-Bailey, silvia. Political and economic migrants in America: Cubans and Mexicans. University of Texas Press. Austin. 1985.

Pérez, Louis A., Jr. Cuba Between Empires. Oxford University Press. New York. Oxford. 1988.

Pérez, Louis A., Jr. Cuba. Between Reform and Revolution. Oxford University Press. New York, Oxford. 1988.

Philipson, Lorrin and Rafael Llerena. Freedom Flight. Cuban refugees talk about life under castro and how they fled his regime. Random House. New York. 1980. 
Portes, Alejandro and Robert L. Bach. Latin Journey: Cuban and Mexican Immigrants in the United States. University of California Press. Berkeley, Los Angeles, London. 1985 .

Poyo, Gerald E. "With All, and for the Good of All," The Emergence of Popular Nationalism in the Cuban Communities of the United States, 1848-1898. Duke University Press. Durham and London. 1989.

Prohias, Rafael J. and Lourdes Casal. The Cuban minority in the U.S. Volume I. Arno Press. New York. 1980.

Richmond, Marie LaLiberte. Immigrant Adaptation and Family Structure among Cubans in Miami, Florida. Arno Press. New York. 1980.

Rogg, Eleanor Meyer. The assimilation of Cuban exiles. Aberdeen Press. New York. 1974.

Rogg, Eleanor Meyer. Adaptation and adjustment of Cubans, West New York, New Jersey. Hispanic Research Center, Fordham University. Bronx, New York. 1980.

Ropka, Gerald William. The evolving residential pattern of the Mexican, Puerto Rican, and Cuban population in the city of Chicago. Arno Press. New York. 1980.

Rouse, Irving. Migrations in prehistory. Yale University Press. New Haven and London. 1986.

Rubens, Horatio S. Liberty: The story of Cuba. Ams Press. New York. 1932 .

Simon, Rita J. Immigration and American public policy. Sage Publications. Beverly Hills, California. 1986.

Smith, Earl E.T. The Fourth Floor. An Account of the Castro Communist revolution. Random House. New York. 1962 .

Smith, Robert F. The United States and Cuba. Business and Diplomacy, 1917-1960. Bookman Associates. New York. 1960.

Spero, Abby. In America and in need: immigrant, refugee, and entrant women. American Association of Community and Junior Colleges. Washington. 1985.

Stewart, T. D. The People of America. Charles Scribner's Sons. New York. 1973. 
Suárez, Andres. Cuba: Castrosim and Communism, 1959-1966. The M.I.T. Press. Cambridge and London. 1967.

Tebeau, Charlton W. A History of Florida. University of Miami Press. Coral Gables, Florida. 1971.

Thomas, Hugh. Cuba: The Pursuit of Freedom. Harper and Row. New York. 1971.

Thompson, Raymond H., editor. Migrations in New World Culture History. University of Arizona Press. Tucson. 1958.

United states Department of state. Foreign Relations of the United States. Diplomatic Papers. United States Government Printing Office. Washington, D.C.

Varona, Experanza Bravo de. Cuban exile periodicals at the University of Miami Library. Secretariat, Seminar on the acquisition of Latin American library materials, Memorial library, University of wisconsin--Madison. Madison. 1987.

Welch, Richard E., Jr. Response to Revolution. The University of North Carolina Press. Chapel Hill and London. 1985.

Willey, Gordon R. Archeology of the Florida Gulf Coast. AMS Press Inc. Cambridge, Massachusetts. 1973.

Wisan, Joseph E. The Cuban Crisis as Reflected in the New York Press (1895-1898). Octagon Books, Inc. New York. 1965.

Wissler, Clark. The American Indian: an introduction to the anthropology of the new world. Peter Smith. Gloucester, Mass. 1957.

$$
\text { NON-BOOK SOURCES }
$$

\section{Pre-Revolution}

Americas. Volume 26 (February 1974), pp 13-19. Edward D. Fitchen. "1300 cuban teachers in Boston."

Volume 34 (July/August 1982), pp 41-45. "Immigrants in society."

Florida Historical Quarterly. April, 1977, pp 407-422. Gerald E. Poyo. "Cuban Revolutionaries and Monroe Country Reconstruction Politics, 1868-1876." 
January, 1979, pp 289-305. Gerald E. Poyo. "Key West and the Cuban Ten Years War."

The Hispanic American Historical Review. Volume 19 (1939), pp 268-305. George W. Auxier. "The Propaganda Activities of the Cuban Junta in Precipitating the Spanish-American War, 1895-1898."

Volume 36 (1956), pp 38-49. T. C. Appel. "The Unionization of Florida Cigarmakers and the coming of the War with Spain."

Michigan History. Volume 48 (1977), pp 35-46. Raymond A. Detter. "The Cuban Junta and Michigan: 1895-1898."

Preece, Carol Ann. Insurgent Guests: The Cuban Revolutionary Party and its Activities in the United States, 1892-1898. Georgetown University. 1975.

True, Marshall MacDonald. Revolutionaries in Exile: The Cuban Revolutionary Party, 1891-1898. University of Virginia. 1965.

Revolution to Mariel

Aging. Volume 193 (November-December 1970), p 17. "Learned Cuban, 85, continues studies in Miami, seeking job."

America. Volume 104 (18 February 1961), pp 664-665. Charles Shreiner. "Gloom over Miami."

Volume 104 (18 March 1961), p 777. "Plight of Cuban refugees."

Volume 114 ( 1 January 1966), p 3. "Cuban exodus resumes."

Volume 114 (26 February 1966), pp 286-289. Bryan 0. Walsh. "Cubans in Miami."

American Demographics. Volume 1 (January 1979), pp 40-41. Kathleen S. Platt. "Hispanic Americans."

American Education. Volume 1 (March 1965), pp 29-33. Antonio A. Micocci. "New Life for Cuban Exiles."

American Journal of Psychiatry. Volume 133 (April 1976), pp 395-399. Ruben D. Rumbaut and Ruben G. Rumbaut. "The family in exile: Cuban expatriates in the United states." 
Americas. Volume 31 (February 1979), pp 13-15. Guillermo de zendegui. "Celebrating a heritage."

The Atlantic Monthly. Volume 242 (November 1978), pp 16-17, 20-22. Russell Warren Howe. "Cuba: Private Gutierrez goes to war."

Business Week. 31 December 1960, p 80. "Resettling Cuban refugees."

13 October 1962, pp 120, 124. "Cubans raise a storm."

3 November 1962, pp 92-94. "To Miami, refugees spell prosperity."

16 October 1965, pp 30-31. "Miami fears impact of another Cuban wave."

12 March 1966, p 69. "Cuba's new refugees get jobs fast."

11 January 1969, p 84. "Cuban refugees write a success story."

21 June 1969, p 41. "Cubans take off on SBA test run." 1 May 1971, pp 88-89. "How the immigrants made it in Miami."

Christian Century. Volume 78 (7 June 1961), p 703. Russell Stevenson. "Refugees still coming."

Volume 78 (11 October 1961), pp 1209-1213. Everett C. Parker. "Miami's real-life drama."

Volume 78 (18 October 1961), pp 1241-1242. Everett C. Parker. "Miami: test for the churches."

Volume 78 (22 November 1961), pp 1390-1391. Everett C. Parker. "Help for Cuban refugees."

Volume 79 (4 April 1962), pp 417-418. "Refugee Cuban children need homes."

Volume 79 (19 December 1962), p 1552. "Cuban refugee problem increases."

Volume 80 (29 May 1963), p 702. "Protestants to aid Catholic refugees."

Volume 81 (22 January 1964), pp 100-101. "U.S. changes policy on cuban refugees." 
Volume 82 (27 October 1965), p 1310. "Another exodus."

Commentary. Volume 56 (July 1973), pp 50-60. Joan Colebrook. "Key West with Cubans."

Commonweal. Volume 83 (19 November 1965), pp 210-211. C.K. Yearley. "Cubans in Miami."

Volume 89 (7 February 1969), p 574. "News and views:"

Cuban Studies. Volume 7 (January 1977), pp 1-32. Alejandro Portes, Juan M. Clark, Robert L. Bach. "The New Wave: A Statistical Profile of Cuban Exiles to the United States."

Department of State Bulletin. Volume 43 (12 December 1960), pp 888-889. "President asks Mr. Voorhees to study Cuban refugee problem."

Volume 44 (9 January 1961), pp 45-48. "President's representative on Cuban refugee problem submits report."

Volume 44 (13 February 1961), pp 219-225. "Mr. Voorhees submits final report on Cuban refugee problem."

Volume 44 (20 February 1961), pp 256-257. "Mr. Voorhees resigns; Mr Ribicoff to coordinate Cuban refugee program; letters"

Volume 44 (27 February 1961), pp 309-310. "President outlines measures for aiding Cuban refugees."

Volume 44 (3 April 1961), pp 490-492. "U.S. to assist refugee cuban scholars; exchange of letters between President Kennedy and Abraham Ribicoff."

Volume 45 ( 7 August 1961), p 238. "Free transportation to U.S. offered to Cubans with visas or waivers."

Volume 48 (24 June 1963), pp 983-990. "U.S. outlines policy toward Cuban refugees; statement."

Volume 53 (25 October 1965), pp 661-663. "President signs immigration bill; offers asylum to Cubans."

Volume 53 (25 October 1965), pp 663-664. "OAS informed of U.S. move to help Cuban refugees."

Volume 53 (29 November 1965), pp 850-853. "Procedures established for movement of Cuban refugees to United states." 
Volume 54 (2 May 1966), pp 707-713. "Review of movement of Cuban refugees and hemisphere policy towards Cuba."

Volume 54 (27 June 1966), p 1005. "New procedures to admit Cuban refugees from third countries."

Volume 55 (5 september 1966), pp 348-349. Statement by undersecretary George Ball. "Department supports adjustment of status of Cuban refugees."

Volume 55 (26 December 1966), pp 966-967. "Cuban refugee airlift completes first year of operation."

Volume 55 (26 December 1966), p 967. "Permanent residence application fees for Cuban refugees waived."

Ebony. Volume 18 (June 1963), pp 96-104. Allan Morrison. "Miami's Cuban refugee crisis."

Esquire. Volume 81 (February 1974), pp 90-93, 170-172. Tad szulc. "Cuba on our mind."

Fair Play for Cuba Committee. Cuban Counter-revolutionaries in the United States: Who Are They? New York. 1962.

Fortune. Volume 74 (October 1966), pp 144-149. Tom Alexander. "Those amazing Cuban emigres."

Industrial and Labor Relations Review. Volume 31 (April 1978), pp 336-346. James D. Gwartney and James E. Long. "The relative earnings of blacks and other minorities."

Inquiry. Volume 2 (5 March 1979), pp 15-21. Jonathan Marshall. "A new Watergate revelation: the white House Death squad."

International Legal Materials. November 1965, pp 1118-1127. "Cuba-U.S. agreement on refugees."

International Migration. Volume 16, Numbers $3 \& 4$ (1978), pp 160-173. Raúl Moncarz Percal. "The golden cage--Cubans in Miami."

International Migration Review. Spring 1967, pp 23-33. William S. Bernard. "The integration of immigrants in the United States."

Spring 1967, pp 46-57. John F. Thomas. "Cuban refugees in the United States." 
Journal of Latin American Studies. Volume 5 (November 1973), pp 271-278. Lynn Darrell Bender. "The Cuban Exiles:

An Analytical study."

Latin American Research Review. Volume 11 (1976), pp 103-124. Benigno E. Aguirre. "Differential Migration of Cuban Social Races."

Life. Volume 49 (31 October 1960), pp 16-21. "Refugees, a reprisal and an empty harbor; Training for counterrevolt."

Volume 50 (14 April 1961), pp 30-33. "Uneasy life in alien land."

Volume 53 (16 November 1962), pp 55-58. Andrew st. George. "Hit and run to Cuba with Alpha 66."

Volume 54 (12 April 1963), pp 18-25. Andrew St. George. "Vamos! The buccaneers attack the Soviet prey."

Volume 54 (3 May 1963), p 4. "We should help the Cuban exiles find a leader."

Volume 57 (28 August 1964), pp 22-33. Juana Castro. "My brother is a tyrant and he must go."

Volume 59 (5 November 1965), pp 38-39. "Fidel's pizzeria diplomacy paves the way for an exodus; Swiss Ambassador acts as United States mediator."

Volume 71 (10 December 1971), pp 36-41. "Making it in Miami, Cuban-style."

Look. Volume 26 (24 April 1962), pp 25-31. "Romona crashes Cuba's iron curtain."

Volume 28 (29 December 1964), pp 60-65. "Girl spy against Castro."

Volume 29 (1 June 1965), pp 83-87. "Tony Oliva: Twins' lonely star."

Macleans. Volume 91 (24 July 1978), pp 22-27. William Lowther. "Enemy grows older; and if Cuba's exiles are right, more vulnerable."

Volume 93 (25 February 1980), pp 7-8. William Lowther. "Arguing with bullets on the cuba front."

The Nation. Volume 192 (7 January 1961), p 1. "Asylum or staging ground?" 
Volume 192 (21 January 1961), pp 41-42. "Nothing to fear? Plotting against Castro regime."

Volume 196 (13 April 1963), p 297. "Practice makes perfect."

Volume 197 (12 October 1963), p 209. "New look at Cuba." Volume 198 (22 June 1964), pp 613-614. "Visible CIA."

Volume 200 (25 January 1965), pp 76-79. Al Burt. "Cuban exiles: the mirage of Havana."

Volume 201 (18 October 1965), pp 251-252. José Yglesias. "Cuba's bestseller: A gusano returns."

Volume 212 (8 March 1971), pp 299-302. Al Burt. "Miami: the Cuban flavor."

Volume 212 (12 April 1971, p 450. Reply to "Miami: the Cuban flavor."

Volume 214 (20 March 1972), p 356. "Let them in; visas for Cuban film directors rejected."

Volume 217 ( 3 September 1973), p 164. "Moment of truth." Volume 224 (19 March 1977), pp 326-331. "Miami, haven for terror."

Volume 224 (26 March 1977), pp 358-360. Saul Landau and Ralph stavins. "The Letellier/Moffit murder: This is how it was done."

National Geographic. July 1973, pp 68-95. Edward J. Linehan. "Cuba's exiles bring new life to Miami."

National Journal. Volume 11 (7 April 1979), pp 548-555. Neal R. Pierce and Jerry Hagstrom. "The Hispanic communitya growing force to be reckoned with."

National Review. Volume 21 (28 January 1969), p 60. "88 got away."

Nation's Business. Volume 60 (March 1972), pp 78-82. "Success with a Spanish accent."

NEA Journal. Volume 51 (December 1962), pp 38-39. "Teachers from Cuba, a cultural import."

The New Leader. 13 May 1963, pp 3-6. Antonio de la Carrera. "Cuba: What Now?" 
New Republic. Volume 144 (19 June 1961), p 5. "Stranded on the beach."

Volume 147 (10 November 1962), p 9. "What Next Cuba--An Exile's View."

Volume 148 (13 April 1963), p 6. "Blunted arrow's head."

New Times. Volume 7 (29 october 1976), pp 36-37, 40-45. Dick Russell. "Little Havana's reign of terror."

New York. Volume 12 (10 September 1979), pp 42-49. Jeff Stein. "Army in exile; Cuban nationalist movement in Union City, New Jersey."

The New York Times. 12 December 1972, p 19. "A study finds half of cuban refugees are outside Florida."

The New York Times Magazine. 13 March 1960, pp 25, 84-87. William C. Baggs. "Other Miami, city of intrigue."

11 June 1961, pp 8-9. "Still they flee from Cuba."

30 September 1962, pp 21-22, 84-87. Milton Bracker. "Cuba's refugees live in hope--and despair."

21 April 1963, pp 7+. Milton Bracker "Bitter, frustrated, divided: Cuba's refugees."

5 July 1964, pp 9+. Tal szalc. "Guerra--still the word in Miami."

7 November 1965, pp 30-31, 129-130, 132. Gertrude Samuels. "Why Castro exports Cubans."

29 September 1974, pp 28-29,104-110, 114, 123. Susan Jacoby. "Miami si, Cuba no."

The New Yorker. Volume 39 (6 July 1963), pp 22-23. "Man in Havana; J. B. Donovan."

Volume 47 (16 october 1971), pp 107-145. José Yglesias. "Romeo and Julieta: growing up among Cuban relatives in Tampa, Florida."

Volume 51 (30 June 1975), pp 94-96. Calvin Trillin. "U.S. Journal: Union City, N.J."

Newsweek. Volume 56 (31 October 1960), p 51. "Blow for blow."

Volume 57 (27 February 1961), p 58. "Refugee eggheads." 
Volume 57 (3 April 1961), p 51. "Exiles, Inc."

Volume 58 (31 July 1961), p 47. "Operation airlift."

Volume 58 (28 August 1961), pp 23-27. "Agonizing wait, then the hard realities of a refugee's life; Defection at sea."

Volume 58 (6 November 1961), p 57. "Mournful Mariano." Volume 58 (4 December 1961), p 59. "They're OK."

Volume 59 (26 February 1962), p 58. "Refugee resettlement."

Volume 60 (29 October 1962), p 44. "Every exile is an island."

Volume 62 (19 August 1963), p 75. "Iowa, si!"

Volume 66 (18 October 1965), pp 48-49. "Another Dunkirk?"

Volume 66 (25 October 1965), pp 33-34. "Compound at Camarioca."

Volume 66 (1 November 1965), p 54. "Exodus."

Volume 66 (8 November 1965), p 33. "Fly now."

Volume 66 (15 November 1965), p 70. "Fidel's challenge." Volume 67 ( 6 June 1966), p 55. "The door stays open." Volume 73 (20 January 1969), pp 44-45. "Cuba: who's fooling whom?"

Volume 74 ( 1 September 1969), p 59. "Havana, Florida." Volume 85 (17 March 1975), pp 29-32. "Backlash in Miami."

Volume 86 (1 September 1975), pp 54-55. "Miami's angry Cubans."

Volume 87 (14 June 1976), p 35. "The Cuban list."

Volume 90 (12 December 1977), p 20. "Brigade 2506."

Volume 95 ( 11 February 1980), pp 36-41. "Miami: Latin crossroads." 
The Price Waterhouse Review. Volume 22, Number 1 (1977), pp 6-17. "The Latinization of Miami."

PTA Magazine. Volume 58 (September 1963), pp 31-32. Claiborne Marburgh. "Operation simpatico."

Reader's Digest. Volume 78 (May 1961), pp 112-116. Joseph P. Blank. "Castro betrayed our country."

Volume 81 (December 1962), pp 68-72. James Nathan Miller. "Opportunity or disaster; the challenge of Cuba's exiles."

Volume 84 (May 1964), pp 159-162. Joseph P. Blank. "Incredible escape."

Volume 86 (April 1965), pp 131-132. Henry J. Taylor. "Carnage off Key West; escaping refugees killed by Castro's patrols."

Volume 90 (February 1967), pp 19-20. James Nathan Miller. "Bienvenidos! to Cuba's refugees."

Volume 95 (July 1969), pp 98-103. William Schulz. "Truck that fled cuba."

Volume 100 (May 1972), pp 104-109. Joseph P Blank. "Escape from Cuba."

Redbook. Volume 120 (March 1963), pp 46+. Bernard Asbell. "A Cuban doctor's decision."

Review of Public Data Use. Volume 4 (May 1976), pp 12-23. Mary M. Kritz and Douglas T. Gurak. "Ethnicity and fertility in the U.S.: an analysis of 1970 public data use."

Saturday Evening Post. Volume 234 (8 April 1961), pp 19-21, 77-80. Harold H. Martin. "Angry exiles in Florida."

Volume 235 (16 June 1962), p 74. "Our refugees from Castroland."

Volume 236 (8 June 1963), pp 28-33. Harold H. Martin. "Help us fight! cry the angry exiles."

School and Society. Volume 94 (24 December 1966), p 476. "Loans to Cuban refugee students."

School Life. Volume 44 (November 1961), p 13. "Education of Cuban refugees." 
Senior Scholastic. Volume 82 ( 1 May 1963), pp 8-9, 26. "Miami si, Castro no."

Volume 87 (4 November 1965), p 20. "Free to leave."

Volume 102 (30 April 1973), pp 16-17. "New immigrants profile of Spanish influences."

Seventeen. Volume 22 (April 1963), p 28. Annabelle Armstrong. "I believe."

Social Problems. Volume 11 (Spring 1964), pp 389-401. Richard R. Fagen and Richard Brody. "Cubans in Exile:

A Demographic Analysis."

Social Science ouarterly. Volume 59 (September 1978), pp 295310. Douglas T. Gurak. "Sources of ethnic fertility differences: an examination of five minority groups."

Volume 60 (June 1979), pp 35-50. Myra Max Gerree. "Employment Without Liberation--Cuban Women in the United states."

Social Security Bulletin. March 1962, pp 3-8. William L. Mitchell. "The Cuban Refugee Program."

The Social Service Review. Volume 36 (December 1962), pp 377384. Katherine Brownell oettinger. "Services to Unaccompanied Cuban Refugee children in the United states."

Sociology of Education. Volume 51 (October 1978), pp 241-260. Alejandro Portes, Samuel A. McLeod, Jr., and Robert N. Parker. "Immigrant aspirations."

Sports Illustrated. Volume 17 (27 August 1962), pp 8-11. Rex Lardner. "Bad blood in the tropics."

Time. Volume 76 (12 December 1960), pp 32-34. "They would be free."

Volume 77 ( 3 March 1961), pp 34-37. "The man on $t h e$ raft."

Volume 77 (31 March 1961), p 24. "Getting ready."

Volume 77 (19 May 1961), p 34. "Outward bound."

Volume 78 (18 August 1961), p 33. "New exodus."

Volume 78 (15 September 1961), pp 38-43. "Hard new life." 
Volume 78 (22 December 1961), p 14. "At war in Miami." Volume 79 (13 April 1962), pp 79-80. "Doctors in exile." Volume 80 (24 August 1962), p 26. "Running the other way."

Volume 81 (26 April 1963), pp 21-22. "That month."

Volume 82 (27 September 1963), p 24 . "Safety in the stars."

Volume 84 (11 September 1964), p 28. "Pulling the tail." Volume 86 (15 October 1965), p 51. "Farewell, dear hearts."

Volume 86 (22 October 1965), pp 48-53. "Gusanos' paradise."

Volume 86 (29 October 1965), p 38. "More refugees, more blackmail."

Volume 86 ( 5 November 1965), p 56. "And now by air."

Volume 86 (12 November 1965), pp 36-37. "No place like it."

Volume 86 (10 December 1965), p 46. "Exodus by air." Volume 86 (31 December 1965), p 24. "Full seats \& a cruel promise."

Volume 87 (1 April 1966), pp 34-35. "The freedom flood." Volume 87 (8 April 1966), p 36. "Do-it-yourself airlift."

Volume 88 (9 December 1966), p 44. "Airlift anniversary."

Volume 89 (6 January 1967), p 31. "A new shuttle." Volume 93 (17 January 1969), p 31. "Freedom riders."

Volume 98 (13 September 1971), p 34. "End of the freedom flights."

Volume 101 (11 June 1973), p 104. "Cuban doctors' dilemma." 
Volume 104 (24 October 1974), p 24. "La Saguesera: Miami's little Havana."

Volume 112 (16 October 1978), pp 48-52. "It's your turn in the sun."

United states congress. House. Judiciary Committee, subcommittee \#1. Study of Population and Immigration Problems. Inquiry into the selection, security Screenings, Admissions, Emergency Care, and Resettlement of Cuban Refugees in the U.S. Special Series 14. United States Government Printing office, 1963.

United states Congress. House, select Committee on Aging. Needs of the Hispanic elderly. Hearing, 95th Congress, 2nd Session. United States Government Printing office, 1978 .

United States Congress. Senate, Judiciary Committee. Cuban Refugee Problems. Hearings. 1962,304 pp; 1963,399 pp; 1964,304 pp.

United States Congress. Senate, Judiciary Committee. Resettlement of Cuban Refugees. 88th Congress, 1st Session, 6 December 1963.

United State Congress. Senate, Judiciary Committee, Subcommittee to Investigate the Administration of the Internal Security Act and other Internal security Laws. "Terroristic activity; terrorism in the Miami area." Hearings, 94th Congress, 2nd Session, Part 8. 6 May 1976, pp 607-662. United state Government Printing Office, 1976 .

United States Department of Health, Education, and Welfare. Welfare in Review. Volume 1, no. 3, September, 1963. John F. Thomas "Cuban Refugee Program."

United States Department of Health, Education, and Welfare. Social and Rehabilitation Service. Children's Bureau. Cuba's Children in Exile. The story of the Unaccompanied Cuban Refugee Children's Program. 1967.

United States Department of Health, Education, and Welfare. Social and Rehabilitation Service. Cuban Refugee Program. The Cuban Refugee Program. 1970.

United States Department of Health, Education, and Welfare. Social and Rehabilitation Service. Comptroller General's report: Analysis of Federal Expenditures to Aid Cuban Refugees. 1972 . 
United states Department of Health, Education, and Welfare. Social and Rehabilitation service. Cuban Refugee Program. Professional Manpower: a new way to meet the need. 1974 .

United States Department of State. Inter-American Series. Washington, D.C.

United States Department of State. Movement of Cuban Refugees to the United States. Treaties and other International Acts Series 6063. 1966.

United States General Accounting office. Comptroller General of the United States. Report to the Congress of the United States. Weaknesses in Negotiation and Administration of contracts for Resettlement of cuban Refugees. March 1965.

U.S. News and World Report. Volume 45 (22 August 1958), pp 69-71. "How plotters use U.S. to hatch revolts."

Volume 49 (5 December 1960), pp 59-64. "Anti-Castro uprising? here's a headquarters report."

Volume 50 (23 January 1961), pp 79-81 "Anti-Castro war already is already underway."

Volume 50 (30 January 1961), pp 64-65. "As Castro's foes get ready to strike."

Volume 54 (29 April 1963), pp 33-36. "Another Cuban fiasco."

Volume 54 (29 April 1963), pp 65-67, 100-102. "A refugee leader blames U.S. for broken promise."

Volume 56 (11 May 1964), p 39. "Coming: new effort to topple Castro?"

Volume 56 ( 8 June 1964), p 21. "New command for antiCastro Cubans."

Volume 57 ( 3 August 1964), p 8. "When Cuban exiles broke loose in Washington."

Volume 59 (11 October 1965), p 15. "How many more Cubans coming to U.S.?"

Volume 59 (25 October 1965), pp 55-56. "New flight from Castro--new headache for U.S." 
Volume 59 ( 8 November 1965), pp 49-51. "Why Castro allows Cubans to flee--the dictator's worries."

Volume 59 (22 November 1965), pp 16-17. "Freedom flight plan: 200,000 to flee Cuba?"

Volume 62 (20 March 1967), pp 104-106. "A Cuban success story--in the U.S."

Volume 66 (20 January 1969), p 5. "Drama of flight from Castro terror."

Volume 67 (28 July 1969), p 6. "Whatever happened to...the cuban airlifts?"

Volume 67 (20 October 1969), p 17. "How a Cuban MIG sneaked into U.S."

Volume 68 (9 March 1970), p 16. "Whatever happened to the Bay of Pigs veterans?"

Volume 70 (31 May 1971), pp 74-77. "Flight from Cuba: Castro's loss is U.S. gain."

Volume 71 (13 September 1971), p 91. "Why Castro is halting the airlift."

Volume 78 (26 May 1975), p 31. "Cubans--exile militants-a danger to the U.S.?"

Volume 80 (5 April 1976), p 29. "Miami's Cubans, getting a taste for politics."

Volume 81 ( 6 December 1976), pp 29-32. "Cuban extremists in U.S. a growing terror threat."

Volume 81 ( 6 December 1976), p 30. "Exiles vs. Castro-a relentless pursuit."

Volume 86 (19 February 1979), pp 66-69. "Miami: new Hispanic power base in U.S."

Volume 86 (7 May 1979), p 13. "When exiles pay a visit to Cuba."

Washington Post. 7 November 1976, pp C1, C3. George Crile III. "Our heritage--the exile cuban terrorists."

Wilson Library Bulletin. Volume 36 (June 1962), pp 825-828. Helga H. Eason. "More than money." 
Volume 44 (March 1970), pp 722-723. Americans with a Hispanic tradition."

Volume 44 (March 1970), pp 760-763. Helga H. Eason. "Miami, Florida."

\section{Post-Mariel}

Advertizing Age. Volume 56 (21 March 1985), p 30. "Cuban pride in heritage steer market."

America. Volume 142 (26 April 1980), p 351. "Seeking asylum in Havana."

Volume 142 (17 May 1980), pp 420-421. Bryan O. Walsch. "Boat people of South Florida."

Volume 142 (31 May 1980), pp 452-453. "The Cuban Exodus."

Volume 156 (18 April 1987), pp 315-316. Glen Galbaugh. "Excludable from justice."

Americas. Volume 40 (March/April 1988), pp 2-7. Omar Amador. "Ybor City making the past its future."

American Demographics. Volume 5 (March 1983), pp 14-25. Cheryl Russell. "The news about Hispanics."

Volume 8 (June 1986), pp 18, 66. "One million Cubans."

Volume 9 (September 1987), p 22. "Hispanic hype."

Volume 10 (January 1988), pp 136-142. "Hispanics in the eighties."

The American Journal of Psychiatry. Volume 142 (January 1985), pp 86-89. Peter A. Boxer and James T. Garvey. "Psychiatric diagnoses of Cuban refugees in the United states."

The American Journal of Sociology. Volume 86 (September 1980), pp 295-319. Kenneth L. Wilson and Alejandro Portes. "Immigrant enclaves: an analysis of the labor marked experiences of Cubans in Miami."

Volume 88 (July 1982), pp 135-160. Kenneth L. Wilson and w. Allen Martin. "Ethnic enclaves: a comparison of the Cuban and Black economies in Miami." 
American Lawyer. Volume 10 (January-February 1988), pp 136142. Ann Woolner. "He tried to give justice to cubans in America."

American Opinion. Volume 24 (June 1981), pp 13-18, 87-96. John Rees. "How unregistered agents are manipulating U.S. policy."

Volume 26 (December 1983), pp 15-24+. Steven V. Cole. "What the U.S. can do to rescue Cuba next."

American Sociological Review. Volume 52 (December 1987), pp 745-767. Jimy M. Sanders and Victor Nee. "Limits of ethnic solidarity in the enclave economy."

Annals of the American Academy of Political and Social Science. Volume 454 (March 1981), pp 98-110. Joseph P. Fitzpatrick and Lourdes Travieso Parker. "HispanicAmericans in the eastern United States."

Volume 454 (March 1981), pp 164-177. Fred G. Burke. "Bilingualism/biculturalism in American education: an adventure in wonderland."

Volume 487 (September 1986), pp 126-212. Lisandro Pérez. "Cubans in the United States."

Atlanta. Volume 25 (June 1985), pp 41+. O. J. Keller. "The Joint Could Blow."

The Atlantic Monthly. Volume 247 (February 1981), pp 72-81. James Conaway. "Unwanted immigrants: Cuban prisoners in America."

Aviation Week and Space Technology. Volume 112 (2 June 1980), pp 27-28. James ott. "Carriers bid for Cuba exile charter."

Volume 113 (25 August 1980), p 21. "Security blunts hijackings; Cuba spurns negotiations."

Business Week. 25 August 1980, pp 86-88. "New wave of Cubans is swamping Miami."

16 November 1981, p 65. "A new wave of Cubans may be on the horizon."

4 February 1985, pp 86-87. Carla Anne Robbins. "Southern Florida's melting pot is about to boil." 
Caribbean Review. Volume 11 (Winter 1982), pp 22+. Robert L. Bach. "The New Cuban Exodus: Political and Economic Motivations."

Volume 13 (Fall 1984), pp 4+. Mario A. Rivero. "Refugee Chess: policy by default."

Change. Volume 13 (July/August 1981), p 29. "A new community role."

Chicago. Volume 29 (September 1980), pp 152-155. Alfredo S. Lanier. "Give me your tired, your poor...the cubans came, but..."

Christian Century. Volume 98 (15-22 July 1981), pp 724-725. Judith L. Woodward. "Forgotten, but not gone yet."

Christian Science Monitor. 5 May (pp 1, 36), 6 May (pp 3, 6), 7 May (pp 3-4) 1987. Marshall Ingwerson. Three part series on Miami.

Christianity Today. Volume 24 ( 6 June 1980), p 48. Adon Taft. "Churches help absorb new wave of refugees."

Columbia Journalism Review. Volume 22 (January-February 1984), pp 9-11. Nery Ynclan. "Thunder on the right in Miami."

Volume 23 (September-october 1984), pp 48-51. John Rothchild. "The Cuban connection and the Gringo press."

Commonweal. Volume 108 (3 July 1981), pp 390-391. J.S. Fuerst. "Images of emigres: the U.S. is never far away."

Volume 114 ( 9 October 1987), pp 552-553. Karen Sue Smith. "Imprisoned in limbo: limits of largess."

Congressional Quarterly. Volume 38 (24 May 1980), p 1414. "Cuban refugee policy."

Volume 38 (31 May 1980), pp 1496-1503. "Cuban refugee crisis may prompt introduction of special legislation."

Volume 44 (5 July 1986), pp 1537-1541. "After years on the sidelines, Cubans finally enter politics."

Volume 47 (2 September 1989), p 2266. "Cuban-Americans' Ethnic Unity Delivers Open 18th to GOP."

Corrections Magazine. Volume 6 (December 1980), pp 42-47. "Prisoners of circumstance: the Cuban problem." 
Volume 8 (April 1982), pp 35-40. Philip B. Taft, Jr. "The Cuban crisis in Miami's jails."

Council for inter-American Security. Clark, Juan M., José I. Lasaga, Rose S. Reque. The 1980 Mariel Exodus: An Assessment and Prospects. 1981.

Counterspy. Volume 8 (March-May 1984), pp 26-30, 59. "Terrorism in Miami: suppressing free speech."

Cuban National Planning Council. Boswell, Thomas D. and Manuel Rivero. First Revised Bibliography Covering Mariel Entrants in the United States. Miami, Florida. 11 May 1984 .

Cuban Studies. Volumes 11, \#2 and 12, \#1 (July 1981-January 1982). "The Cuban exodus: A symposium."

Volume 15, \#2 (Summer 1985), pp 452-459. Robert L. Bach. "Socialist Construction and Cuban Emigration: Exploration into Mariel."

Department of state Bulletin. Volume 80 (July 1980), pp 8081. "Exodus from Cuba."

Volume 80 (August 1980), pp 73-74, 79-82. Victor H. Palmieri. "Cuban refugees."

Volume 81 (October 1981), pp 78-79. Thomas O. Enders. "Cuban and Haitian Migration."

Volume 83 (July 1983), pp 28-30. "President addresses Cuban American community."

Volume 83 (August 1983), pp 86-87. "Return of certain Mariel Cubans."

Volume 85 (February 1985), pp 44-46. "U.S.-Cuba resume normal migration."

Volume 86 (November 1986), p 87. "Arrival of Cuban political prisoners."

Volume 88 (May 1988), pp 77-81. Kenneth N. Skoug, Jr. "The U.S.-Cuba migration agreement resolving Mariel."

Dissent. Fall 1987, p 536. Xavier F. Totti. "The making of a Latino ethnic identity."

The Economist. Volume 305 (28 November 1987), pp 23-24. "When prison is sweeter than home." 
Volume 305 (5 December 1987), p 36. "Back into limbo."

Education. Volume 102 (Winter 1981), pp 106-112. "The spanish-speaking of Chicago health education issues."

Engage/Social Action. Volume 11 (December 1983), pp 11t. Yolanda Rivas. "I am Cuban, I am Hispanic, I am woman."

Esquire. Volume 99 (May 1983), pp 47-56. Thomas B. Morgan. "The Latinization of America."

F.A.C.E.--Facts About Cuban Exiles. 1983. Alberto de Lama. "Tercer aniversario/Puente Mariel--Key West." With an essay by Juan M. Clark. Miami. 1983.

Film Comment. Volume 21 (May-June 1985), p 46. Enrique Fernández. "Miami's autores."

Focus. Volume 35 (April 1985), pp 2-9. Thomas D. Boswell and Manuel Rivero. "Cubans in America: a minority group comes of age."

Volume 35 (April 1985), p 8. "The Mariel Exodus."

Geo. Volume 2 (August 1980), p 31. Marlise Simons. "Let them go."

Harpers. Volume 264 (January 1982), pp 29-39. John Rothchild. "The informant."

The Heritage Foundation. Sylvia Castellanos. The Cuban Refugee Problem in Perspective, 1959-1980. Washington D.C. 18 July 1980 .

Industrial and Labor Relations Review. Volume 35 (April 1982), pp 343-353. George J. Borjas. "The earnings of male Hispanic immigrants in the United States."

International Migration. Volume 25 (September 1987), pp 267282. A. Jorge and R. Moncarz. "The golden cage--Cubans in Miami."

International Migration Review. Volume 14 (Fall 1980), pp 315-341. Alejandro Portes and Robert L. Bach. "Immigrant earnings: Cuban and Mexican immigrants in the United States."

Volume 17 (April 1983), pp 95-119. Sergio Díaz Briquets. "Demographic and Related Determinants of the Recent Cuban Emigration." 
Volume 17 (Summer 1983), pp 212-244. Douglas S. Massey and Kathleen M. Schnabel. "Recent trends in Hispanic immigration to the United States."

Volume 19, \#1 (Spring 1985), pp 4-34. Silvia PedrazaBailey. "Cuba's Exiles. Portrait of a Refugee Migration."

Volume 20 (Spring 1986), pp 4-20. Lisandro Pérez. "Immigrant economic adjustment and family organization: the cuban success story reexamined."

International Perspectives. May/June 1980, pp 33-36. J.C.M. Ogelsby. "Faltering Revolution sparks mass exodus from cuba."

Jet. Volume 64 (1 August 1983), p 48. "Minoso, Oliva among 40 to Cuban Hall of Fame."

Journal of Caribbean studies. Volume 4 (Fall 1984), pp 91109. Mark F. Peterson. "Cuban Mariel boatlift refugees: employment experiences and prospects."

Journal of inter-American Studies and World Affairs. Volume 24, (May 1982), pp 183-209. Gaston A. Fernández. "The Freedom Flotilla: A Legitimacy Crisis of Cuban Socialism."

Journal of Policy Analysis and Management. Volume 5 (Fall 1985), pp 119-137. Simon M. Fuss. "Through a glass darkly: cause and effect in refugee resettlement policies."

Macleans. Volume 93 (21 April 1980), pp 33-34. William Lowther. "A spy in the ointment."

Volume 93 (5 May 1980), p 27. William Lowther. "And nobody waved goodbye."

Volume 93 (26 May 1980), p 32. John Harbran. "Strangers in a strange land."

Volume 93 (23 June 1980), p 6. Wayne Ellwood. "Share now or pay later."

Volume 93 ( 8 September 1980), p 33. William Lowther. "Despair in the promised land."

Volume 99 (21 April 1986), p 32. Peter Kiernan. "A dream in exile."

Volume 99 (25 August 1986), p 16. "Era of the homeless." 
Volume 100 (8 June 1987), p 24. "A flight to freedom."

Volume 100 ( 7 December 1987), p 24. Andrew Bilski. "Revolt of the Cubans."

Money. Volume 9 (September 1980), pp 100-106. Marlys Harris. "One extended family's finances: new Yanqui comes home."

Monthly Labor Review. Volume 103 (October 1980), pp 39-46. Robert L. Bach. "The new Cuban immigrants: their background and prospects."

Mother Jones. Volume 14 (July/August 1989), pp 20+. Saul Landau. "After Castro."

The Nation. Volume 230 (17 May 1980), p 577. "War of refugees."

Volume 230 (7 June 1980), p 673. Dagmaris Cabezas. "You can go home again."

Volume 230 ( 7 June 1980), pp 682-685. Peter Winn. "Is the Cuban revolution in trouble?"

Volume 232 (30 May 1981), p 652. "Cuban castaways."

Volume 233 (26 September 1981), pp 265-268. Ronnie Lovler. "Training for the counterrevolution."

Volume 233 (12 December 1981), p 628. Aryeh Neier. "Refugee gulags."

Volume 237 (15 October 1983), pp 332-333. Lucette Lagnado. "Anti-Castro PAC in Washington."

Volume 242 (19 April 1986), pp 537, 549-550. Walter LaFeber. "Lest we forget the Bay of Pigs."

Volume 242 (19 April 1986), pp 550, 554-557. Harold Feeney. "No regrets, we'd do it again."

Volume 245 (12 December 1987), p 701. "Come home to roost."

Volume 246 (27 February 1988), pp 260-261. Alexander Cockburn. "Beat the devil."

Volume 247 (24 October 1988), pp 389-392. John Spicer Nichols. "The power of the anti-Fidel lobby."

Volume 247 (24 October 1988), pp 392-394. Maria de los Angeles Torres. "Working against the Miami myth." 
Volume 247 (24 October 1988), pp 395-397. William M. Leogrande. "Cuba: the Democrats: a party divided and paralyzed."

National Catholic Reporter. Volume 16 (15 August 1980), p 22. "'Bad Press' creates difficulties in resettling Cuban refugees."

Volume 16 (26 September 1980), p 1. "Sponsor lack snarls life for cubans still in camps."

National Review. Volume 32 (13 June 1980), pp 722-724 E. Howard Hunt. "Castro's worms."

Volume 32 (13 June 1980), p 749. William F. Buckley. "Castro versus Miguel."

Volume 33 (20 February 1981)，pp 148-150，152，184. Francis $X$. Maier and $R$. Bruce McColm. "Nation in our midst: the Cuban diaspora."

Nation's Cities Weekly. Volume 3 (30 June 1980), p 6 . Carol Korcheisen. "Carter unveils his policy on Cubans, Haitians."

The New Republic. Volume 182 (24 May 1980), p 2. "More huddled masses."

Volume 182 (24 May 1980), pp 5-6. "A half-opened door."

Volume 182 ( 31 May 1980), pp 19-23. John Womack, Jr. "The revolution tightens its belt."

Volume 182 (21 June 1980), p 6. John Osborne. "With Open Arms."

Volume 183 (27 September 1980), pp 8-10. John Osborne. "Refugees."

New York. Volume 14 (26 October 1981), pp 67-73. Michael Daly. "Los Bandidos take the town."

The New York Times. Volume 129 (17 August 1980), p 34. Karen DeWitt. "Homosexual Cubans get settlement aid."

Volume 130 (17 March 1981), p A14. Jo Thomas. "Nicaraguans train in Florida as guerrillas."

Volume 135 (9 July 1986), p 1. Bernard Gwertzman. "Cuba, in immigration concession, said to drop American radio ban." Volume 136 (22 October 1986), p A14. "Cuban exile linked to Contras." 
Volume 136 (10 December 1986), p A21. Joseph Treaster. "Accused terrorist helping to supply the Contras."

Volume 136 (11 December 1986), p A21. Joseph B. Treaster. "Aid for the Contras: the Cubans of Miami send it with gusto."

Volume 136 (22 December 1986), p Al9. Joseph B. Treaster. "A Cuban-American adviser tells of combat with Nicaraguan rebels."

Volume 136 (26 December 1986), p A14. Joseph B. Treaster. "In the bushes of Florida, Cuban 'Brigade' tries to keep the flame alive."

Volume 136 (4 January 1987), p A8. George Volsky. "Contra supporter describes his role."

Volume 136 (22 May 1987), p A14. Bernard Weinraub. "Wooing Cuban-Americans in G.O.P."

Volume 137 (25 October 1987), p 16. George Volsky. "Conservative Cuban lobbying group opens bitter attack on Miami paper."

Volume 137 (26 December 1987), p A8. Lydia Chavez. "Returning Cuban-Americans reinforce Miami's Hispanic ties."

Volume 137 (12 January 1988), p A18. George Volsky. "Prison riots provoke debate among Cuban exiles."

Volume 137 (13 April 1988), pp Al, A19. Jon Nordheimer. "Riots discomfit the Cubans of Miami."

Volume 137 ( 23 August 1988), p A10. George Volsky. "Six indicted in scheme to train anti-Nicaraguan mercenaries."

Volume 138 (1 December 1988), p A8. "Court refuses to bar deportation; five may be sent to Cuba today."

Volume 138 ( 3 December 1988), p 8. "First 5 Cubans are returned by U.S. under pact with castro concerning criminals."

Volume 138 (12 December 1988), p A19. "185 more Cuban exiles arrive."

Volume 138 (11 January 1989), p A10. "Search for snow costs a family life in the U.S.: visit to Canada proves to be self-deportation." 
Volume 138 (17 January 1989), p A11. "Cubans who sought snow may ask for asylum."

Volume 138 (22 March 1989), p A14. George Volsky. "Castro foe reports trip to Havana and a possible thaw in hostility."

The New York Times Magazine. Volume 130 (21 September 1980), pp 45+. Herbert Burkholz. "The Latinization of Miami."

Volume 130 (21 December 1980), pp 30, 42-54. Paul Heath Hoeffel. "Fort Chaffee's unwanted Cubans."

Volume 130 (4 January 1981), pp 28-40. R. Bruce McColm and Francis $\mathrm{X}$. Maier. "Fighting Castro from exile."

Volume 136 (19 July 1987), pp 18-24, 44, 68. Robert Sherrill. "Can Miami save itself?"

The New Yorker. Volume 63 (18 May 1987), pp 65-69, 71-83. David Rieff. "The second Havana."

Volume 65 (16 October 1989), pp 51-84. Frances Fitzgerald. "Annals of Justice: Iran-Contra."

Newsweek. Volume 95 (21 April 1980), p 53. "Cubans vote with their feet."

Volume 95 (28 April 1980), pp 38-43. "The flight from Havana."

Volume 95 (5 May 1980), pp 59-60. "Sea lift from Cuba to Key West."

Volume 95 (12 May 1980), pp 60-63. "Coping with Cuba's exodus."

Volume 95 (12 May 1980), $p$ 63. "In the flotilla at Mariel."

Volume 95 (19 May 1980), pp 28-29. "The Cuban tide is a flood."

Volume 95 (26 May 1980), pp 22-28. "Carter and the Cuban influx."

Volume 95 (26 May 1980), p 31. "Refugee's lot."

Volume 95 (2 June 1980), p 40. "Cuban blockade is working--so far." 
Volume 95 (16 June 1980), pp 28-29. "Refugees: rebels with a cause."

Volume 96 (1 September 1980), p 26. "Cuban hijackers-and those who stay."

Volume 96 (29 September 1980), pp 30-31. "The Cuban conundrum." Volume 97 (9 March 1981), p 13 "Cuban refugees: a loss of hope."

Volume 98 (2 November 1981), pp 22-24. "Cuban refugees: limbo in Lima."

Volume 99 (1 February 1982), p 28. "What's become of the Cubans."

Volume 107 (31 March 1986), p 80. "The first contras." Volume 107 (28 April 1986), p 8. "Lessons from the Bay of Pigs."

Volume 107 (9 June 1986), p 28. "Men without a country."

Volume 107 (16 June 1986), p 28. "Miami muzzle: an anti-Castro test?"

Volume 108 (21 July 1986), p 21. "Adrift: Cuba's raft people."

Volume 109 (8 June 1987), p 42. "Their man from Havana: true confessions?"

Volume 110 (7 December 1987), pp 38-40. "A Cuban explosion."

Volume 110 (7 December 1987), p 43. "The men behind the prison walls: profiling the Marielitos."

Volume 110 (14 December 1987), p 53. "Lessons of the Cuban prison crisis: what the Marielitos won."

Volume 111 (25 January 1988), pp 22-29. "Miami."

Nuestro. Volume 4 (August 1980), pp 57-59, 62. Amaury Cruz . "What kind of welcome is this?"

Volume 4 (December 1980), p 9. "Cubans are OK."

Volume 9 (April 1985), pp 30-34. Toni Breiter. "The Promised Land." 
Volume 10 (January-February 1986), pp 15-17. Tom Díaz. "Miami's new Cuban-born mayor."

Penthouse. Volume 12 (February 1981), pp 75+. Lorrin Philipson. "Running from Castro."

Volume 13 (October 1981), pp 80+. Warren Hinckle and William $W$. Turner. "The mystery of 544 Camp street."

People Weekly. Volume 13 (26 May 1980), pp 28-31. "Freedom flotilla: a brave skipper, a grateful family and angry Florida critics."

Volume 14 (7 July 1980), pp 24-26. "Plagued by heat, crime and snafus, the Fort chaffee refugee camp becomes an American nightmare."

Volume 15 (9 March 1981), pp 34-36. "Pedro Rodriguez, a man with no country is a test case for the 1,700 jailed cubans."

Volume 25 (2 June 1986), pp 85-86. "Atlanta DJ raised spirits of Cubans awaiting their fate in federal prison."

Volume 28 (10 August 1987), pp 105-106. "Once a Cuban hero, Roberto Urrutia aims to give the U.S. a boost--and Castro a lesson--in the Pan Am games."

Volume 28 (21 December 1987), pp 104-106. "Miami's bishop Agustin Roman defuses a human time bomb to end the Cuban prison riots peacefully."

The Progressive. Volume 44 (July 1980), pp 36-37. Gary MacEoin. "Playing politics with refugees."

Volume 44 (August 1980), pp 44-45. Milton Mayer. "Massaging the news."

Volume 57 (January 1988), p 10. "Detention row."

Public Health Reports. Volume 100 (January-February 1985), pp 40-48. Larry B. Silver, Barbara J. Silver, Morton M. Silverman, William Prescott, Luisa del Pollard. "The Cuban immigrant of 1980: a special mental health challenge.

Public Opinion Quarterly. Volume 45 (Summer 1981), pp 245249. Michael F. Weeks and R. Paul Moore. "Ethnicityof-interviewer effects of ethnic respondents."

Reader's Digest. Volume 117 (August 1980), pp 92-96. Kenneth Y. Tomlinson. "Fleeing Cuba for freedom." 
Volume 121 (December 1982), pp 221-224. Peter Michelmore. "From Cuba with hate: the crime wave Castro sent to America."

Volume 125 (September 1984), pp 11-12. David Reed. "Carlos Pérez--hero for the 80 's."

Volume 127 (December 1985), pp 185-186. George Gilder. "Behind the Cuban-American miracle."

Volume 132 (February 1988), pp 98-102. John G. Hubbell. "operation Pedro Pan."

Reason. Volume 16 (November 1984), pp 21-28. George Gilder. "Miami's Cuban miracle."

Revista. Volume 12, \#2 (Summer, 1982), pp 201-220. Max Acrizi. "Cultural and Political Change among Cuban Americans, 1952-1982."

Rolling stone. Number 326 (18 September 1980), pp 42-44, 51 . Tom zito. "Double dealer."

Number 343 (14 May 1981), p 16. Jeff Stein. "Guerrillas in gringoland."

Number 353 (1 October 1981), pp 20-23, 101-102. John Rothchild. "Florida: sunset in the sunshine state."

Social Science and Medicine. Volume 13 (1979), pp 137-151. Mercedes C. Sandoval. "Santeria as a mental health care system: an historical overview."

Social Science Quarterly. Volume 60 (June 1979), pp 35-50. Myra Marx Ferree. "Employment without liberation: Cuban women in the United States."

Social Work. Volume 29 (March-April 1984), pp 115-121. Magaly Queralt. "Understanding Cuban immigrants: a cultural perspective."

Sociology and Social Research. Volume 65 (April 1981), pp 311-322. Douglas S. Massey. "Hispanic residential segregation: a comparison of Mexicans, Cubans, and Puerto Ricans."

Sports Illustrated. Volume 52 (19 May 1980), p 15. "Freedom."

Statistical Bulletin. Volume 69 (October-December 1988), pp 2-12. "Hispanic Americans: an emerging group." 
Television-Radio Age. Volume 35 (25 July 1988), pp A40-A44. "Florida's new Hispanic flavor."

Time. Volume 115 (21 April 1980), p 28. "Fleeing from Fidel's rule."

Volume 115 (28 April 1980), $\mathrm{p}$ 32. "Start of a mass exodus."

Volume 115 (5 May 1980), pp 42-44. "Voyage from Cuba." Volume 115 (12 May 1980), pp 36-38. "The flotilla grows."

Volume 115 (12 May 1980), p 38. "Escape from bedlam and boredom."

Volume 115 (19 May 1980), pp 14-18. "Open heart, open arms."

Volume 115 (19 May 1980), p 18. "Happy to wash dishes." Volume 115 (26 May 1980), pp 15, 18. "Carter orders a Cuban cutoff."

Volume 115 (2 June 1980), p 21. "Exodus goes on."

Volume 115 (2 June 1980), p 80. Lance Morrow. "Guarding the Door."

Volume 115 (9 June 1980), p 23. "We want out."

Volume 115 (16 June 1980), p 29. "Impatient for freedom."

Volume 116 (25 August 1980), p 40. "Havana bound."

Volume 116 (1 September 1980), pp 8-10. "Welcome wears thin."

Volume 116 (8 September 1980), p 28. "Camp of fear in Wisconsin."

Volume 116 (13 October 1980), p 45. "The Cuban refugees move on.."

Volume 117 (12 January 1981), p 52. "Refugee rights."

Volume 117 (18 May 1981), p 27. "We were poor in Cuba, but..." 
Volume 118 ( 7 September 1981), p 11. "Libre at last! Libre at last!"

Volume 118 (12 October 1981), p 31. "Miami's agony."

Volume 118 (23 November 1981), p 26. "Bridging the cultural gap."

Volume 119 (8 February 1982), p 34. "Inside Camp CubaNicaragua."

Volume 122 (12 September 1983), pp 24-25. "Working hard against an image: for America's Marielitos, the adjustment has been no easy trip."

Volume 124 (24 December 1984), p 20. "Outcasts and immigrants." Volume 125 (4 March 1985), p 29. "Adios to Cuban prisoners."

Volume 129 (8 June 1987), p 26. "Hero to go."

Volume 130 (24 August 1987), p 17. "Spilled beans."

Volume 130 (7 December 1987), pp 23-24. "We are the abandoned ones.'"

Volume 130 (14 December 1987), p 36. "Promises, promises."

Volume 131 (6 June 1988), pp 9-10. Cristina Garcia. "In Florida, soft whiffs of memory."

United states Catholic Conference, Migration and Refugee Services. Refugees from Cuba. A Look at History, Culture and the Refugee Crisis. Washington D.C., 1984 .

United States Congress. House. Committee on the District of Columbia. Cuban immigrants at Saint Elizabeth's Hospital, Washington, D.C. Committee staff report, 97th Congress, 2nd Session. United States Government Printing office, 1982 .

United States Congress. House. Committee on Education and Labor. Subcommittee on Elementary, Secondary, and Vocational Education. Hearings, 96th Congress, 2nd Session, on H.R. 7425 to amend the Indochina Refugee Children Assistance Act of 1976 to provide for assistance to educational agencies for services provided to cuban and Haitian refugee children. United States Government Printing office, 1980. 
United states Congress. House. Permanent Select Committee on Intelligence. Subcommittee on oversight. Staff Report. The cuban emigres: was there a U.S. intelligence failure? United states Government Printing office, 1980 .

United states Congress. House. Committee on the Judiciary. Subcommittee on Immigration, Refugees, and International Law. Caribbean migration. Oversight hearings, 96th Congress, 2nd Session. United States Government Printing Office, 1980 .

United States Congress. House. Committee on the Judiciary. Subcommittee on Immigration, Refugees, and International Law. Cuban/Haitian Adjustment. 98th Congress, 2nd Session, 9 May 1984 .

United states Congress. House. Committee on the Judiciary. Subcommittee on courts, civil Liberties, and the Administration of Justice. Atlanta Federal Penitentiary: report. United States Government Printing office, 1986.

United states Congress. Senate. Committee on Governmental Affairs. Subcommittee on Federal spending, Budget, and Accounting. Illegal alien felons: a Federal responsibility. Hearing, lo0th Congress, lst Session, 12 March 1987.

United states Congress. Senate. Committee on the Judiciary. Caribbean refugee crisis: Cubans and Haitians. United States Government Printing office, 1980.

United states Congress. Senate. Committee on the Judiciary. Subcommittee on Immigration and Refugee Policy. United states as a country of mass first asylum. Hearing 97 th Congress, 1st Session, July 31, 1981. United States Government Printing office, 1982.

United States Congress. Senate. Committee on the Judiciary. Subcommittee on Immigration and Refugee Policy. Hearing, 97th Congress, 2nd Session, an oversight hearing to review presidential emergency powers with respect to immigration, 30 september 1982 .

United states Congress. Senate. Committee on the Judiciary. Subcommittee on Immigration and Refugee Policy. Immigration emergency legislation. Hearing, 98th Congress, 1st Session, 28 October 1983. 
United States Department of Commerce. Bureau of the Census. "Persons of Spanish Origin in the United States: March 1982." Edward W. Fernández and Carmen DeNavas. P-20, \#396. (Preliminary report P-20, \#361).

United States Department of Commerce. Bureau of the Census. "Who are the other Spanish?" Edward W. Fernández and Arthur R. Cresce. 1975.

United States Department of Health and Human Services. Office of Refugee Resettlement. Refugee Resettlement in the United States: An Annotated Bibliography. 6 March 1981.

United states Department of Health and Human Services. Cuban/Haitian Task Force. Cuban/Haitian Entrant Program operating Manual. Washington D.C. 20 March 1981.

United States Department of Health and Human Services. Social Security Administration. Office of Refugee Resettlement. Report to congress. Refugee Resettlement Program. Reports from 31 January 1981; 31 January 1983; 31 January 1985; and 31 January 1988.

United states Department of Justice. Community Relations Service. Cuban/Haitian Entrant Program. Special Placement Program. Program Description and Requirements. 12 April 1988.

United States Department of State. Bureau of Public Affairs. Gist. July 1980. Report on Cuban-Haitian entrants.

United States Department of State. Robert L. Bowen, editor. A Report of the Cuban-Haitian Task Force. Washington, D.C., 1 November 1980.

U.S. Naval Institute Proceedings. Volume 106 (October 1980), pp 44-51. Robert L. Scheina. "The cuban Exodus of $1980 . "$

U.S. News and World Report. Volume 88 (21 April 1980), p 13. "Why 10,000 Cubans grab chance to leave."

Volume 88 (28 April 1980), p 7. "Life in Cuba: I was like a robot."

Volume 88 (5 May 1980), pp 41-42. "Cuba's boat people-dilemma for Carter."

Volume 88 (12 May 1980), p 55. William L. Chaze. "Can Miami cope with new flood of refugees?" 
Volume 88 (19 May 1980), p 8. "For Cubans: hospitality and hostility."

Volume 88 (26 May 1980), pp 21-22. "Cuba's tattered economy--through refugee eyes."

Volume 88 (26 May 1980), pp 23-24. "Put limits on Cuban refugees?"

Volume 88 (2 June 1980), p 26. William L. Chaze. "Dispersing Cubans easier said than done."

Volume 88 ( 9 June 1980), p 13. "When Cubans bolt refugee centers."

Volume 88 ( 9 June 1980), p 62. "Cuban sealift: all in day's work for coast Guard."

Volume 88 (16 June 1980), p 29. William L. Chaze. "In the last days of Cuban boatlift."

Volume 89 (1 September 1980), p 8. "For most Cubans, U.S. a happy haven."

Volume 96 (16 January 1984), pp 27-30. "Castro's crime bomb inside U.S."

Volume 100 (21 April 1986), p 36. "La Causa lives on: 25 years after the Bay of Pigs."

Volume 102 ( 8 June 1987), p 12. "Just how big a fish is the man from Havana?"

Volume 103 (7 December 1987), pp 20-22. "The flames of fear; has the United States played straight with the Cuban Marielitos?"

Volume 106 (9 January 1989), p 41. Anne Moncreiff Arrate. "The quiet rise of the yucas in America."

Wall Street Journal. 13 November 1985, pp 1+. Roger Lowenstein. "Blending in: Cuban arrivals of 1980 hit Miami very hard, but assimilated well."

2 June 1986, p 1. Sonia Nazario. "Freedom of speech is a debatable issue in Miami."

16 January 1987, p 1 . José De Cordoba and Thomas E. Ricks. "Cuban connection: Bay of Pigs veterans find in Nicaragua a new war to fight." 
2 November 1988, p Bl. "Hispanic groups show wide diversity."

Washington council for inter-American Security. The 1980 Mariel Exodus: an assessment and prospect. 1981.

Washington Post. 26 October 1986, pp Al, A40-41. Julia Preston and Joe Pichirallo. "Bay of Pigs Survivors Find Common Cause with Contras."

Wilson Quarterly. Volume 9 (Winter 1985), pp 47-69. Barry B. Levine. "Miami: the capital of Latin America."

Volume 9 (Winter 1985), pp 70-75. George Gilder. "Making it."

World Press Review. Volume 27 (June, 1980), p 20. "Escape from Paradise."

Volume 27 (August, 1980), p 16. "The Cuban Affair."

Youth \& Society. Volume 11 (June 1980), pp 431-447. J. Bryan Page. "The children of exile: relationships between the acculturation process and drug use among cuban youth."

\section{OREGON ASPECT}

\section{Periodicals}

Capital-Journal. 12 June 1980, p 1A. Martin Rosenberg. "Cubans glad to be in U.S., but jobs are hard to find."

Catholic sentinel. (Also contains numerous articles throughout 1960s on the situation in Cuba.)

26 January 1961, pp 1, 24. "Aid sought for Cuban refugees: Father Park to attend Miami meet."

9 February 1961, pp 1, 24. "Group to plan local aid for Cuba refugees."

9 March 1961, p 1. Photo announcing arrival of Elena Rodríguez.

16 March 1961, p 5. "Governor commends work of resettlement group."

23 March 1961, p 8. Tom Albright. "First Cuban refugee family arrives, engineer tells of symbol war." 
1 June 1961, p 6. "Refugee problems told at world affairs meet."

22 June 1961, p 14. "Charities total reaches $\$ 50,000$; advisory board hears Cuba refugee."

3 August 1961, p 3. "Refugee family arrives from Cuba."

5 October 1961, p 16. "Quiet desperation' in refugee groups reported by Fr. Park."

26 October 1961, p 10. Thomas Albright. "3rd Cuban refugee family arrives to make home in Portland area."

30 November 1961, p 10. "Appeal made for sponsors of new Cuban refugees."

30 November 1961, p 25. Thomas Albright. "Cuban, once jailed by Castro forces, joins sister in Portland."

7 December 1961, p 1. "Part of $\$ 19,000$ bequest to aid Cuba refugees."

4 January 1962, p 5. Thomas Albright. "Refugee Cuban attorney relates experiences under Castro rule."

15 March 1962, p 21. Thomas Albright. "Refugee program cares for 41 children."

5 April 1962, p 5. "Two more Cuban families arrive in Archdiocese."

30 August 1962, p 21. "Mass set for Cubans."

8 August 1963, p 8. "Protestant-sponsored Cuban refugee families seek jobs in Portland area."

26 september 1963, p 8. "Charities officials honored for work among refugees."

29 October 1965, p 20. "Charities unit preparing for new Cuba refugees."

8 April 1966, p 18. "Bureau reports on Cuban program."

9 September 1966, p 1. "Father Park new pastor."

13 June 1980, p 3. "Church primed to help refugees."

17 October 1980, p 18. "Father Kennard to work with Cuban refugees." 
9 January 1981, p 1, Robert Gabriel, 2 a rt i c 1 e s . "Portland family accepts youth, 19." "Priest seeks out refugee sponsors."

16 January 1981, p 1, Robert Gabriel. "Time running out for Cubans here."

Oregon Journal. 27 June 1958, p 1. "Cuba rebels grab Portland engineer."

28 June 1958, p 2. Larry McCarter. "Wife recalls kidnapped husband reluctant on Cuba assignment."

3 July 1958, p 1. "Cuba-held hostages to go free."

13 August 1959, p 7B. Doug Baker. "Now it can be told: Cuban consul escapes Vancouver police guns."

8 February 1961, p 3. "Plan to resettle Cuban refugees here."

1 March 1961, p 1. "Agency places first Cuban refugee here."

25 December 1961, p 8. "Cubans celebrate Yule here."

10 March 1962, p 9. "Refugee help gets new push."

10 March 1962, p 10. "Two Cuban refugee families reunited."

28 March 1962, p 3. "More Cuban refugees due here."

19 October 1962, p 4. John McWilliams. "Cuban youths here turn to newspaper deliveries."

26 October 1962, p 4. Doug McKean. "Hatfield: Cuba debate adequate."

26 October 1962, p 6. "Anti-Cuba blockade march little heeded."

27 October 1962, p 2. Doug McKean. "Candidates head into home stretch." P 10. "Russians manning the pads, Morse says."

29 October 1962, p 10. Doug McKean. "Unander supports Kennedy on Cuba."

30 October 1962, p 2. Tom Stimmel. "Morse backs earlier 'Cuba thorn' label." 
14 December $1962, \mathrm{p}$ 1. John McWilliams. "Cubans here appeal to JFK."

26 December 1962, p 5. John McWilliams. "Cuban refugees in Portland feel certain Castro on way out."

1 January 1963, p 6. John McWilliams. "Portland refugees feel hopeful."

2 February 1963, p 9. "Protestants to bring Cuban refugee group."

26 February 1963, p 15. "Red Cross opens English class for Cuban refugee workers."

23 March 1963, p 3. John McWilliams. "200 Cuban refugees live here."

18 May 1963, p 9. "Protestants to help resettle Catholics."

3 July 1963, p 2. "Cuban refugees conquer America--by car."

3 July 1963, p 12. "Tourists' to Cuba assailed."

11 September 1963, section 2, p 3. "Seventy Cuban refugees to arrive."

12 September 1963, p 3. Bill Shreve. "Eleven Cuban optometrists arrive for Pacific University study."

7 December 1963, p 2. John McWilliams. "Porter's eulogy attacked."

28 May 1964, p 5. "Realty board honors Cuban refugee family."

24 July 1964, p 5. John McWilliams. "PSU's Peace Corps trainees teach Cubans English."

14 November 1964, p 3. Miles Green. "Cuba exile strives to save parents."

24 November 1964, section 2, p 1. "Thanksgiving first for Cubans."

11 February 1965, p 3. John McWilliams. "Cuban family together again, but son, 9, must learn Spanish."

21 July 1965, section 2, p 11. "Schools absorbing displaced Cubans." 
22 December 1965, p 2. Miles Green. "Youth, Cuban refugee parents reunited after 4 years."

3 May 1967, p 4. Bill Collins. "Flight from Red terror ends in Rose Festival Court."

6 June 1967, p 1. "Lovely Jefferson High Cuban wins crown." $P$ 8. Marge Davenport. "students strew rose petals to welcome Queen."

30 June 1967, p 5. Dave Davis. "Cubans bring twins, infant here."

26 September 1967, p 1. "Yankee, Si."

23 December 1967, p 2. John McWilliams. "T. Utrera family will testify good neighbor policy exists."

22 November 1968, section 2, p 1. Helen L.Mershon. "Cubans ride old crop duster to freedom."

27 January 1969, section 2, p 1. Suzanne Richards. "County hospital gift to honor Cuban patriot."

7 February 1969, p 4. John McWilliams. "2 Cuban families honored."

24 April 1969, p 32. John McWilliams. "Shortages of shoes impede flight of Cuban refugees."

30 January 1970, p 5. John McWilliams. "Cubans honor Portland baby."

13 February 1970, p 2. John McWilliams. "U.S. lauds Cuban pair here."

16 February 1970, p 2. John McWilliams. "Refugee Cubans say cane cutters misled."

22 March 1972, p 2. "Communist fighter speaks out."

26 September 1977, p 1. Douglas Yocom. "Cuban-born lawyer chosen successor to Sen. Roberts."

28 September 1977, p 14. "New face for State Senator." 8 May 1980, p 4. Watford Reed. "Portland Cubans frustrated in relative rescue attempts."

10 May 1980, p 1. Dennis McCarthy. "Cuban refugees to start new lives in Portland." 
3 April 1982, p 10. Jim Running. "Cheers, hugs greet first ' 82 Rose Festival princess."

The Oregon Optometrist. Volume 30 (July-August 1963), pp 1415.

The Oregonian. 28 June 1958, p 1. "Cuban rebels nab Portland man in raid." Section 3, p 2. "Portland family of kidnap victim tries not to worry about father."

3 July 1958, p 1. "Cuban rebels release 5 of 49 kidnapped Americans: Portlander with men flown out."

14 August 1959, p 18. "Vancouver police reveal arrest of Cuban consul."

8 February 1961, p 8. "Catholic parishes plan aid for Cuban refugees."

2 March 1961, p 6. William Hilliard. "Church sponsors bring Cuban visiter to city."

19 March 1961, p 33. William Hilliard. "Cuban refugees now in Portland say people afraid to revolt against Castro regime."

19 April 1961, p 12. "Cuban refugee in Portland holds hope for Castro's overthrow."

13 December 1961, p 17. "Cuban attorney, family, paint grim picture of life under castro for those left behind."

7 March 1962, p 7. William Swing. "Cuban refugees in Portland says Castro figurehead, foresees rift between factions."

8 March 1962, p 1. "Tidal wave of Cuban children flows silently out of country."

11 March 1962, p 30. "Cuban families arrive in Portland, reunion with children awaits them."

6 May 1962, p 50. John Harvey. "Cuban family of twelve starts new life in city."

23 October $1962, \mathrm{p} 3$. "Cubans living here express war doubts."

25 November 1962, p 48. William Sanderson. "Agencies labor to aid local cuban refugees help themselves." 
28 January 1963, p 13. Robert Olmos. "English poses awesome barrier to Cuban refugees in Portland."

31 January 1963, p 13. Robert Olmos. "Cuban refugees tell of hazardous escape."

19 February 1963, p 4. "Eugene woman's spouse freed from jail."

15 May 1963, p 15. "Cuban-Jewish family now 'home' after losing property to Castro."

4 July 1963, section 3, p 7. "Cuban refugees cross U.S. by car, prepare for new life in Portland."

14 August 1963, p 15. "10 Cuban refugees plan 2 year study at Pacific."

17 August 1963, section 2, p 2. Nancy Morris. "Wife of Spanish instructor provides students with lessons, Cuban food."

2 September 1963, p 17. "City's open mass September 8 for cuban refugees contrasts with island's hidden candles."

22 October 1963, p 7. Leverett Richards. "Cuban crisis came home to oregon a year ago."

24 October 1963, p 24. Robert Olmos. "Cuban flees homeland in eight-foot open boat."

8 December 1963, section 2, p 2. "Refugee work to be topic."

9 January 1964, p 17. "Cuban seeks names list."

17 August $1964, \mathrm{p}$ 25. Peter Tugman. "Oregon student home after stay in Havana."

30 August $1964, \mathrm{p} 26$. "Besos y abrazos greet families of Cuban refugee students studying at Forest Grove."

10 November 1964, p 25. "Cuban finds home here."

15 November 1964, p 38. "Young Cuban labors to fly parents out."

13 January 1965, p 7. "Cuban refugees family receives Red Cross aid." 
22 January 1965, p 13. "Cubans' writings ring with harshness of past."

12 February 1965, p 21. "Cuban parents, reunited after 3 year separation."

children

13 October 1965, p 8. "Church seeks to aid Cubans."

23 December 1965, p 16. "Cuban mother sees son after 3 year delay. First Cuban refugee to arrive, Mrs. Modesta G. Herrada."

26 December 1965, p 53. "Cuban refugees arrive for Portland reunions."

28 June 1966, p 12. "Cuban aided by Portlanders now helps others."

26 January 1967, p 20. "Cubans plan Martí fete."

4 May 1967, p 1. Ann Sullivan. "Jefferson picks refugee as festival princess."

6 June 1967, p 1. Ann Sullivan. "Queen Ana Maria rules over Portland Rosaria."

28 July 1967, p 25. Blaine Schulz. "15 refugees prepare for teaching careers."

27 September 1967, p 11. "Rose Queen new citizen."

31 December 1967, p 1. Judd Smith. "Family of 11 moves to Portland."

29 January 1968, p 19. "Club opened by exiles, place provided for meetings."

11 April 1968, p 38. Robert olmos. "Newly arrived refugees says Castro willing to let aged, ailing leave cuba."

21 July 1968, p 28. Robert Olmos. "Refugee family describes ordeal suffered in escaping from Cuba."

29 January 1969, section 2, p 11. Robert Olmos. "Eight pound boy receives gifts from Cuban club."

7 February 1969, p 29. "Two Cubans honored for outstanding activity."

8 December 1969, p 24. Kernan Turner. "Cuban refugees arriving in Portland find home, food already provided." 
22 May 1971, p 12. "Ex-migrants earn degrees."

21 November 1971, p 44. Janet Goetze. "Cubans adjust to U.S.Iife."

12 June 1972, section 2, p 7. "Cuban refugees in Portland continue to fight to free native land."

30 August 1973, p 23. Robert Olmos. "Doctor from Cuba seeks U.S. toehold."

2 November 1975, p D8. Ed Mosey. "Portlander has aided refugees since $1945 . "$

28 April 1977, p DI. Andrew Mershan. "Portlander visits Cuba."

27 September 1977, p A1. Stan Federman. "Cuban immigrant named to state senate seat." P D22. Stan Federman. "Man in the news: Soto-seelig determined to make place for himself."

6 October 1977, p Cl. Robert Olmos. "Soto-Seelig fills Roberts' shoes--and then some."

3 August 1978, p B3. Early Deane. "Portlanders Cuban stay to end."

6 August 1978, p G10. "Couple arrested after Cuba exile."

8 August 1978, p All. John D. Hopkins. "Innocent pleas filed in hijacking."

13 May 1980, p B4. Julie Tripp. "Cuban refugees tell of Castro's repression."

13 July 1980, p D11. Steve Erickson. "Cubans find language greatest barrier."

17 January 1981, p A17. John Guernsey. "Cubans reunited through dentistry."

3 April 1982, p Cl. "Cuban emigre gets crown as Franklin picks princess."

4 May 1982, p Bl. Benny Evangelista, Jr. "Cuban lays woes to federal policies."

24 August 1983, p B2. Paul Manley. "Journalist happy she put her children in Cuban schools." 
11 September 1983, p C4. Dane Claussen. "Many Cuban refugees still find life, customs difficult in Portland."

8 January 1984, p C1. John Enders. "Light of hope, opportunity lures Cubans."

8 April 1989, p D1. "St Mary's names princess."

3 June 1989, p 1. Barnes C. Ellis. "Queen Deanna wins crown."

Pacific Today. Volume 2 (Fall 1967), p 2.

Portland Reporter. $\quad 19$ November 1962, p 14. Stephanie Pulakis. "Designated by regime as worm, Cuban boy left home for freedom."

4 July 1963, p 21. Dana Lothian. "2 Cuban families find refuge in Portland, say everything goes to pay Russians for bullets."

10 August 1963, p 14. Bob Larson. "Cuban refugees making good adjustment here."

19 August 1964, p 6. Bill Ellis. "Cuba visiting Aloha student denies FBI request to testify on action."

Statesman-Journal. 7 June 1980, p 7C. "Cubans are finding homes in Oregon without fanfare."

8 April 1986, p 9A. "Promises versus performance."

Willamette Week. Volume 8, Number 30 (25 May 1982), pp 1, 67. Keith Moerer. "First year Latins."

Volume 11, Number 32 (13 June 1985), p 3. Linda Keene. "Portland's Cuban connection."

\section{Non-Periodical Sources}

Archival Material

Enriquez family archival material.

Multnomah County Archives and county clerk's office files.

Multnomah County Library.

oregon State Archives, Salem, Oregon. 
oregon State Library, Salem, oregon. Portland City Archives.

Portland State University Population Research and Census Center.

Papers of Raúl Soto-Seelig, courtesy of Elsa Seelig.

United States Department of Justice. Immigration and Naturalization Service, statistical section Reading Room.

United states Department of Justice. Immigration and Refugee Affairs office file material.

Willamette University. Papers of Governor Mark Hatfield, Mark Hatfield Library.

Catholic Welfare Bureau, Inc. Administrative Manual.

Oregon Commission on Hispanic Affairs. Biennial Report of the oregon Commission on Hispanic Affairs. June, 1989.

Interviews

Frank Algeciras--Cuban-American

Herminia Arias--Cuban-American

José Calderon, Jr.--Cuban-American

Rafael Cancio, Jr.--Cuban-American

Agustin Enriquez, Jr.--Cuban-American

Daniele Fajardo, Jr.--Cuban American

Gladys Fajardo--Cuban-American

Margaret Godfrey--Resettlement Division of Catholic Charities

Ada Hernandez--Cuban-American

Armando Laguardia--Cuban-American

Consuelo Lightner--Cuban-American

Father Morton Park--Resettlement Division of Catholic Charities 
Santiago 'Pepe' and Chani Perera, Jesus and Clara Guerra-Cuban-Americans

Charles 0. Porter--Former Oregon Congressman

Emilio, Consuelo, Eduardo, Eileen Rodriguez--CubanAmericans

Conversations

Terry Aiken--Curator, oregon Military Museum Myrna Almodovar--Church World Service, New York

Dr. William Baldwin--University of Houston, College of optometry

Ceceila Barecevich--Catholic Family Services

Ginny Bass--Portland, Oregon

Elda Becerra--Cuban-American

Dick Celsi--Portland, Oregon

Ivonne Maria Maribona Connell--Cuban-American

Sherri Cook--oregon state Refugee office

Tomas Cueva--Oregon Council for Hispanic Advancement

Sherwin Cullison--Adult and Family Services Division

Emma Dennis--st Mary's of the Valley

Dr. Rod Diman--Portland state University

Larry Dunham--state Department Protocol office, Washington D.C.

Cecil Edwards--oregon state Historian

Robey Eldritch--oregon state Corrections

Dr. M. E. Ensminger--Clovis, California

Pablo Fajardo--Cuban-Americans

Virginia and David Fajardo--Cuban Americans

Berta Feran--Cuban-American 
Lenore Frimoth--Sponsors ' Organization to Assist Refugees orlando Fuentes--Cuban-American

Eunice Goetz--Oregon Commission on Hispanic Affairs

Pamela Hall--Lincoln High School

Harold Magee--Woodburn, Oregon

Meredith McVicker--Professor, emeritus, Pacific University education division

Ron Munia--Health and Human Services Refugee Office, Washington D.C.

Paul Nagel--Portland, Oregon

Dr. James Oldfield--Oregon State University

Elvia Pérez--Cuban Refugee Center, Miami, Florida

Sorina Rio Seco--Cuban-American

Elsa Seelig--Cuban-American

Son Do Van--Region 10 Refugee office, Seattle, Washington Elena Rodriguez--Cuban-American, Catholic Family Services Ron Spendel--Oregon state Refugee office Alex Toth--Pacific University Archivist Sandra Weronko--Willamette University Librarian 


\section{ESSAY ON SOURCES}

The material about cuba's background prior to the Revolution was drawn primarily from the books listed in the bibliography. Pérez and Thomas have provided particularly valuable overviews of the island's entire history, while Farber, Foner, Gellman, Morley, and Robert Smith all shed light on twentieth century Cuban events and relations with the United States. Former Ambassadors Earl Smith and Bonsal reflected official American thought in the crucial period during and just after the Revolution, while Matthews' book has the major advantage of the author's personal experiences in the Sierra Maestra and later with the Cuban leaders. Scholars are particularly fortunate to have available relatively large numbers of works by Cuban nationals: Marti, Rubens, Suárez, Batista, and Casuso's books all contributed to this study and do not exhaust the list. Che Guevara's books are crucial to understanding the insider point of view during the period.

The remainder of the cited books bear on specific points or are part of the information explosion on the subject of transplanted Cuban-Americans, which has continued to gather momentum in the years since the migration began. MasudPiloto's approach has particular value for the historian. 
Carlos Cortes' compilation of relevant documents and testimony is noteworthy.

Various disciplines have contributed to the effort to understand the transplanted community. Hispanic Mental Health Research contains a wide-ranging bibliography dealing with adjustment problems of exiled cubans from a psychological perspective. A view uniquely designed to bridge the gap between techniques growing from the experiences of developed nations, and a mind-set more strictly cuban is attempted by Mercedes Sandoval in "Santeria as a Mental Health Care System: An Historical Overview."1

Demographic studies comprised another major attempt to define the cuban presence in the United states. Rafael Prohías' 1972 study was an early important example, ${ }^{2}$ while his later work, articles contained in American Demographics and National Journal, the various Census Bureau studies, and most importantly, an article in cuban studies in January of 1977 have continued this approach. ${ }^{3}$ other primarily statistical approaches have been offered. The best of these include an article by James D. Gwartney and James E. Long on relative

1 Mercedes S. Sandoval, "Santeria as a mental health care system: an historical overview," Social science and Medicine, Volume 13, 1979, pp 137-151.

2 See New York Times, 12 December 1972, p 19.

3 Alejandro Portes, Juan M. Clark, and Robert L. Bach, "The new wave: a statistical profile of recent cuban exiles to the United States," Cuban Studies, January 1977, pp 1-32, 
earnings, ${ }^{4}$ which reported a generally high level for cubans compared to other minorities; several studies dealing with ethnicity and fertility, 5 which emphasized cubans' low fertility; and a study by Myra Max Ferree which reflected a trend in modern scholarship by focusing on the economic situation of Cuban women. ${ }^{6}$

certainly many of the articles and studies which assert the relatively prosperous economic situation of CubanAmericans are based on mathematical evidence, although to date Marxist evaluation of the data is not prevalent. The best of the analyses favoring a political science approach are the books of Fagen and his collaborators, and Gallagher's excellent title, The cuban Exile. These efforts to unravel the political sources of the original movement from the island, and corresponding political attitudes are worthy studies.

An area of prolific output on the topic, which yet remains somewhat distant to the non-specialist, is that

4 James D. Gwartney and James E. Long, "The relative earnings of blacks and other minorities," Industrial and Labor Relations Review, April 1978, pp 336-346.

5 Mary M. Kritz and Douglas T. Gurak, "Ethnicity and Fertility in the U.S.: an analysis of 1970 public use sample data," Review of Public Data Use, May 1976; pp 12-23; Douglas T. Gurak, "Sources of ethnic fertility differences: an examination of five minority groups," Social Science Quarterly, September 1978, pp 295-310.

${ }^{6}$ Myra Max Ferree, "Employment without liberation: Cuban women in the United States." Social Science Quarterly, June 1979, pp 35-50. 
produced by the sociologists. Attempts have been made to study various aspects of life: absorption and assimilation; rates of residential segregation; educational, geographic, and income mobility; all based on dissecting social processes or "the micro data of socio-economic life." 7 The work of Alejandro Portes has been seminal in the field, and his relatively readable style is refreshing. An example of firstrate sociological writing about a particular cuban community in the United States is Eleanor Rogg's study of the New Jersey refugees, The Assimilation of Cuban Exiles.

Another genre of literature that appeared concerning the Cuban-American community focused on the stories of individual migrants with an eye towards creating a wider view, usually drawn from oral histories. The appeal is an old one in context of the cuban migration: the tales of individuals overcoming difficult obstacles before arriving in Southern Florida have appeared since Castro's overthrow of Batista. At least three books adopted this vignette style in an effort to transmit the history and culture of the arriving cubans. ${ }^{8}$

7 A. Jorge and R. Moncarz, "The golden cage--Cubans in Miami," International Migration, volume 25 (September 1987), p 267.

8 Lorrin Philipson and Rafael Llerena, Freedom Flight (New York, 1980); Jose Llanes, Cuban Americans: Masters of Survival (Cambridge, Massachusetts, 1982); Facts About Cuban Exiles, Tercer Aniversario/Puente Mariel--Key West (Miami, Florida, 1983). 
An alternative attempt to outline a Cuban-American national character began with a brief statistical base and then ambitiously turned towards "an understanding of cuban culture and psychosocial characteristics;" while not altogether convincing, the effort was commendable. ${ }^{9}$ Reliance on a right-wing political perspective animated some analyses of the Cuban-American community. ${ }^{10}$

Many of the oregon newspaper articles were found in the newspaper index prepared by the Portland city library, but has been significantly expanded. The Catholic sentinel is unindexed, thus retrieval of a subject involves week by week reading of the new microfilm version contained at the paper's office.

Official records are sparse, inasmuch as systems used by oregon in the 1960 s and 1970 s were inadequate to allow retention of permanent information files. Oregon's small size contributed to disinterest at the federal level, while reshuffling of Departmental responsibilities also helped make information about the state difficult to obtain. The search for resettlement figures led for a time into a closed loop where Oregon refugee officials tendered washington, D.C., counterparts, who, in turn, referred the writer to Florida,

9 Magaly Queralt, "Understanding Cuban Immigrants: a cultural perspective," Social Work, March-April 1984, pp 115121.

10 See, for example, Council for Inter-American Security and Heritage Foundation reports. 
who recommended District headquarters in seattle, who said that the only available records were back in state headquarters in Salem. The paucity of information about the state also included private agencies, who, at both the national and local levels, denied the existence of any concrete records. The clear exception to this rule was the Catholic Archdiocese, which while lacking clearly organized files, was both extremely helpful and ultimately successful in providing relevant documents and information.

Contacts within the cuban community provided a welcome relief from such bureaucratic madness. Most contacted individuals were extremely generous with their time, and excellent situations developed as a result of the openness offered by Oregon's Cuban-Americans. The writer's Spanish was essential to this part of the project, although it is clear that future researchers would be greeted with warmth regardless of language facility. 


\section{APPENDIX}

The right-wing political and terroristic activities undertaken within the Cuban-American community make for exciting reading. Cubans' passion for politics is widely declaimed, and early post-revolution arrivals in North America quickly turned their hands to political organization. American policy-makers continued to play a key role in cuban politics by giving public support to an organization called the Cuban Revolutionary Council. Council leadership fell to Dr. José Miró Cardona, the first premier in the new Castro government, who helped set the pattern of Fidelistas falling from power and then turning against their former comrade. By April of 1963 Miró Cardona was forced to resign from leadership of the movement; meanwhile, numerous small groups of exile raiders were executing sporadic hit and run raids against the cuban regime.'

1 other early leaders included Manuel Ray, whose numerically significant Revolutionary Movement of the People reflected his relatively leftist bent, and Dr. Antonio de Varona Laredo, who headed a loose group called the Democratic Revolutionary Front. Harold H. Martin, "Angry exiles in Florida," Saturday Evening Post, 8 April 1961, p 19, introduces shadowy groups such as the Triple $A$, headed by Sanchez Arrango, and the 30th of November Movement, whose chief was called Alejandro. "Every exile is an island," Newsweek, 29 October 1962, p 44, adds Alpha 66 to the cast. At the time of Miró's resignation, Alpha 66 , the Revolutionary Student Directorate, the 2nd Front of Escambray, and Commando $C$ were carrying out active operations against castro. See Antonio de la Carrera, "Cuba: What Now?," The New Leader, 13 
By July 1964 the New York Times Magazine reported that "several of the exiles' action groups have once more assembled power launches, weapons, and explosives."2 Early starters in the field, which included Manuel Ray's Revolutionary Movement of the People and 2nd Front of the Escambray, had been joined by a newly rightist Peoples' Revolutionary Front Movement, whose leader Major Eloy Gutierrez Menoyo rejected Ray's moderate bent. At the same time, a former figure from la brigada, Captain Manuel Artime Buesa, had founded the Movement of Revolutionary Recovery, which was "believed by many" to have CIA links. ${ }^{3}$ Artime's star was clearly on the rise in this period, and the exile groups were able to establish bases in the Dominican Republic, Costa Rica, and in Nicaragua with the help of President Somoza. ${ }^{4}$ There was reported activity

May 1963, pp 3-6, for a summary of this period. Raúl Chibás and Rogelio Cisneros were added to the list of prominent early leaders when the American government-backed strategy of forming a substantial opposition failed. The irony of antiFidel plotters replacing the late 1950s anti-Batista planners should be noted, see "How plotters use U.S. to hatch revolts," U.S. News, 22 August 1958, pp 69-71.

2 Tal Szulc, "Guerra--still the word in Miami," New York Times Magazine, 5 July 1964, pp 9+.

3 New York Times Magazine, 5 July $1964, \mathrm{p} 9+$.

4 "Coming: New Effort to Topple Castro?" U.S. News and World Report, 11 May 1964, p 39; Al Burt, "Cuban Exiles: The Mirage of Havana;" The Nation, 25 January 1965, pp 76-79; Walter LaFeber, "Lest We forget the Bay of Pigs." The Nation, 19 April 1986, p 537. The Costa Rican effort proved shortlived. 
by la brigada veterans in the congo in 1964,5 while a mortar attack near the United Nations, also in 1964, highlighted the period's domestic activities by the Cuban-American terrorists.

A team of Cuban-born, U.S. army-trained Bay of Pigs veterans led Bolivian Rangers in the successful capture and execution of Che Guevara in $1967 .^{\circ}$ CIA sponsorship of the exiles peaked in the mid-1960s, before President Johnson began to dry up the funds in $1965 .^{7}$ Before this presidential action, the Miami office of the CIA was the agency's largest and employed significant numbers of Cuban-Americans. Exiles played a prominent role in operation Mongoose, the longrunning series of plans designed to assassinate or otherwise discredit Premier Castro.

5 Harold Feeney, "No regrets--we'd do it again." The Nation, 19 April 1986, pp 549-550.

6 "Cuban extremists in U.S. a growing terror threat," U.S. News and World Report, 6 December 1976, pp 29-32; Julia Preston and Joe Pichirallo, "Bay of Pigs Survivors find common cause with Contras." Washington Post, 26 October 1986, pp 1, 40-41.

7 The best discussions of this era are contained in Dick Russell, "Little Havana's reign of terror," New Times, 29 October 1976, pp 36-45; George Crile III, "Our heritage--the exile Cuban terrorist;" Washington Post, 7 November 1976, pp C1, C3; "Cuban extremists in U.S.: A growing terror threat," U.S. News and World Report, 6 December 1976, pp 29-32; William Lowther, "The enemy grows older; and if cuba's exiles are right, more vulnerable," Macleans, 24 July 1978, pp 22-27; R. Bruce Malcolm and Francis X. Maier, "Fighting Castro from exile." New York Times Magazine, 4 January 1981, pp 28-40. See Warren Hinckle and William W. Turner, "The mystery of 544 Camp Street," Penthouse, October 1981, pp 81t, for further discussion of the connections between the exile community, the CIA, and organized crime, a link mentioned by Didion, p 153. 
New leaders emerged among the Cuban terrorists during this period, most importantly Orlando Bosch, whose 1968 bazooka attack against a Polish ship anchored in Miami provided an early event in a long career of reputed associations with terroristic activities. By early 1966 a durable organization named Alpha 66 was founded. The title had been carefully chosen by its leaders to reflect their claim that 1966 marked the beginning of Castro's fall from power. After the well-documented association of some CubanAmericans with CREEP during the 1972 presidential election campaign, an arrangement was formed between DINA, the chilean secret police, and part of the cuban exile community, which led to various activities including the assassination of orlando Letelier by a Cuban hit team in Washington, D.C., in $1976 .^{8}$ Chilean President Augusto Pinochet received la brigada's First Freedom Award in 1975, and Anastasio Somoza, the Nicaraguan president, attended the organization's September 1976 meeting.

Cuban-Americans actively participated in special operations carried out during the vietnam war. In 1973 a high-level organizational meeting, featuring a prominent level of Cuban-American exile participation amid the international

${ }^{8}$ See Saul Landau and Ralph Stavins, "The Letelier/Moffit Murder: This is how it was done," The Nation, 26 March 1977, pp 358-360, John Dinges and Saul Landau, Assassination on Embassy Row (New York, 1980), Didion, pp 156-159. 
ambience, was held in San Juan, Puerto Rico. A second conference occurred in the summer of 1976 when CORU-Coordination of United Revolutionary Organizations--designed to attack cuban diplomatic missions, was formed. As part of the Cuban community began to consider the possibilities in a softer stand towards the Castro regime, the extremists began to target domestic enemies. In 1975 and 1976, and again at the end of the decade, a spate of bombings and murders rippled through the Cuban communities in Miami and outside of New York City. ${ }^{9}$ A October 1976 Air Cubana crash was the work of the exile terrorists. ${ }^{10}$

Cocaine began to be mentioned in connection with cuban exiles during the latter part of the decade," the cuban trafficking connection apparently became more important after Mariel. ${ }^{12}$ Exiles were involved in the CIA's plan to

9 Several magazines provide lists of active groups : "Cuban extremists in U.S. a growing terror threat," U.S. News and World Report, 6 December 1976, p 32--Alpha 66, Abdala, Cero, FLNC, Pragmatistas; and "Miami, Haven for Terror," The Nation, 19 March 1977, pp 326-331--Cuban Action Movement and F-14 Cuban Nationalist Movement. Omega Seven and Brigade 2506 are mentioned throughout the literature. See also Didion, pp 99-108.

10 Washington Post, 7 November 1976, pp Cl, C3.

11 Russell in New Times; Francis X. Maier and R. Bruce McColm, "Nation in our midst: The Cuban Diaspora;" National Review, 20 February 1981, pp 148+; John Rothchild, "The Informant." Harpers, January 1982, pp 29-39.

12 See Tom Zito "Double Dealer"; Rolling Stone, 18 September 1980, pp 42+; Herbert Burkholz, "The Latinization of Miami; New York Times Magazine, 21 September 1980, pp 45+; John Rothchild "Florida: sunset in the sunshine state"; Rolling stone, 1 October 1981, pp 20+; David Rieff, "The 
assassinate Panamanian leader Omar Torrijos. ${ }^{13}$ Fragmentary reports of early involvement by Cuban-Americans in the training of Nicaraguan opponents of the sandinista regime, later known as Contras, appeared early in the decade, but were ignored until late 1986, when the wider scope of American involvement with the contras was made public. ${ }^{14}$ The emergence of organized gangs of Marielitos in the New York City area, of sponsorship by Reverend Sun Myung Moon's Unification Church in the shadowy zones of omega seven and Cero operations in West New York, New Jersey, and hints about the potentially lethal side of santeria as practiced by some Cubans further

second Havana," New Yorker, 18 May 1987, pp 65-83; and "Miami." Newsweek, 25 January 1988, pp 22-29. J. Bryan Page in "The children of exile: relationships between the acculturation process and drug use among cuban youth," Youth and Society, June 1980, pp 431-437," applies a cultural background to his study of drug use by Cuban-American youths, the not uncommon incidence of this behavior lies at the heart of the article.

13 Inquiry, pp 18-21.

14 Jo Thomas, "Nicaraguans train in Florida as Guerrillas," New York Times, 17 March 1981, p A14, Alpha 66 figures prominently in this version of the Contra training camps; Jeff Stein, "Guerrillas in gringoland." Rolling stone, 14 May 1981, pp 16+; Ronnie Lovler, "Training for the Counterrevolution," The Nation, 26 September 1981, pp 265-268; "Inside Camp Cuba-Nicaragua," Time, 8 February 1982, p 34 ; "Terrorism in Miami: Suppressing Free Speech." Counterspy, March-May 1984, pp 26+. See Frances FitzGerald, "Annals of Justice: Iran-Contra," New Yorker, 16 October 1989, pp 7584, for a discussion of Felix Rodriguez's involvement in supplying the Contras with aid. See also: Washington Post, 26 October 1986, p Al; Wall street Journal, 16 January 1987, p 1; various New York Times bibliographical references between October 1986 and January 1987; Didion, part IV. 
describe this interesting chapter of Cuban-American exile life in the United States. ${ }^{15}$

15 Michael Daly, "Los Bandidos take the town." New York, 26 October 1981, pp 67-73. Statistical evidence and other reports of Mariel criminal involvement must be taken with a good deal of caution, but the situation in New York and Miami was notable, see also Philip B. Taft, Jr., "The Cuban Crisis in Miami's Jails," Corrections Magazine, April 1982, pp 3540. Daly's mention of specialized crime tatoos receives further affirmation from a xerox in the Justice Department files which carefully explains the significance of the markings. See also "Castro's 'crime bomb' inside U.S." U.S. News and World Report, 16 January 1984, pp 27-30. The typology would not be complete without mention of alleged involvement in Angola against the efforts of their cuban countrymen, Harold Feeney, "No regrets, we'd do it again," The Nation, 19 April 1986, p 556. 